\title{
A CEMETERY OF THE GÁTA-WIESELBURG CULTURE AT NAGYCENK (WESTERN HUNGARY)
}

\author{
JÁNOS GÖMÖRI* - ESZTER MELIS** - VIKTÓRIA KISS** \\ Museum of Sopron, 6 Fő tér, H-9400 Sopron, Hungary \\ forum.museum@gmail.com \\ ** Hungarian Academy of Sciences, Research Centre for the Humanities, \\ Institute of Archaeology, \\ 4 Tóth Kálmán u., H-1097 Budapest, Hungary \\ melis.eszter@gmail.com,kiss.viktoria@btk.mta.hu
}

\begin{abstract}
The 29 individuals found in 27 graves at Nagycenk were buried there in the time period between 2000-1700 $\mathrm{BC}$, according to radiocarbon dates - i.e. at the beginning of the Middle Bronze Age in Hungary. The cemetery is of unique importance, both because of the richness of burial assemblages (altogether 30 bronze objects, 5 gold jewelries) and the scarcity of known Gáta-Wieselburg cemeteries. 15 percent of the ca. 180 burials in total, which relate to this culture in Hungary, are in this cemetery, and because of the few published burial sites, the cemetery at Nagycenk represents about one fourth of the materials published so far in the whole distribution area of the culture. Pottery style, typology and raw material of metal artefacts, as well as the radiocarbon dates (with the earliest among the published radiocarbon dates in context of this culture) support the dating of the cemetery section to the early phase of the Gáta-Wieselburg culture. The oval arrangement of burials around grave 55 and grave 1 suggest that each of these correspond to a household of high status men representing a few generations of the population living in the settlement excavated in the vicinity of Nagycenk.

Keywords: Early Bronze Age, western Hungary, Gáta-Wieselburg culture, burials, copper and bronze metallurgy, relative and absolute chronology, socio-archaeological analysis
\end{abstract}

\section{INTRODUCTION}

The area surrounding the Lake Neusiedlersee is situated in the central region of the distribution area of the Gáta-Wieselburg culture during end of the Early Bronze Age and Middle Bronze Age period (Reinecke Br A1b and A2, cca. 2100-1700/1600 BC) according to Hungarian terminology. ${ }^{1}$ The strip of land around the Hungarian part of the lake, as well as the villages - situated a little farther, near the M85 road, including for example Nagycenk -, are exceptionally rich in archaeology, which represents various ages. ${ }^{2}$ As a result of the 2004 rescue excavation at Nagycenk, a new site was put on the distribution map of the Middle Bronze Age Gáta-Wieselburg culture, extending between the River Rába and the Vienna Basin. ${ }^{3}$ Preceding a rail track correction of the Nagycenk section of the Sopron-Szombathely railway, excavations were carried out along the line of construction, to the west from the village, near the Austrian-Hungarian border, along the north side of the Arany stream. As the SW part of the site was affected by the construction of the railway track, we were able to survey only a 100 by 60 meters large area in the Lapos-rét field, extending to the NW from the bend of the stream, however, the site continued to the $\mathrm{N}$ and $\mathrm{E}$. The excavations took place in two campaigns - in accordance with the construction -, in May 2004 and between November 2004 and January 2005, during the winter months, sometimes in fairly harsh conditions. The valley of

\footnotetext{
${ }^{1}$ For the dating of the Central European Early Bronze Age and Middle Bronze Age in Hungary, see: FISCHL et al. 2013; STOCKHAMMER et al. 2015.
}

\footnotetext{
${ }^{2}$ GÖMÖRI 2012, 272-276.

${ }^{3}$ LEEB 1987; GÖMÖRI 2012, Abb. 108; NAGY 2013, Abb. 1; MeLis 2017, Fig. 1
} 
the small stream, which could have been an important traffic route since Prehistoric times, was inhabited in almost all ages, as shown by the map of archaeological sites within the present day territory of Nagycenk $($ Fig. 1$){ }^{4}$ In the southern slope of the field, which was closer to the Arany stream, and was adjacent to the soggy meadow, Lengyel culture pits were found (dating from the Late Neolithic period), ${ }^{5}$ and the outer perimeter of the Bronze Age cemetery was also found among the sunken house pits of the Árpád period $\left(12^{\text {th }} \mathrm{c}\right.$. $)$ village of Tóthczenk. ${ }^{6}$ During the excavation traces of the Bronze Age settlement were also found to the north of this cemetery, along the Arany stream. ${ }^{7}$

The 2004-2005 excavations uncovered 27 Bronze Age burials on the southern slope of the flat hill stretching along the Arany stream (Fig. 2.1). The Prehistoric burial site extended towards the top of the hill as well; however, only a part of the cemetery fell within the area of the rescue excavation. This does not allow a comprehensive study of the population, as the excavated graves represent only a segment of the community using the cemetery. Taking this into account, nonetheless, the excavation of the site is still significant, considering the few number of Gáta-Wieselburg cemeteries and the richness of the finds recovered (30 bronze objects, 5 golden jewelries). There are altogether 180 Gáta-Wieselburg burials known so far from Hungary, 15\% of which (27 burials) come from

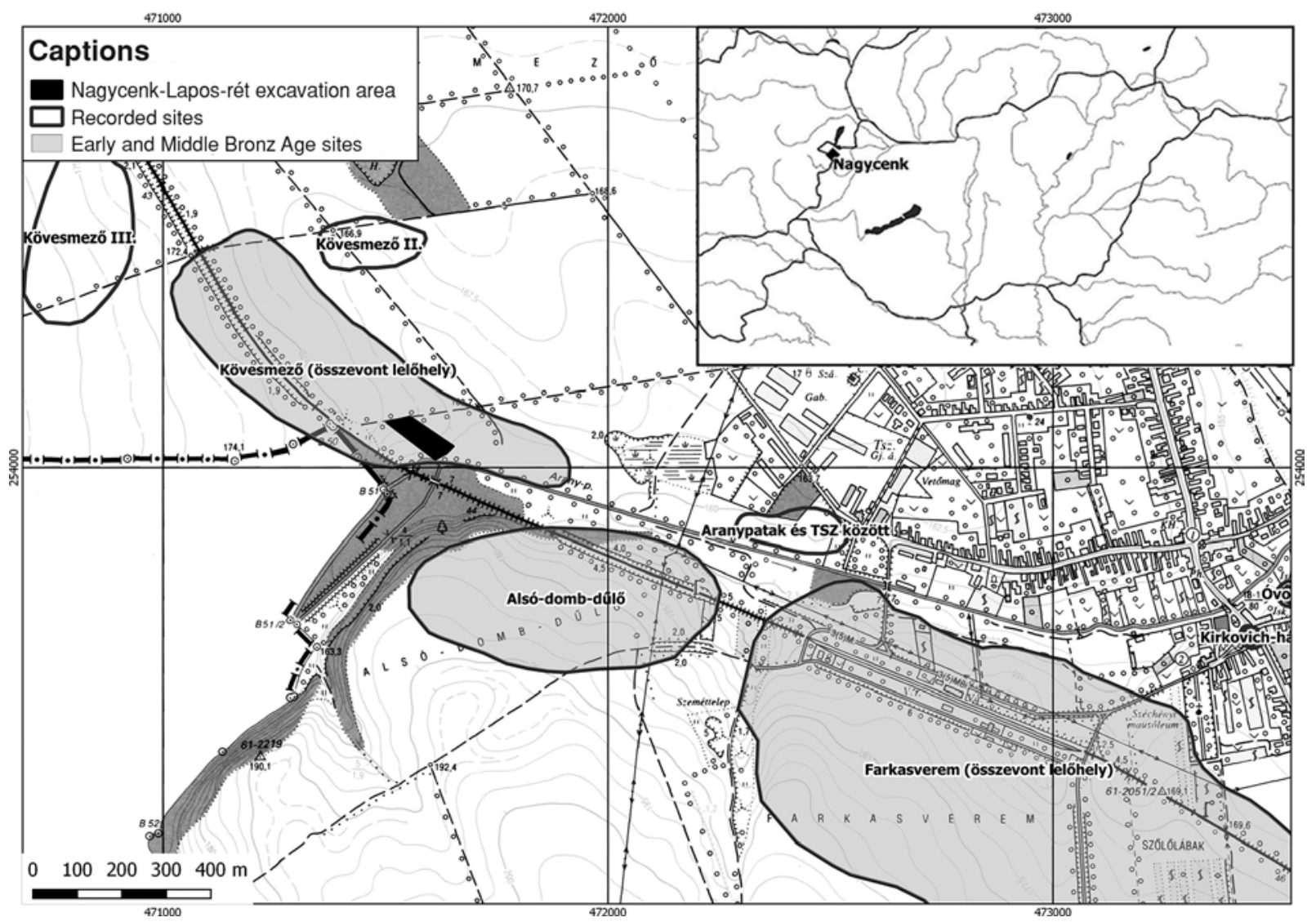

Fig. 1. Archaeological sites in the vicinity of Nagycenk based on official archaeological register, with the place of the excavated area (Lapos-rét and Kövesmező altogether under Kövesmező site name)

${ }^{4}$ For the latest review concerning archaeological sites in the area of Nagycenk as well as the excavations prior to the correction of the rail track, see: GÖMÖRI 2016, 229, Fig. 1-2. Archaeological excavations are currently underway for the M85 road, on the southern side of the Arany stream and western side of the railway, which will soon yield relevant new data on the Bronze Age research of the area. In 2018, the Momentum Mobility Research Group, at the Institute of Archaeology of the Hungarian Academy of Sciences, conducted further research (systematic field surveys and geophysical surveys) in the southern area of the Fertö Lake, as well as along the Arany stream.
${ }^{5}$ GÖMÖRI 2007; GÖMÖRI 2011.

${ }^{6}$ GÖMÖRI 2016.

${ }^{7}$ Located along the old course of the Arany stream (before corrections). Map projection: EOV, Page numbers: 61-221, 61-222. P: 50, X: 254 030, Y: 471 780, m a.s.1.: 162,5. Parcel number: 07/11, 019/4 (2004). Rescue excavation by J. Gömöri: 27. 10. 2004.-24. 03. 2005. Prehistoric pits and scattered ceramic sherds were found in the trenches prior to excavating the new course of the stream: SM Archaeological Archives 848. Materials from the Bronze Age settlement are being assessed by Eszter Melis. 


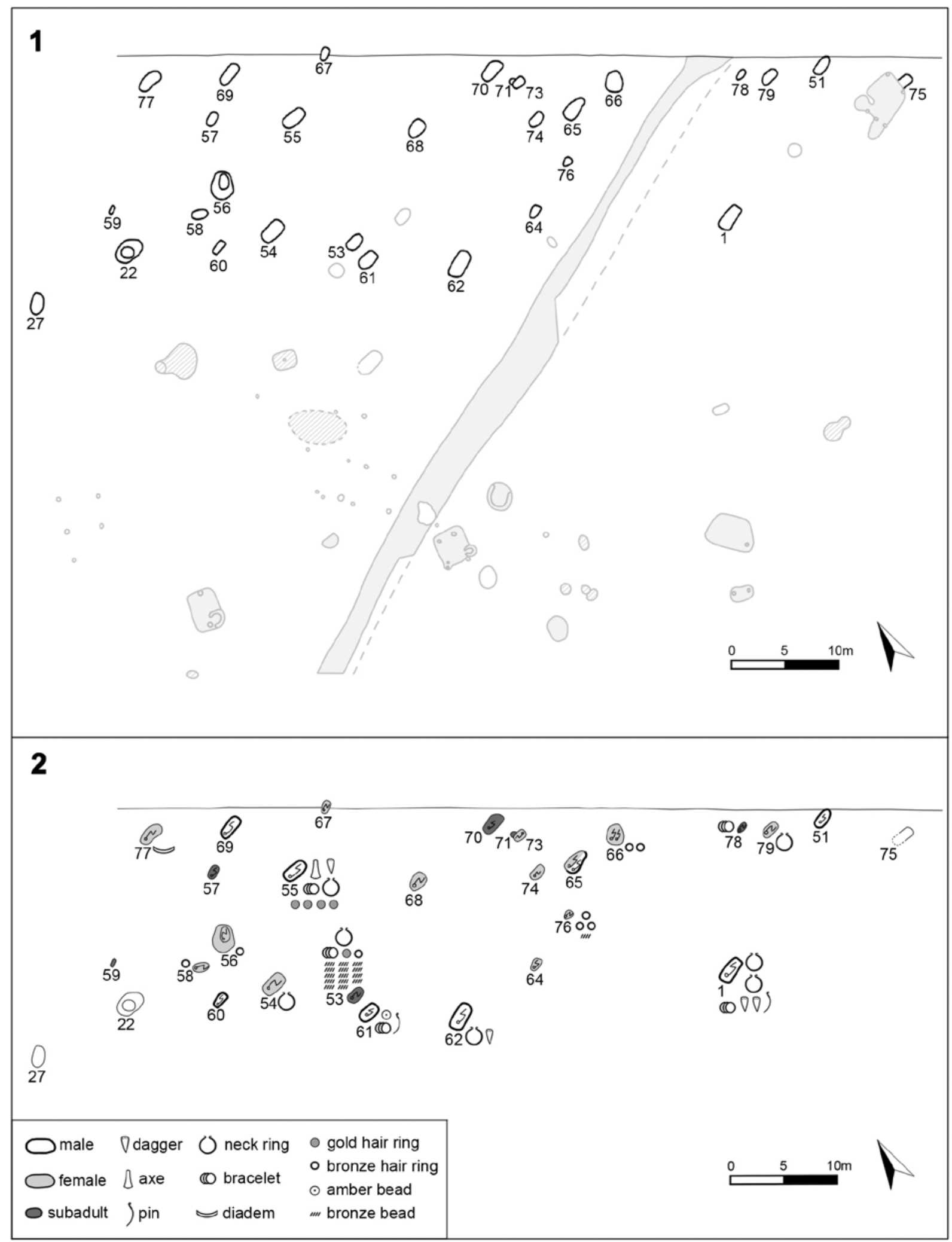

Fig. 2. 1. Nagycenk-Lapos-rét (2004-2005) excavation map (black: features of the Bronze Age, grey: Neolithic and Arpad period features); 2. Bronze Age burials with determined sex and metal grave goods 
Nagycenk, and there are approximately another 1000 of them known from Austria. ${ }^{8}$ Yet, there have been only a few of them published: approximately 20 graves from Hainburg-Teichtal, ${ }^{9} 36$ graves from Bratislava-Rusovce (Oroszvár; in separate publications), ${ }^{10}$ barrows with burials of more periods in Jois (Nyulas) and Oggau (Oka), one and two graves from Szeleste and Hegyeshalom respectively. ${ }^{11}$ There is but only one cemetery fully published recently, from Zsennye (yet, out of the 24 graves there were only 13 with human bones materials). ${ }^{12}$ Thus, the burials in Nagycenk represents about one fourth of the materials published so far. The present discussion relies on Zsuzsanna Zoffmann's results with regard to anthropological assessment of human remains (29 skeletons were found in the graves). ${ }^{13}$

\section{GRAVES AND GRAVE GOODS}

Grave 1 (Fig. 3-4)

Grave-pit: at $-38 \mathrm{~cm}$, oval shaped pit, boundaries were visible on the scraped surface. It was dug into the clayey-pebbly soil, and the pit fill contained a lot of charcoal and dark grey soil. 7-12 cm below the scraped/cleaned surface (and $28 \mathrm{~cm}$ above the skeleton) remains of charred wooden planks were detected. This layer - only $2-10 \mathrm{~cm}$ above the humeri - was the trace of either a flat wooden cover panel assembled of planks (supported by bulks on the two sides of the grave), or a coffin.

Dimensions: Length: $240 \mathrm{~cm}$, Width: $70 \mathrm{~cm}$ to the South, $112 \mathrm{~cm}$ to the North; Depth: $15 \mathrm{~cm}$

Orientation: WSW-ENE

Human remains: Poorly preserved skeleton, laid supine, right lower arm resting on the chest, the left one pulled up to the left shoulder. Legs bent at knees, slightly pulled up and turned to the left, in a semi-flexed position. The shin bones were found at the end of the pit, when removing the charred wooden layer.

Orientation of the skeleton: W-E

Anthropological description: 23-28 years old, male

Grave inventory:

1. Copper ${ }^{14}$ Cypriot pin (Schleifenkopfnadel), found at the left shoulder, with a thin wire wrapped 11 times around the neck of the pin. Length: $17 \mathrm{~cm}$, Thickness: $0.2 \mathrm{~cm}$, Weight: $15 \mathrm{~g}$ (Fig. 3.1.1)

2. Copper neck ring (Ösenhalsring) with flattened and rolled ends, and round cross-section, found at the right shoulder. Diameter: $17 \mathrm{~cm}$, Thickness: $0.7 \mathrm{~cm}$, Weight: $121.3 \mathrm{~g}$ (Fig. 3.1.2). Two samples were taken by drilling from the part with maximum width. ${ }^{15}$

3. Copper neck ring (Ösenhalsring) with rolled ends. Similar to no. 2, but the ends are more open. Placed above find no. 2 . Diameter: $16.2 \mathrm{~cm}$, Weight: $137.6 \mathrm{~g}$ (Fig. 4.1.3)

4. Copper arm spiral made of an oval cross-section band with 10-turns. Found at the right lower arm. Both ends are broken. Length: $7 \mathrm{~cm}$, Thickness: $0.5 \mathrm{~cm}$, Width: $6.3 \mathrm{~cm}$, Weight: cca. $160 \mathrm{~g}$ (measured with the supporting paper roll: $168 \mathrm{~g}$ ) (Fig. 4.1.4)

5. Copper dagger, with curved blade, thickened in the middle, and with rounded triangular handle fastened to the blade with three square-sectioned rivets, found at the left elbow. The broken edges of the handle, as well as two fragmented rivet holes indicated that the weapon had been repaired. Its asymmetric shape suggests re-sharpening. The organic handle left a curved mark on the blade. Length: $11 \mathrm{~cm}$, Width: $4.5 \mathrm{~cm}$, Length of rivets: $0.7 \mathrm{~cm}, 0.9 \mathrm{~cm}, 1 \mathrm{~cm}$ Weight: $29.3 \mathrm{~g}$ (without the rivets: $28 \mathrm{~g}$ ). In the middle part two samples were taken by drilling. ${ }^{16}$ (Fig. 4.1 .5 )

6. Small copper dagger with three rivets, found below the other one (no. 5). Two square sectioned rivets were found in situ and were collected. The middle one was longer, and it was found in secondary position. Length: $8.1 \mathrm{~cm}$, Width: $3.5 \mathrm{~cm}$, Length of rivets: $0.8 \mathrm{~cm}, 1 \mathrm{~cm}, 1.5 \mathrm{~cm}$, Weight: $20.9 \mathrm{~g}$ (without the rivets: $19.9 \mathrm{~g}$ ) (Fig. 4.1.6) Three samples were taken by drilling from the middle part. ${ }^{17}$

7. Deep bowl, found at the left side of the skull, with slightly everted rim and spherical shape. It is dark grey and burnished on the inside and outside, originally with three strap handles from the rim to the shoulder. Diameter at the rim: $22 \mathrm{~cm}$, Height: $9 \mathrm{~cm}$ (complete), Thickness: 0.4 cm (Fig. 4.1.7)

\footnotetext{
${ }^{8}$ Krenn-Leeb 2011a; Krenn-Leeb 2011b; SAUer et al. 2012, SAUER et al. 2013; FranZ et al. 2014; Melis 2017, 8-10.

${ }^{9}$ BENINGER et al. 1930; finds from the cemetery (320 graves in total) are being assessed by Alexandra Krenn-Leeb (KRENNLEEB 2011a).

${ }^{10}$ KÖSZEGI 1958; BóNA 1975, 237-239; PiChLEROVÁ 1980;

BAZOVSKÝ-ŠEFČÁKOVÁ 1996; BARTíK et al. 2016

${ }^{11}$ HicKe 1987; NAGY-FigLER 2009, 257-261.

${ }^{12}$ NAGY 2013.

${ }^{13}$ Zsuzsanna Zoffmann published the anthropological analyses of 27 (28?) individuals from 26 graves (ZoFFMANN 2008).

Acta Archaeologica Academiae Scientiarum Hungaricae 69, 2018
}

During her recent analyses, Kitti Köhler completed the list of individuals to 29 , by identifying more parts of the child from Grave 66 and also human bone remains from the Árpád Age settlement feature 50, that belong to disturbed Grave 75 .

${ }^{14}$ Good condition metal finds were examined by pXRF, thanks to Boglárka Maróti's help, so in several cases we could identify copper and bronze artefacts.

${ }^{15}$ Sampling by Ernst Pernicka (2005).

${ }^{16}$ See note 15 .

${ }^{17}$ See note 15. 


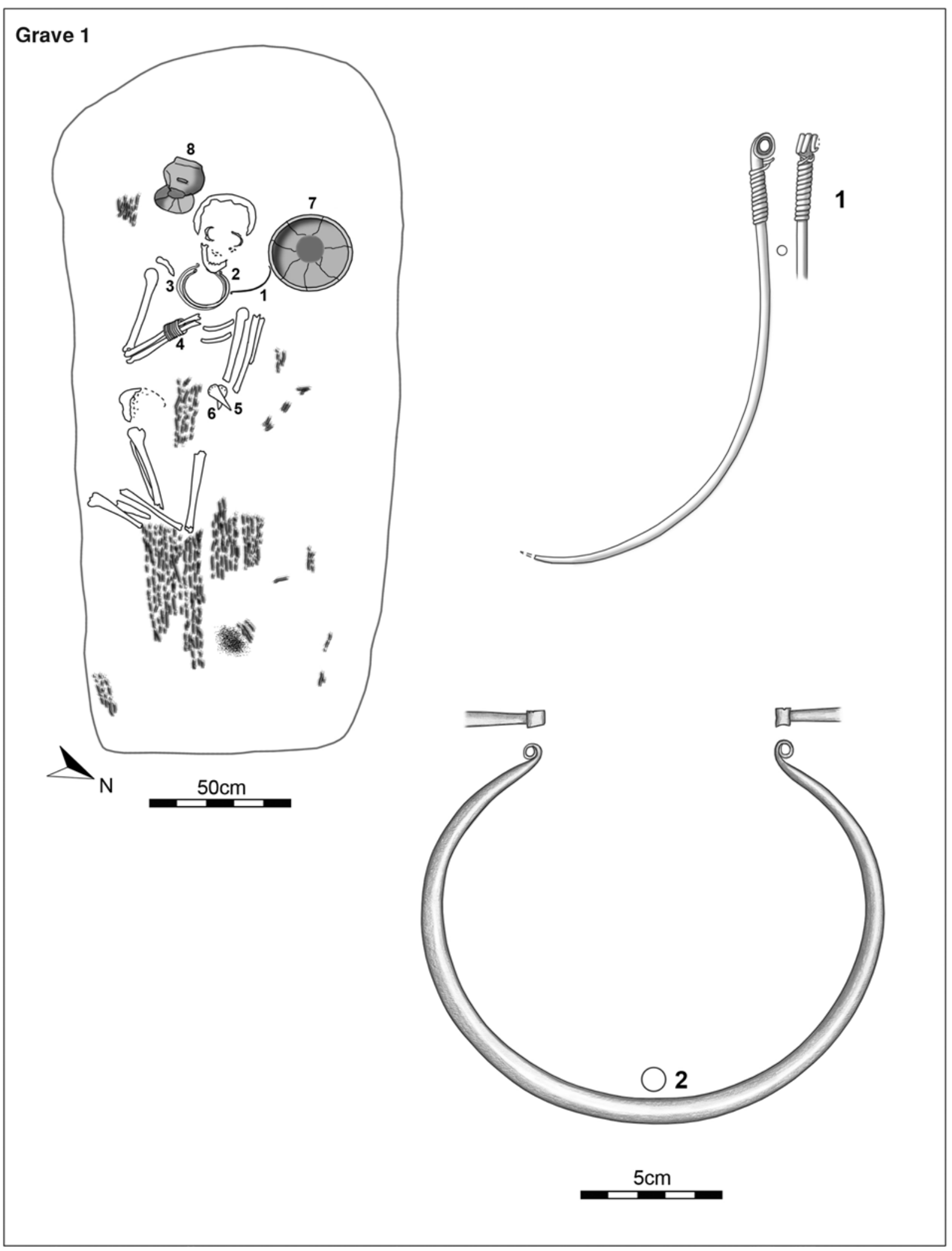

Fig. 3. Nagycenk-Lapos-rét, grave 1 
8. Double-handled jug, found at the right side of the skull, on a slightly higher level, with its mouth pointed towards east. It is spotted gray, burnished, and has funnel shaped neck, slightly stout, biconical shape, with two hour-glass shaped handles from the rim to the upper part of the vessel. A triangular sectioned rib applied around the bottom of the neck. Slightly visible irregular incisions can be seen below the handles. Diameter at the rim: $12 \mathrm{~cm}$, Heighth: $14.5 \mathrm{~cm}$, Diameter of the base: $6 \mathrm{~cm}$, Thickness: 0.5-0.6 cm (Fig. 4.1.8)

9. A rim sherd, decorated with a rib and with finger impressions on the coarse surface of the neck, was found in the fill. Its original position could not be ascertained. Reddish-brown colour, rough ware. The rim is diagonally cut. Height: $2.9 \mathrm{~cm}$, Thickness: $0.6 \mathrm{~cm}$ (Fig. 4.1.9)

\section{Grave 51 (Fig. 5.51)}

Grave-pit: a discoloration, slightly protruding into the area of the excavation has been scraped expanding the trench with the machine and revealing the grave-pit.

Dimensions: Length: $170 \mathrm{~cm}$, Width: $85 \mathrm{~cm}$, Depth: $10 \mathrm{~cm}$

Orientation: WSW-ENE

Human remains: Robust, well preserved skeleton, with a skull turned left, looking north. Upper body in supine position, left arm is next to the body, with the hands pulled to the shoulder, or to the face. The right lower arm is placed on the left upper arm. The pelvis is in front, both legs are bent at knees, moderately pulled up on the left side.

Orientation of the skeleton: W-E

Anthropological description: $36-42$ years old, male

Grave inventory:

1. Double-handled, dark grey jug, found at the right shoulder. It has everted rim, curved, funnel shaped neck, stout body, wide shape, and burnished surface outside and on the inside of the neck. Two slim, hour-glass shaped handles starting from the rim, and attached to the upper part of the body. There is a slightly raised rib around the neck, and there are two straight parallel horizontal incisions running around the body, below the handles. Diameter at the rim: $12 \mathrm{~cm}$, Height: $15 \mathrm{~cm}$, Diameter at the base: $6 \mathrm{~cm}$, Thickness: $0.4 \mathrm{~cm}$ (Fig. 5.51 .1$)$

2. Deep bowl, found at the left elbow, with light grey colour, and worn burnishing. It has everted rim, curved, funnel shape neck, reverse truncated cone-shaped body, with pointed shoulders. It is restored on one side. There were originally four knobs on the shoulder, all of them had oval shapes, and each had one or two vertical holes. Of the third one, only a fragment remained. Diameter at the rim: $20 \mathrm{~cm}$, Depth: $10 \mathrm{~cm}$, Diameter at the base: $6.5 \mathrm{~cm}$, Thickness: $0.4 \mathrm{~cm}$ (Fig. 5.51 .2 )

Grave 53 (Fig. 5.53)

Grave-pit: Oblong, with rounded corners.

Dimensions: Length: $170 \mathrm{~cm}$, Width: 73-105 cm, Depth: $17 \mathrm{~cm}$

Orientation: WSW-ENE

Human remains: poorly preserved skeletal remains; most of the ribs and the spinal vertebrae were decayed, and the ends of the arm and leg bones as well. Skull is tilted to the right, facing south. One arm is pulled up to the skull. Legs are moderately pulled up to the right side.

Orientation of the skeleton: W-E

Anthropological description: 10-12 years old, (infans II)

Grave inventory:

1. There is a gold wire hair ring (Noppenring) on the left temple. Diameter: $1.3 \mathrm{~cm}$, Weight: $2 \mathrm{~g}$ (Fig. 5.53.1)

2. Slightly square sectioned, thin, bronze neck ring with rolled ends (Ösenhalsring). One end is broken off. Diameter: $9.5-10 \mathrm{~cm}$, Thickness: $0.3 \mathrm{~cm}$, Weight: $15.7 \mathrm{~g}$ (Fig. 5.53.2)

3-4. To the west of the skull, at the edge of pit, there were three tiny copper or bronze spiral beads found, a few centimeters higher than the skull. They were placed in the grave perhaps separately from the body, however, possible bioturbation cannot be ruled out. Twenty bronze spiral tubes (arranged in two rows) were found around the neck, preserved in corroded state ( 16 of them were ca 1.5-2 cm long originally). Diameter: $0.5 \mathrm{~cm}$, weight of: $0.1 \mathrm{~cm}$ (of the wire) Length: $1.5-2 \mathrm{~cm}$, Weight (measured together with the line): 13 pcs: $16.7 \mathrm{~g}$; spiral bead fragments (77 pcs): 8 g. (Fig. 5.53.3-4) The two necklaces originally were held together by tube shaped shells of snails - of the species Anatalis (dentalium) Quindeciess Triata, however, after restoration these are not present among the grave goods.

5. Bronze ring (Noppenring). Found near to one of the fingers, which was placed close to the skull. Damaged during the excavation. Diameter: ca. $1.8 \mathrm{~cm}$, Thickness: ca. $1 \mathrm{~mm}$ thick wire; Weight: $0.5 \mathrm{~g}$ (Fig. 5.53.5)

6. Copper or bronze spiral arm ring, poorly preserved, found on the left lower arm, which was pulled up to the skull. Square-sectioned wire, both ends were broken off. Diameter: $4 \mathrm{~cm}$, Thickness: $0.2 \mathrm{~cm}$, Weight: $13.7 \mathrm{~g}$ (Fig. 5.53.6) 


\section{Grave 1}
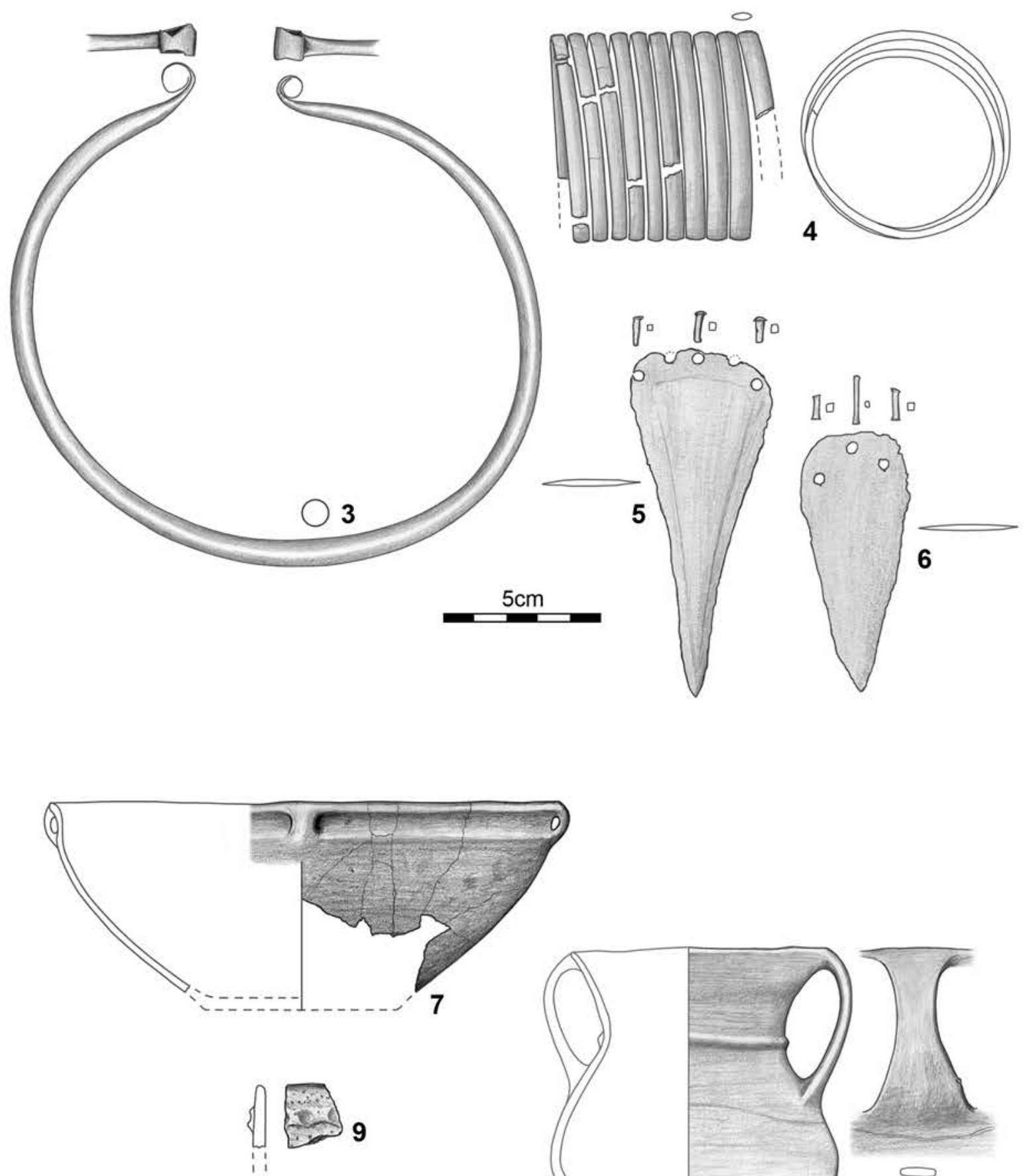

$5 \mathrm{~cm}$

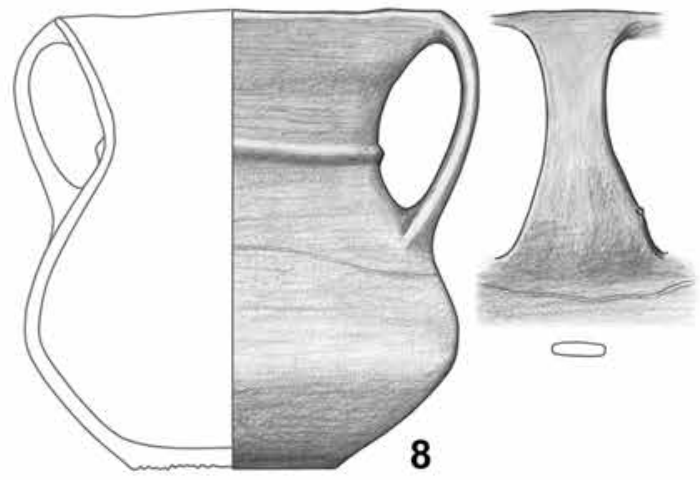

Fig. 4. Nagycenk-Lapos-rét, grave 
7. Deep bowl, found at the foot. It is brownish grey, burnished, and has everted rim, funnel shaped neck, and pointed shoulder. Diameter: $25 \mathrm{~cm}$, Height: $6.5 \mathrm{~cm}$, Thickness: $0.4 \mathrm{~cm}$ (Fig. 5.53.7)

8. Single handled jar, placed inside the bowl, which was placed at the feet. It is dark grey, with light brown stains. It is burnished, and has pronouncedly funnel-shaped neck, with a handle below the rim, applied to the upper part of the ovoid belly. Diameter at the rim: $10.5 \mathrm{~cm} ; \mathrm{Height}$ : $8.5 \mathrm{~cm}$; Diameter at the base: $5 \mathrm{~cm}$; Thickness: $0.5 \mathrm{~cm}$ (Fig. 5.53.8)

\section{Grave 54 (Fig. 6-7)}

Grave-pit: relatively large and deep, with vertical walls. At the west end, piled up above the skull, there were the remains of at least three vessels. Dimensions: Length: $240 \mathrm{~cm}$, Width: $120 \mathrm{~cm}$, Depth: $75 \mathrm{~cm}$

Orientation: WSW-ENE

Human remains: the skull was found at $-70 \mathrm{~cm}$, together with a neck ring. The upper part of the body is laid prone, while the body was crouched on its right side; the skull is looking south. Both arms were tightly flexed in front of the face. Legs were tightly pulled up.

Orientation of the skeleton: W-E

Anthropological description: $44-50$ years old, female

Grave inventory:

1. Copper neck ring (Ösenhalsring) with rolled ends. Diameter: $16.3 \mathrm{~cm}$, Thickness (max): $1 \mathrm{~cm}$, Weight: $179 \mathrm{~g}$ (Fig. 6.54.1)

2. Behind the skull fragments of a large vessel were found. Following restoration, it turned out to be an amphora, with assymetric handle. It is reddish brown, with grey stains, and burnished surface. It has everted rim, funnel neck, wide biconical body, and two long handles, applied from the rim (or a bit below) to the upper part of the belly. There is also a round shaped strap handle applied to the upper part of the vessel. On the reverse side there is a swallowtail shaped applique decoration. There are two parallel incisions running around, below the handles. Diameter at the rim: $20.5 \mathrm{~cm}$, Height (reconstructed): $26.5 \mathrm{~cm}$, Diameter at the base: $10 \mathrm{~cm}$, Thickness: $0.6 \mathrm{~cm}$ (Fig. 7.54 .2 two views of the vessel)

3. Above the fragments of no. 2, a single-handled pot was found. It is grey, with reddish-brown stains, burnished. If has everted rim, smoothed shoulders, ovoid body. Its mouth was facing west. The fragment of a strap handle remained on the shoulder. Traces of smoothing is visible on the upper part of the belly. Diameter at the rim: $14.5 \mathrm{~cm}$; Height: $14 \mathrm{~cm}$, Diameter at the base: $7.5 \mathrm{~cm}$; Thickness: $0.6 \mathrm{~cm}$ (Fig. 6.54.3)

4. Small, single-handled pot was found to the south of find no. 2, with its mouth facing east. It is grey, and reddish brown, burnished. It has everted rim, funnel neck, biconical body. Applied to the bottom of the neck, there were three elongated knobs and the lower fragment of a small strap handle. Decorated with a band of three, irregular incised lines, running around the neck and the knobs. Diameter at the rim: $14 \mathrm{~cm}, \mathrm{Height}$ : $13 \mathrm{~cm}$, Diameter at the base: $7 \mathrm{~cm}$, Thickness: $0.5 \mathrm{~cm}$ (Fig. 6.54.4)

5. Small, single-handled jar. Found during conservation, among the fragments of find no. 2. It is reddish brown, with grey stains, and rough texture. It has everted rim, smoothed shoulder, and ovoid body. Diameter at the rim: $7 \mathrm{~cm}$, Height: $10 \mathrm{~cm}$, Diameter at the base: $5.5 \mathrm{~cm}$, Thickness: $0.6 \mathrm{~cm}$ (Fig. 6.54.5)

Other fragments of small vessels, in the piles behind the skull:

6. Fragments of a jug/cup. It has funnel neck, and everted rim. Diameter at the rim: $12 \mathrm{~cm}$, Height: $4 \mathrm{~cm}$, Thickness: $0.4 \mathrm{~cm}$ (Fig. 6.54.6)

7. Fragment from the upper body of a single-handled pot. Height: $3.8 \mathrm{~cm}$, Width: $5.5 \mathrm{~cm}$, Thickness: $0.6 \mathrm{~cm}$ (Fig. 6.54.7)

8. Rim of a thick-walled vessel. Width: $3.5 \mathrm{~cm}$, Thickness: $1 \mathrm{~cm}$ (Fig. 6.54.8)

\section{Grave 55 (Fig. 8-9)}

Grave-pit: compared to the full length of the crouched skeleton $(\mathrm{ca} .90 \mathrm{~cm}$ ) it is considerably large, it has rounded corners and straight walls, filled with brown earth. The lighter coloured streaks at the skull, and along the side of the grave-pit possibly indicate bioturbation.

Dimensions: Length: $225 \mathrm{~cm}$, Width: $130 \mathrm{~cm}$, Depth: $92 \mathrm{~cm}$

Orientation: W-E

Human remains: Skeleton is laid on its right side, upper body in prone position, tightly flexed arms in front of the body.

Orientation of the skeleton: W-E

Anthropological description: $37-46$ years old, male

Grave inventory:

1. Flanged bronze axe (Randleistenbeil), found on the right side of the upper body. The place of the handle was also visible due to rotted wood remains. Length: $12.3 \mathrm{~cm}$, Width: at the neck $0.8 \mathrm{~cm}$, at the edge $4.5 \mathrm{~cm}$. Weight: $162.6 \mathrm{~g}$ (Fig. 8; Fig. 9.55.1)

2. Copper, thick and round-sectioned neck ring (Ösenhalsring), found on the lower jaw. Diameter: $14.7 \mathrm{~cm}$, Max. thickness: $1 \mathrm{~cm}$, Weight: 177.5 g (Fig. 9.55.2)

3. Bronze arm ring, in a 5-turn spiral and with both ends narrowed down, found on the left arm, part of it was underneath the skeleton. Diameter: $6.5 \mathrm{~cm}$, Thickness: $12.4 \mathrm{~cm}$ (winded up from a $0.4 \mathrm{~cm}$ thick wire), Weight: $106.7 \mathrm{~g}$ (Fig. 9.55.3) 


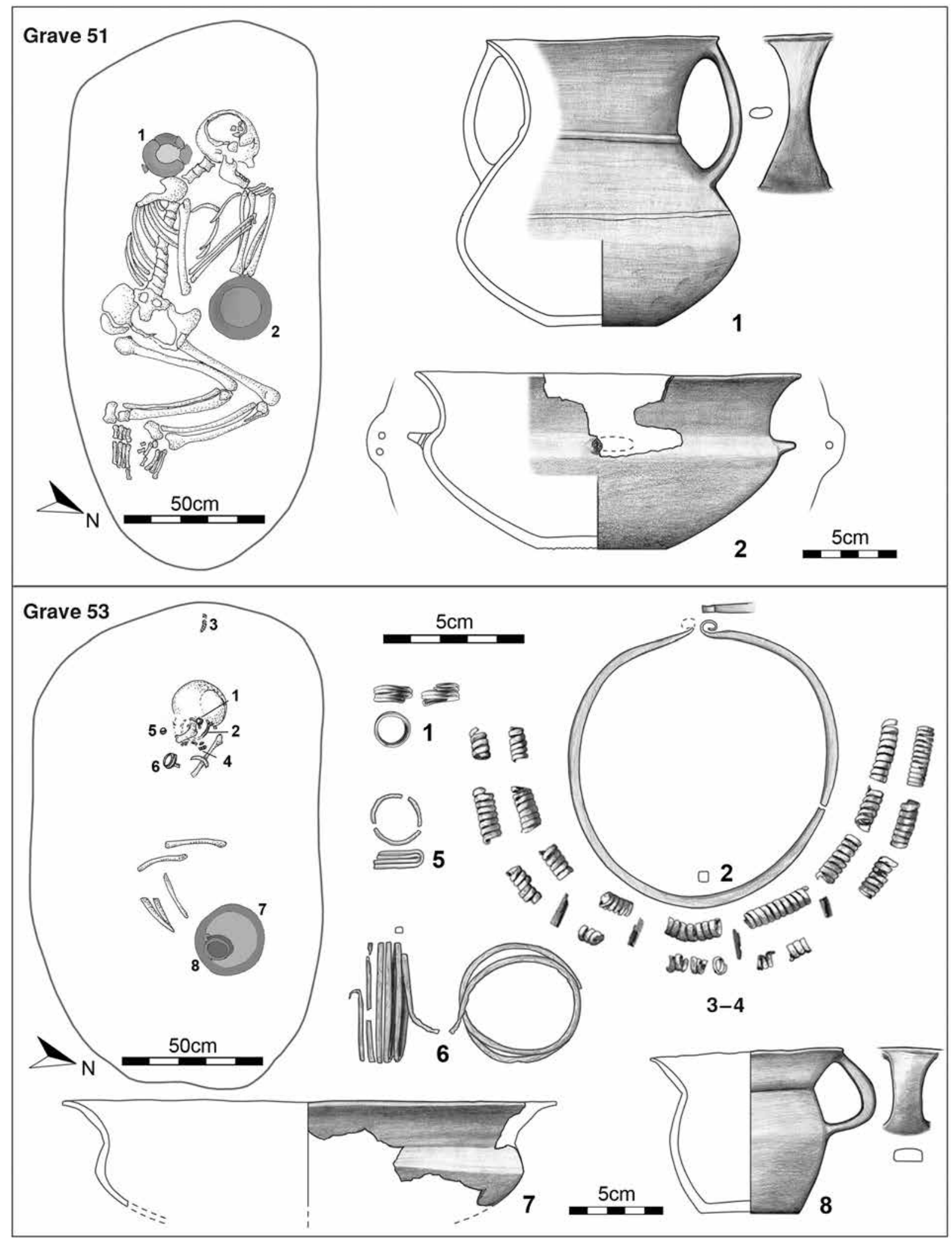

Fig. 5. Nagycenk-Lapos-rét, grave 51, grave 53 
4. Double-handled jug, found behind the skull. It has everted rim, funnel neck, stout, globular body, and a shallow base ring. Its surface is burnished, the upper part of the vessel decorated with a band of three incised lines running around, and there is also the fragment of a shallow rib around the lower part of the neck. Diameter at the rim: $10 \mathrm{~cm}$, Height (reconstructed): $12.5 \mathrm{~cm}$, Diameter at the base: $5 \mathrm{~cm}$, Thickness: $0.5 \mathrm{~cm}$ (Fig. 9.55.4)

5. Chipped stone micro blade tool at the right side of the skull with trapezoid cross-section. Its right point is curved both at the distal and the proximal sides, resulted in a half crescent shape, with no bulbus and talon. The raw material is Szentgál radiolarit. Length: $1.743 \mathrm{~cm}$, Width: $0.831 \mathrm{~cm}$, Thickness: $0.301 \mathrm{~cm}$ (Fig. 9.55.5) ${ }^{18}$

6. Bronze dagger with triangular blade and two rivets, found underneath the ribs, on the left side, at the left arm. The edge of the hilt plate is broken, and the three fragmented holes of former rivets show repairing. Traces of brown wood (or leather) sheath was also visible. Length: $11.2 \mathrm{~cm}$, Maximum width: $4.2 \mathrm{~cm}$, Weight: $27.2 \mathrm{~g}$ (without the two rivets: $27 \mathrm{~g}$ ) (Fig. 9.55.6)

7. Small, solid gold hair ring, with bent and swollen tripartite ends, found when removing the skull. Diameter: $1.2 \mathrm{~cm}$; Width (of the folded part): $1 \mathrm{~cm}$, Weight: $2.3 \mathrm{~g}$ (Fig. 9.55.7)

8. Large, solid gold hair ring, with bent tripartite ends, found when removing the skull (below find no. 7); Diameter: $1.5 \mathrm{~cm}$; Width (of the folded part): $1 \mathrm{~cm}$, Weight: $5.3 \mathrm{~g}$ (Fig. 9.55.8)

9. Gold hair ring with bent tripartite ends, found by the restorator when cleaning the skull. Diameter: $0.9 \mathrm{~cm}$, Width (of the folded part): $0.7 \mathrm{~cm}$, Weight: 2.2 g (Fig. 9.55.9)

10. Gold hair ring with bent tripartite ends, found by the restorator when cleaning the skull. Diameter: $1.3 \mathrm{~cm}$, Width (of the folded part): $1 \mathrm{~cm}$, Weight: $2.8 \mathrm{~g}$ (Fig. 9.55.10)

Mixed fragments of ceramic vessels found in the pit fill:

11. Rim sherd of a pot. Everted, decorated with finger impressions. Width: $5 \mathrm{~cm}$, Height: $4 \mathrm{~cm}$, Thickness: $1.1 \mathrm{~cm}$ (Fig. 9.55 .11 )

12. Fragments of a pot decorated with finger impressions. Height: $3 \mathrm{~cm}$, Thickness: $0.9 \mathrm{~cm}$ (Fig. 9.55.12)

13. Another chipped stone micro blade fragment was found below the skeleton. It is a proximal fragment with two ribs. It has trapezoid crosssection, with a facetted talon and small bulbus. Its left side is straight, and uneven at the mezalis. The raw material is Szentgál radiolarit. Length: $1.054 \mathrm{~cm}$, Width: $0.738 \mathrm{~cm}$, Thickness: $0.209 \mathrm{~cm}$. (Fig. 9.55.13)

Grave 56 (Fig. 10-12)

Grave-pit: large surface patch, within which there was a discoloration of a smaller pit that contained several large ceramic sherds. While bringing down the level a bit, fragments of at least four larger vessels, and other fragments were excavated. In the south part of the pit, a $25 \mathrm{~cm}$ large stone was found, which had one flat surface. When these objects were removed, the pit was excavated deeper with another $30 \mathrm{~cm}$ and there the skeleton was found in a rectangular depression (pit). South of the skull, at the end of the pit, there was another stone found, which had trapezoid shape and its size was similar to that of the above mentioned one.

Dimensions: Length: $180 \mathrm{~cm}$, Width: $90 \mathrm{~cm}$, Depth: $32 \mathrm{~cm}$

Orientation: SW-NE

Human remains: flexed position, laid on the right side, surrounded by ceramic vessels. The skull was flattened, looking southeast. Arms were flexed in front of the upper body, hands were placed below the chin, legs were moderately pulled up.

Orientation of the skeleton: SW-NE

Anthropological description: 51-57 years old, female

Grave inventory:

1. In the northeast part of the pit, in the upper layer of the fill, a double-handled amphora was found. The upper part was fragmented, burnished, and light grey colour. It has narrow funnel neck, biconical shape. In between the two handles there were three fake handles at equal distances, sitting on the upper part of the vessel, connected by a pattern of three parallel incised lines. At each fake handle there is also a vertical incision running from the neck. There is an incised shallow rib around the shoulder. Diameter at the rim: $18.5 \mathrm{~cm}$, Height: $33 \mathrm{~cm}$, Diameter at the base: $10 \mathrm{~cm}$, Width of handles: $2.8-3.8 \mathrm{~cm}$, Thickness: $0.7 \mathrm{~cm}$ (Fig. 10.56.1)

2. Single-handled pot, dark grey, found in the northeast part of the pit, in the upper layer of the fill. It has everted rim, and polished surface, decorated with a pointed knob on the lower part of the neck. Diameter at the rim: $13 \mathrm{~cm}$, Height: $13 \mathrm{~cm}$, Diameter at the base: $7.5 \mathrm{~cm}$, Thickness: $0.6 \mathrm{~cm}$ (Fig. 11.56.2)

3. Fragments of a double-handled, dark grey amphora with burnished surface, found in the northeast part of the pit, in the upper layer of the fill. It has funnel neck, biconical shape, sharp carination. Two handles are applied to the upper part of the vessel; in between them there are two small fake handles, each at approximately equal distances from the handles. At the height of the lower part of the two handles, there are two shallow,

\section{Anna Priskin}

${ }^{18}$ Descripition and drawings of the stone tools made by

Acta Archaeologica Academiae Scientiarum Hungaricae 69, 2018 


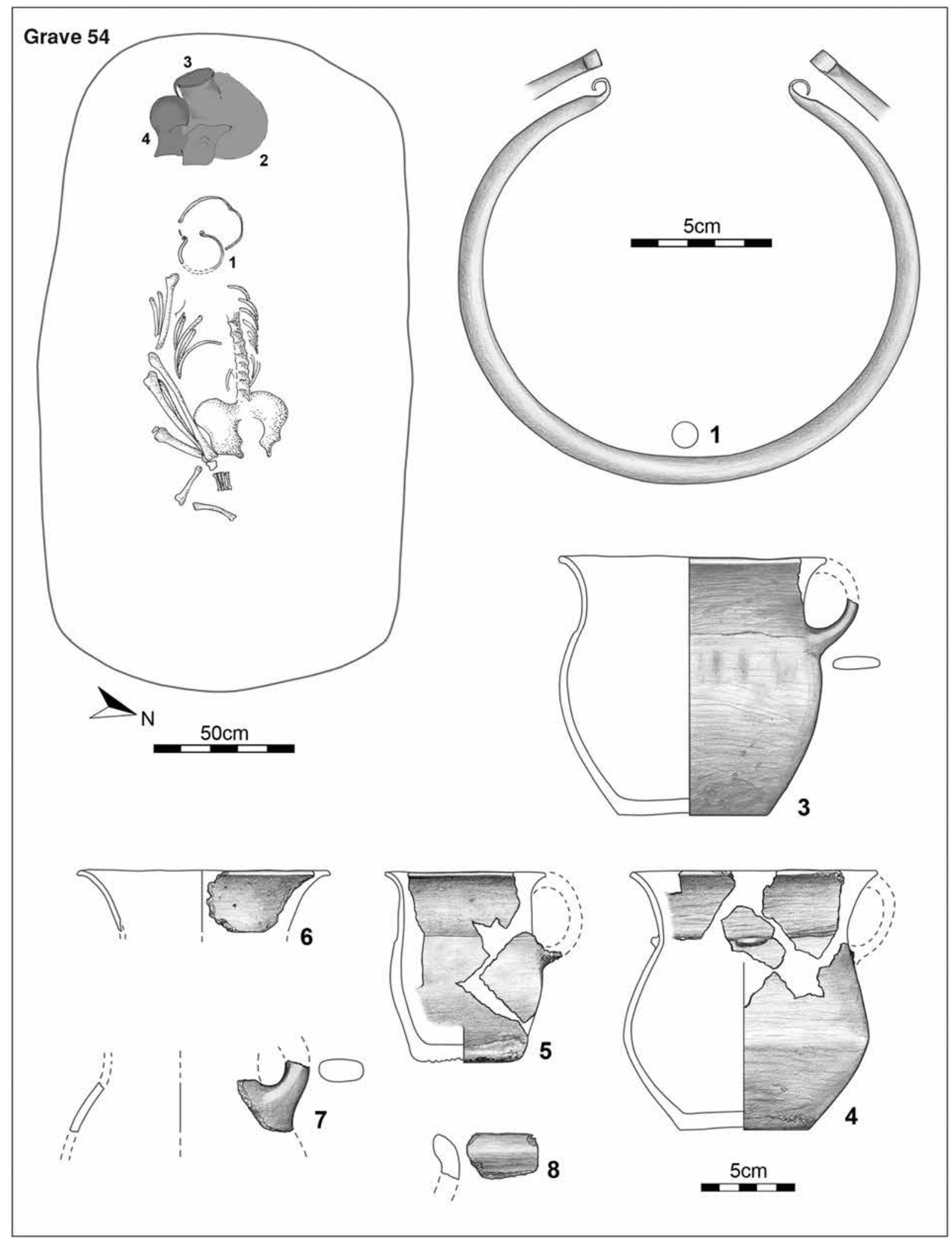

Fig. 6. Nagycenk-Lapos-rét, grave 54 


\section{Grave 54}
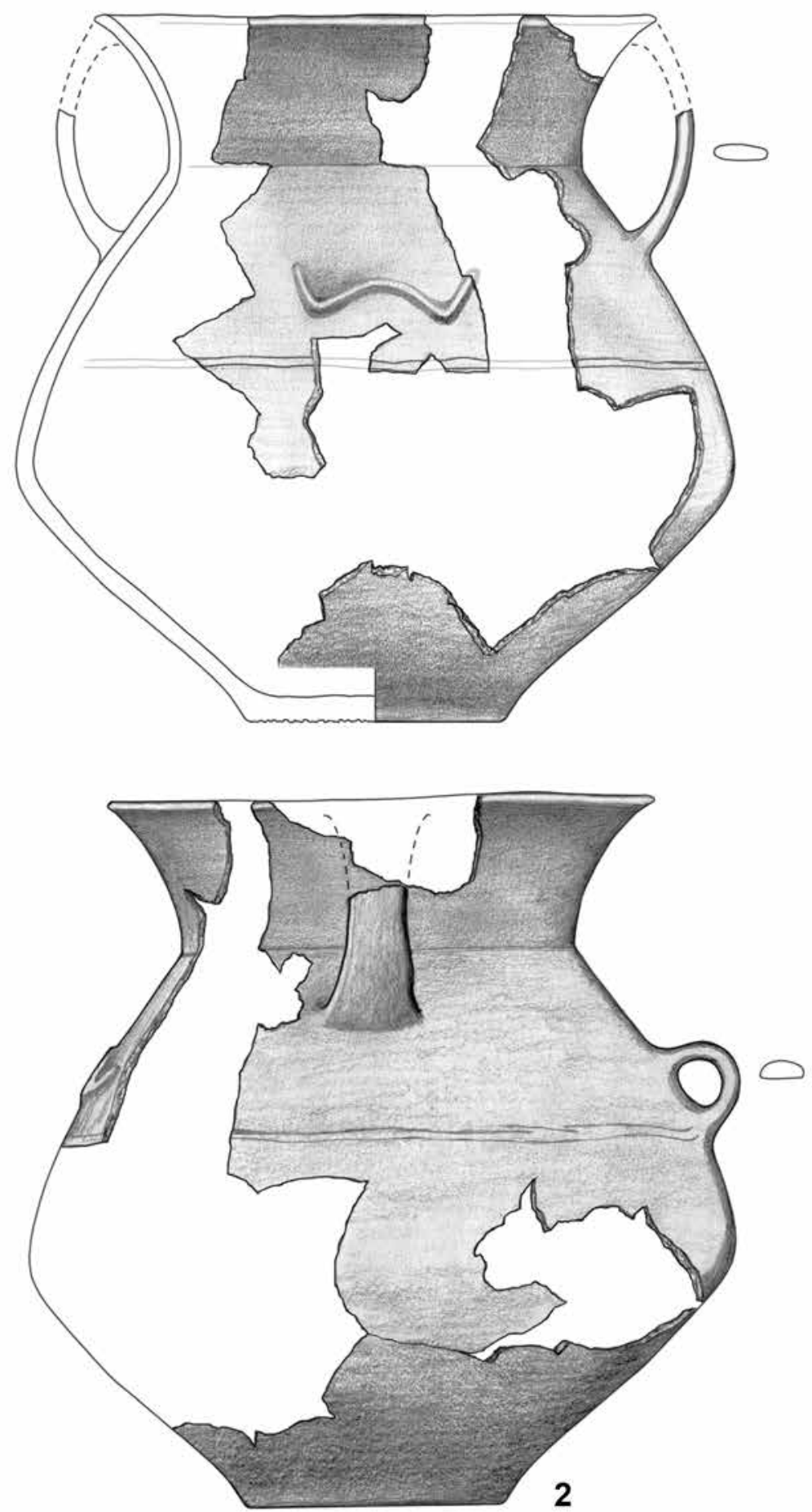

Fig. 7. Nagycenk-Lapos-rét, grave 54 


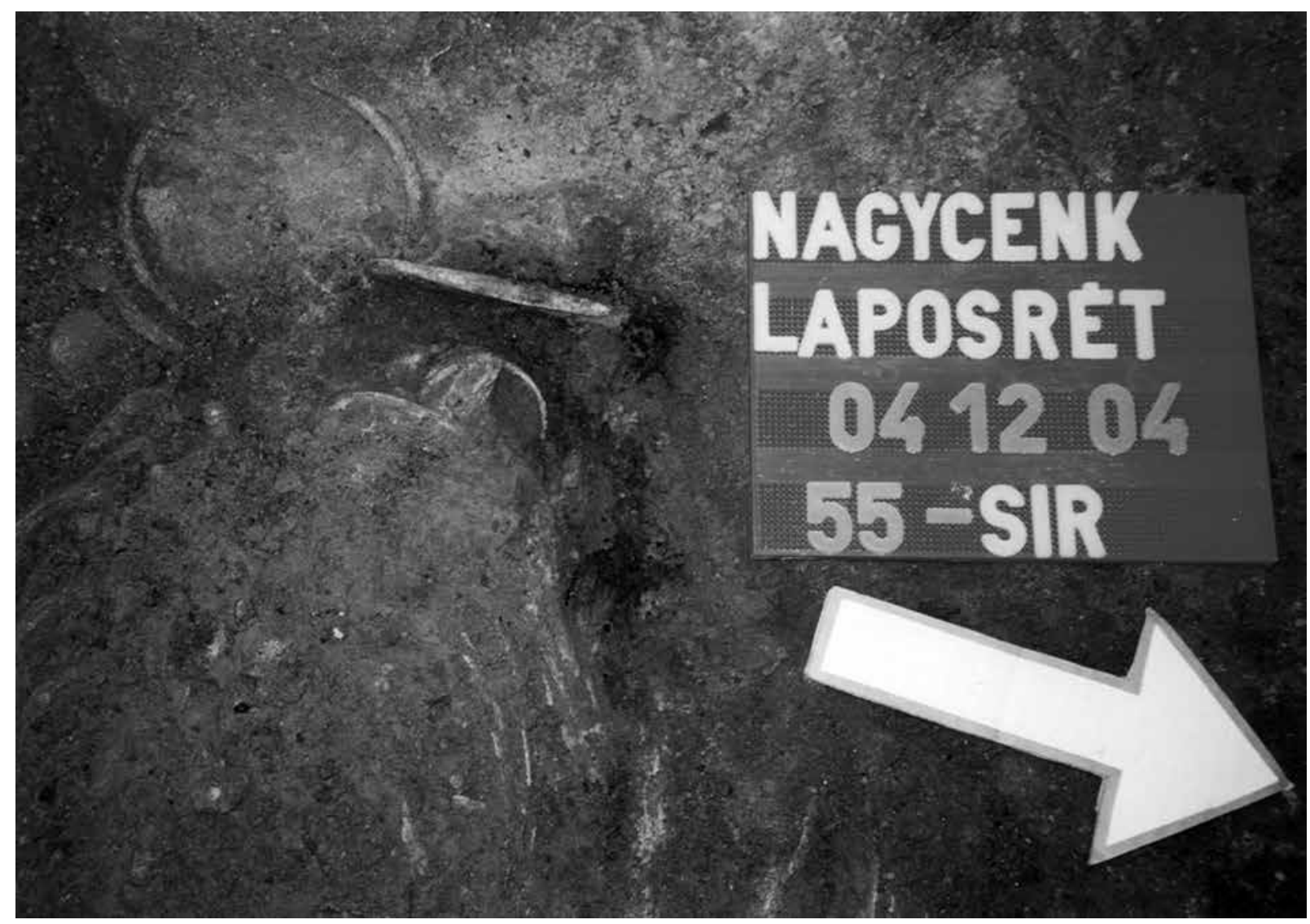

Fig. 8. Nagycenk-Lapos-rét, detailed photo of grave 55 with organic remains (photo by J. Gömöri)

but uneven incisions. The vessel has a slightly asymmetric shape, and considerably reconstructed. Diameter at the rim: $15 \mathrm{~cm}, \mathrm{Height:} 24 \mathrm{~cm}$, Diameter at the base: $9 \mathrm{~cm}$, Width of handles: $2.1-3.1 \mathrm{~cm}$, Thickness: $0.8 \mathrm{~cm}$ (Fig. 11.56.3.).

Fragments of a large double-handled, brownish grey amphora with burnished surface, found in the southwest part of the pit, in the upper layer of the fill. It has everted rim, elongated, biconical body, shallow base ring. The handle was placed below the rim, and applied to the shoulder. There is a shallow rib running around the neck and a horizontal incised line on the upper part of the vessel. Below the carination the clay surface is unevenly worked. Several fragments of this vessel were found in the lower fill of the pit, above the left arm and the upper body. Diameter at the rim: $15.5 \mathrm{~cm}$, Height: $28.5 \mathrm{~cm}$, Diameter at the base: $9.2 \mathrm{~cm}$, Thickness: $0.5 \mathrm{~cm}$ (Fig. 12.56.4,5,8)

6. Fragments of a large, grey double-handled amphora, found in the lower fill of the pit, at the right side of the skull, and at the chin. It has funnel neck, and a wide strap handle attached to below the rim and applied to the upper part of the vessel. The upper part was decorated with a few incisions, the clay of the lower part is unevenly smoothed. Diameter at the rim: $15 \mathrm{~cm}$, Height (reconstructed): $26 \mathrm{~cm}$, Diameter at the base: $10.5 \mathrm{~cm}$, Thickness: $0.6 \mathrm{~cm}$ (Fig. 12.56.6)

7. Fragments of a small handled-pot, found at the left hand. The reddish grey upper part was burnished, the lower part was gently brushed. It has everted rim, curved neck, ovoid body. There were at least two small, oval knobs at the bottom of the neck. Diameter at the rim: $9 \mathrm{~cm}$, Diameter at the base: $7 \mathrm{~cm}$, Height (reconstructed): $11 \mathrm{~cm}$, Thickness: $0.6 \mathrm{~cm}$ (Fig. 11.56.7)

9. Fragments of another grey coloured amphora, found at the left knee and at the foot. It has biconical body and sharp carination. There are two short handles on the upper part of the vessel with small fake handles in between them, connected by a shallow incision. The surface of the lower part is unevenly smoothed. Diameter at the rim: $10 \mathrm{~cm}$, Height: $21 \mathrm{~cm}$, Thickness: 0.6-0.7 cm (Fig. 12.56.9)

10. Small, dark brown and burnished, ovoid jar without handle, found northeast of the left lower leg. It has inverted, little asymmetric rim. Diameter at the rim: $5 \mathrm{~cm}$, Height: $5 \mathrm{~cm}$, Diameter at the base: $3.5 \mathrm{~cm}$, Thickness: $0.6 \mathrm{~cm}$ (Fig. 11.56.10)

11. Fragments of a reddish grey, handled-pot, found at the northwestern side of the pit. It has everted rim, curved neck, wide, biconical body, with worn burnishing on the outside. There are two oval pointed knobs on its shoulder. Diameter at the rim: $12 \mathrm{~cm}$, Height (reconstructed): 12 $\mathrm{cm}$, Diameter at the base: $7.5 \mathrm{~cm}$, Thickness: $0.7 \mathrm{~cm}$ (Fig. 11.56.11) 


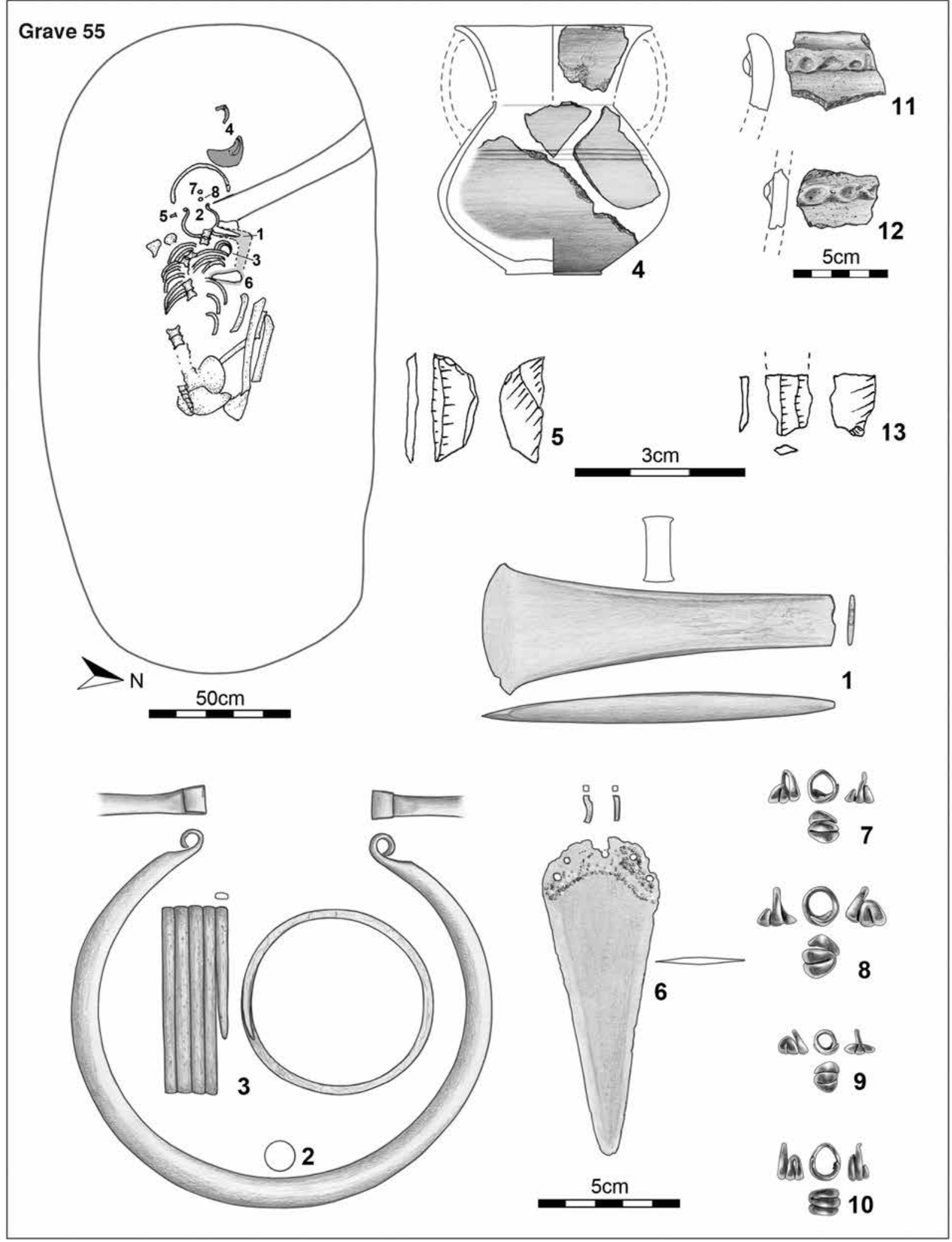

Fig. 9. Nagycenk-Lapos-rét, grave 55 


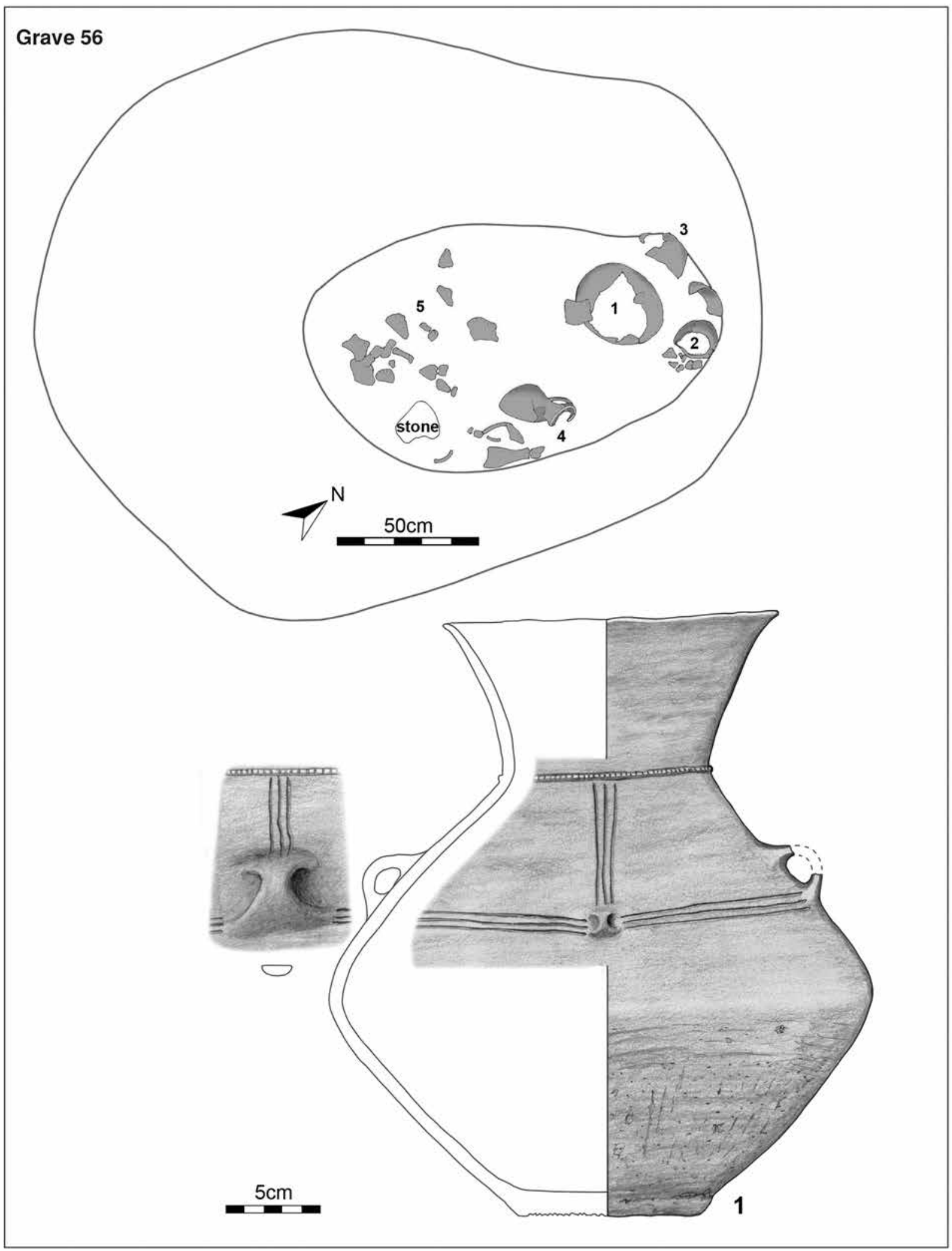

Fig. 10. Nagycenk-Lapos-rét, grave 56 
12. Possibly a fragment of no. 11

13. Copper or bronze tripartite hair ring, with solid, bent ends, found underneath the skull. The thickness of the wire is $0.2 \mathrm{~cm}$, the widening middle part and the folded parts are $0.5 \mathrm{~cm}$ thick. Weight: $4.1 \mathrm{~g}$ (Fig. 11.56.13)

Scatter finds from the fill:

14. Small spherical vessel, light brown and burnished. Diameter at the rim: $10 \mathrm{~cm}$, Height: $5 \mathrm{~cm}$, Thickness: $0.7 \mathrm{~cm}$ (Fig. 11.56.14)

15. Wall sherd, brown colour, brushed. Height: $2.8 \mathrm{~cm}$, Width: $4 \mathrm{~cm}$, Thickness: $0.7 \mathrm{~cm}$ (Fig. 11.56.15)

\section{Grave 57 (Fig. 13.57)}

Grave-pit: slightly oval shape, relatively small.

Dimensions: Length: $134 \mathrm{~cm}$, Width: $80 \mathrm{~cm}$, Depth: $32 \mathrm{~cm}$

Orientation: SW-NE

Human remains: flexed skeleton, laid on its left. Arms partially preserved, legs were moderately pulled up.

Orientation of the skeleton: SW-NE

Anthropological description: 6-7 years old, infans I

Grave inventory:

1. Cup with two handles, brownish grey and burnished, found at the left side of the skull. It has funnel neck, biconical body with carination at the lower third of the vessel. Base is slightly impressed, shaping a flat omphalos. Two hour-glass shaped, long strap handles were placed below the rim, and applied to the upper part of the vessel. Diameter at the rim: $6.6 \mathrm{~cm}$, Height: $8 \mathrm{~cm}$, Diameter at the base: $3 \mathrm{~cm}$; Thickness: $0.4 \mathrm{~cm}$ (Fig. 13.57.1)

2. Tiny fragments of a poorly preserved greyish brown, handled jar with curved profile, found at the feet. Diameter at the rime: $10 \mathrm{~cm}$, Height (reconstructed): $10 \mathrm{~cm}$, Thickness: $0.4 \mathrm{~cm}$ (Fig. 13.57.2)

\section{Grave 58 (Fig. 13.58)}

Grave-pit: oval and shallow.

Dimensions: Length: $152 \mathrm{~cm}$, Width: $89 \mathrm{~cm}$, Depth: $35 \mathrm{~cm}$

Orinetation: W-E

Human remains: moderately flexed skeleton, laid on its right, arms were flexed in front of the upper body, the hands are in front of the face. Bronze patina was observed on the jaw.

Orientation of the skeleton: W-E

Anthropological description: $32-36$ years old, female

Grave inventory:

1. Small fragments of a copper or bronze hair ring were found at the nape. Weight: $0.7 \mathrm{~g}$ (Fig. 13.58.1)

\section{Grave 59 (Fig. 13.59)}

Grave-pit: already on the scraped level, very shallow.

Dimensions: Length: $82 \mathrm{~cm}$, Width: $35 \mathrm{~cm}$, Depth: $0 \mathrm{~cm}$

Orientation: W-E

Human remains: very poorly preserved skeleton of a child, perhaps laid on its left side

Orientation of the skeleton: W-E

Anthropological description: 8-9 years old, infans II

Grave inventory:

1. Base fragment of a dark grey, small pot, found at the knee. Its surface is rough. Diameter at the base: $6 \mathrm{~cm}$, Thickness: $0.6 \mathrm{~cm}$ (Fig. 13.59.1)

2. A chipped stone micro blade was found close to the grave pit with one rib at the front side. It has triangular cross-section, its talon is birdwingshaped, with a big bulbus. The distal end is stair-like, the proximal is stumpy. There is small fragmentation on the right blade, while both the left blade on the front, proximal and at the back, distal side have worked with one-raw retouch. The raw material is probably Sümeg radiolarit. Length: $2.954 \mathrm{~cm}$, Width: $1.22 \mathrm{~cm}$, Thickness: $0.549 \mathrm{~cm}$ (Fig. 13.59.2)

\section{Grave 60 (Fig. 13.60)}

Grave-pit: narrow, relatively short, slightly rectangular Dimensions: Length: $143 \mathrm{~cm}$, Width: $67 \mathrm{~cm}$, Depth: $34 \mathrm{~cm}$ Orientation: W-E 


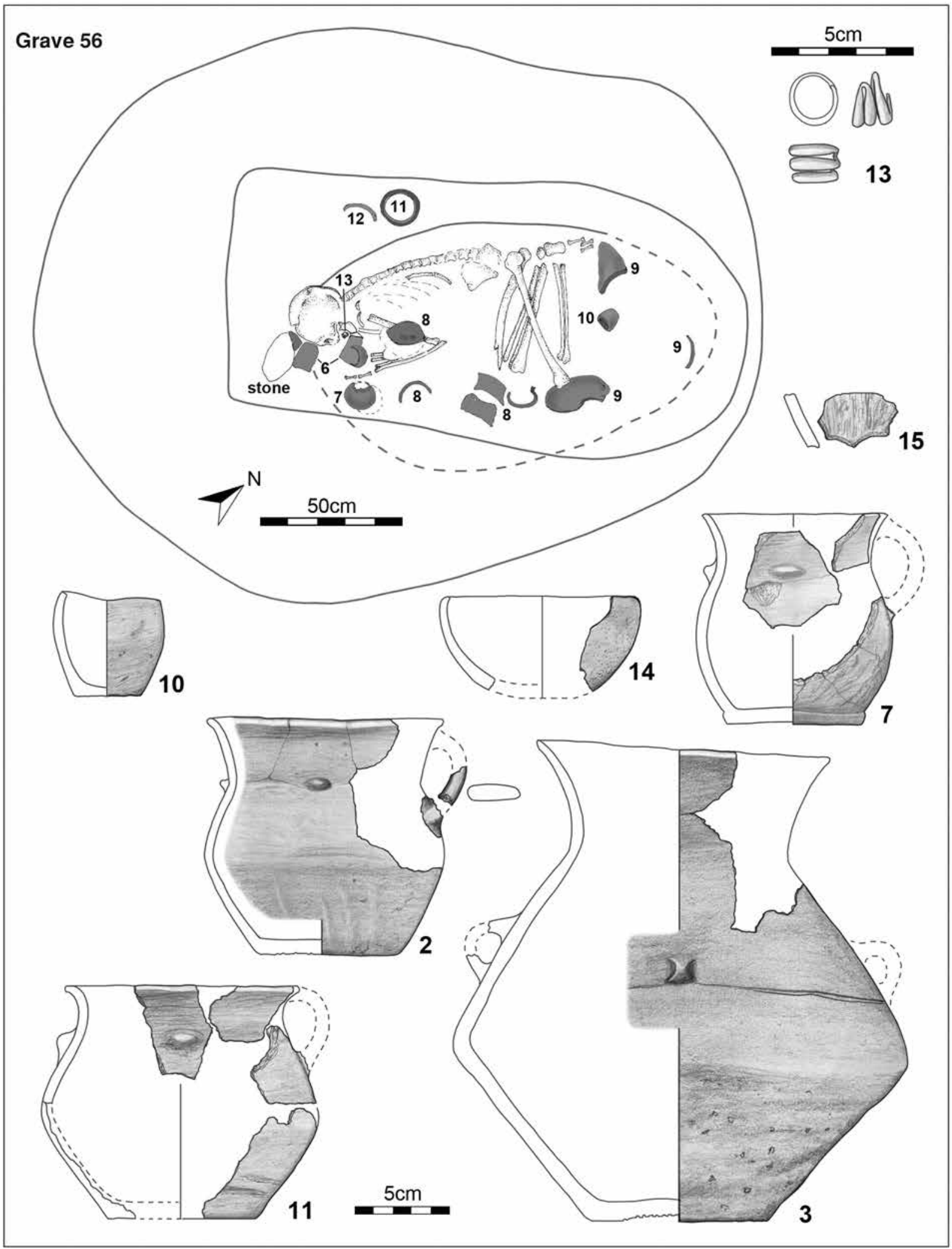

Fig. 11. Nagycenk-Lapos-rét, grave 56 


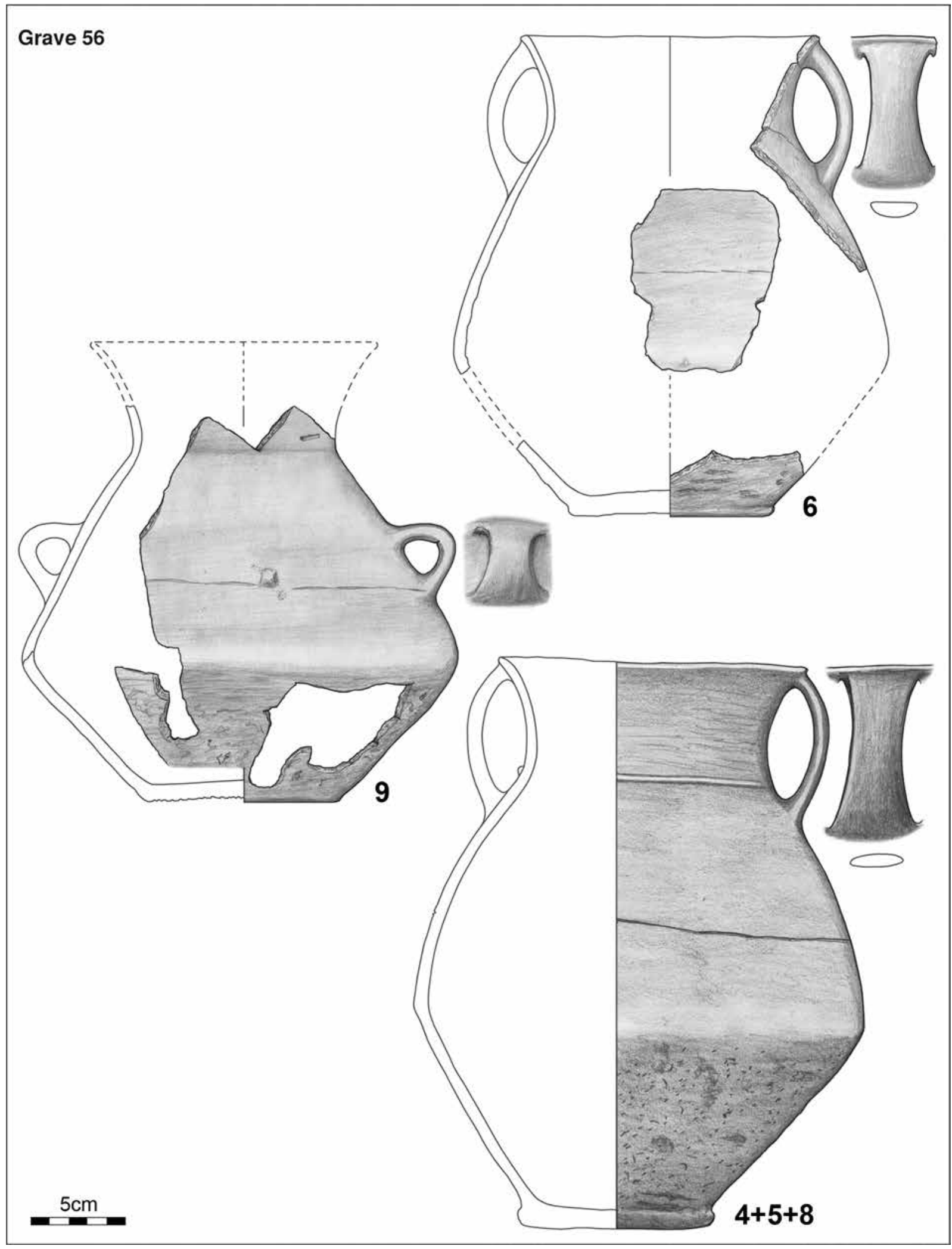

Fig. 12. Nagycenk-Lapos-rét, grave 56 


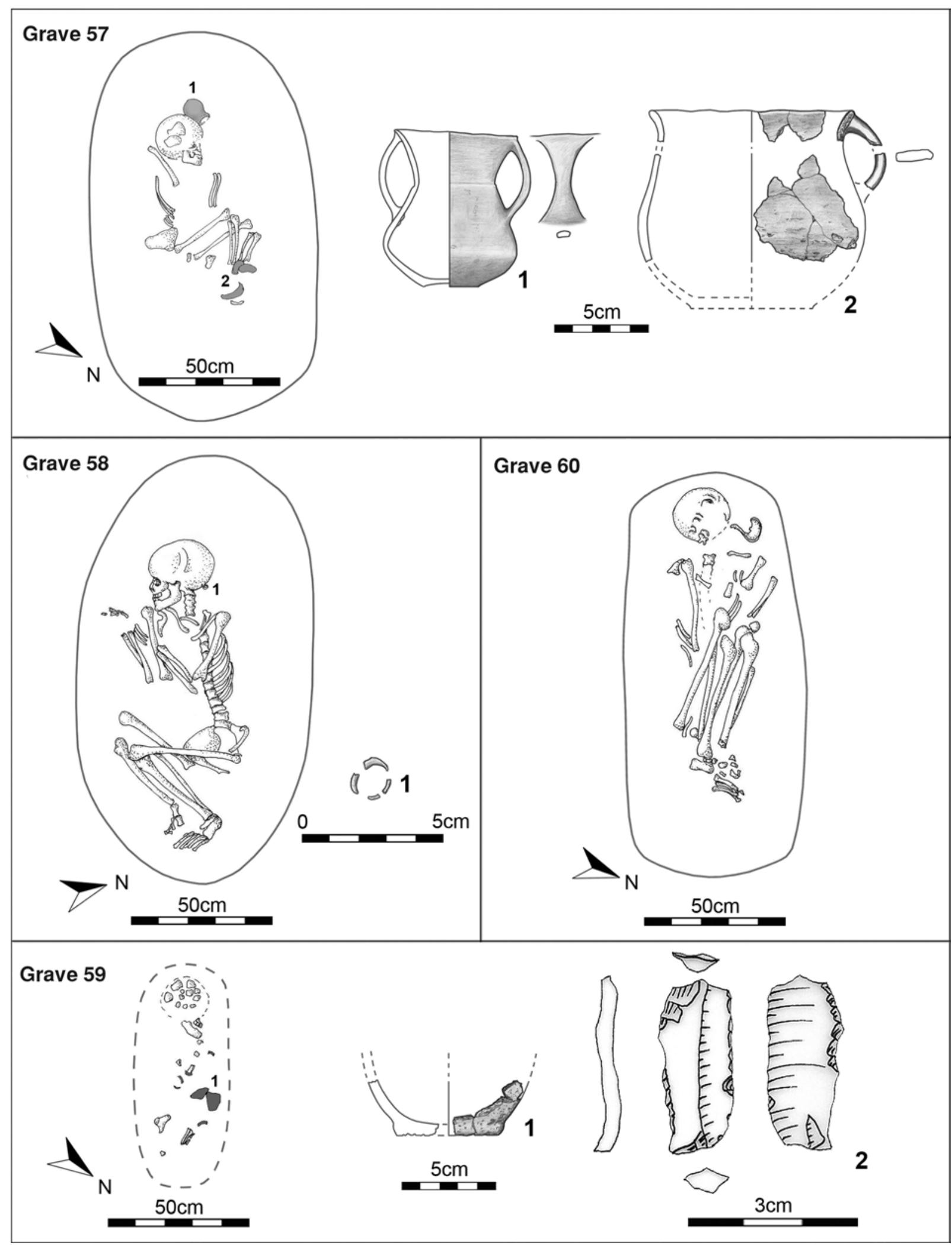

Fig. 13. Nagycenk-Lapos-rét, grave 57, grave 58, grave 59, grave 60 
Human remains: Well preserved skeleton. The skull was detected at a depth of $-25 \mathrm{~cm}$, it was looking left, with the jaw turned out of its place. The skeleton was laid supine, arms were resting on the chest, knees were turned to the left and were tightly crouched, in front of the chest. Orientation of the skeleton: W-E

Anthroplogical description: 40-46 years old, male

Grave inventory: none

\section{Grave 61 (Fig. 14.61)}

Grave-pit: relatively large, with rounded corners.

Dimensions: Length: $205 \mathrm{~cm}$, Width: $133 \mathrm{~cm}$, Depth: $33 \mathrm{~cm}$

Orientation: W-E

Human remains: laid on its left side, well preserved skeleton, the skull was looking north, the arms were flexed in front of the upper part of the body, the hands were placed in front of the face, open palms, one resting upon the other. Legs were pulled up tightly on the left side.

Orientation of the skeleton: W-E

Anthropological description: 48-54 years old, male

Grave inventory:

1. Copper or bronze spiral arm ring, with 11-turns. Ends were narrowed down. Length: $6.4-7.4 \mathrm{~cm}$, Thickness: $0.5 \mathrm{~cm}$, Width: $5.8 \mathrm{~cm}$, Weight: $161 \mathrm{~g}$ (Fig. 14.61.1)

2. While removing the bones, there was a copper or bronze pin with flattened and rolled head (Rollenkopfnadel), found underneath the left shoulder. It has rounded cross section. Length: $12 \mathrm{~cm}$, Thickness: $0.3 \mathrm{~cm}$, Weight: $6.2 \mathrm{~g}$ (Fig. 14.61.2)

3. Flattened spherical shaped amber bead. Original position in the grave is unknown: near the pin. Length: $1.2 \mathrm{~cm}$, Diameter: $1.8 \mathrm{~cm}$, Weight: $1.1 \mathrm{~g}$ (Fig. 14.61.3)

\section{Grave 62 (Fig. 15)}

Grave-pit: compared to the size of the skeleton, it is remarkably large, but also shallow.

Dimensions: Length: $210 \mathrm{~cm}$, Width: $134 \mathrm{~cm}$, Depth: $22 \mathrm{~cm}$

Orientation: W-E

Human remains: moderately well preserved skeleton, prone position, skull tilted to the left, looking NNE, arms were placed along the upper part of the body, legs were moderately flexed on the left side.

Orientation of the skeleton: W-E

Anthropological description: $32-38$ years old, male

Grave inventory:

1. Copper neck ring (Ösenhalsring) with thick flattened and rolled end, and round cross-section, found on the neck. Diameter: $14.6 \mathrm{~cm}$, Thickness: $1 \mathrm{~cm}$, Weight: $148.7 \mathrm{~g}$ (Fig. 15.62.1)

2. Bronze dagger, with five rivet holes and thick middle part, found near the right elbow. Middle part of the blade is widened. Around the hilt plate traces of brown organic material show the remains and a shape of a wooden handle. Only two rivets and the fragments of a third one were found. Length: $11.9 \mathrm{~cm}$, Weight: $41.9 \mathrm{~g}$, Length of rivets: 0.7 and $0.8 \mathrm{~cm}$, Weight of rivets: $0.7 \mathrm{~g}$ (Fig. 15.62.2)

3. Deep bowl with burnished surface, dark-grey colour, found at the left side of the skull. It has strongly everted rim, smoothed shoulder, conical lower part. Much of the upper part was restored. There is no trace of handles on the remaining parts. Diamater at the rim: $25 \mathrm{~cm}$, Height: $10 \mathrm{~cm}$, Diameter at the base: $6 \mathrm{~cm}$, Thickness: $0.4 \mathrm{~cm}$ (Fig. 15.62.3)

4. Double-handled, burnished jug, dark-brown colour, found inside find no. 3. It has funnel neck, biconical body. The two handles are starting from the rim and attached to the upper part of the vessel; this upper part of the body is decorated by two horizontal incisions running around. Diameter at the rim: $10 \mathrm{~cm}$, Height: $12.5 \mathrm{~cm}$, Diameter at the base: $5 \mathrm{~cm}$, Thickness: $0.5 \mathrm{~cm}$, Width of the handles: $1,7 \mathrm{~cm}$ (Fig. 15.62 .4 )

\section{Grave 64 (Fig. 14.64)}

Grave-pit: shallow, and its northeast end is wider (towards the feet).

Dimensions: Length: $120 \mathrm{~cm}$, Width: $76 \mathrm{~cm}$, Depth: $17 \mathrm{~cm}$

Orientation: SW-NE

Human remains: flexed body, laid on its left side. The skull is looking NE, right arm is placed in front of the upper part of the body, legs were moderately flexed, lower limbs tightly pulled up to the thigs.

Orientation of the skeleton: W-E

Anthropological description: 23-39 years old, female 


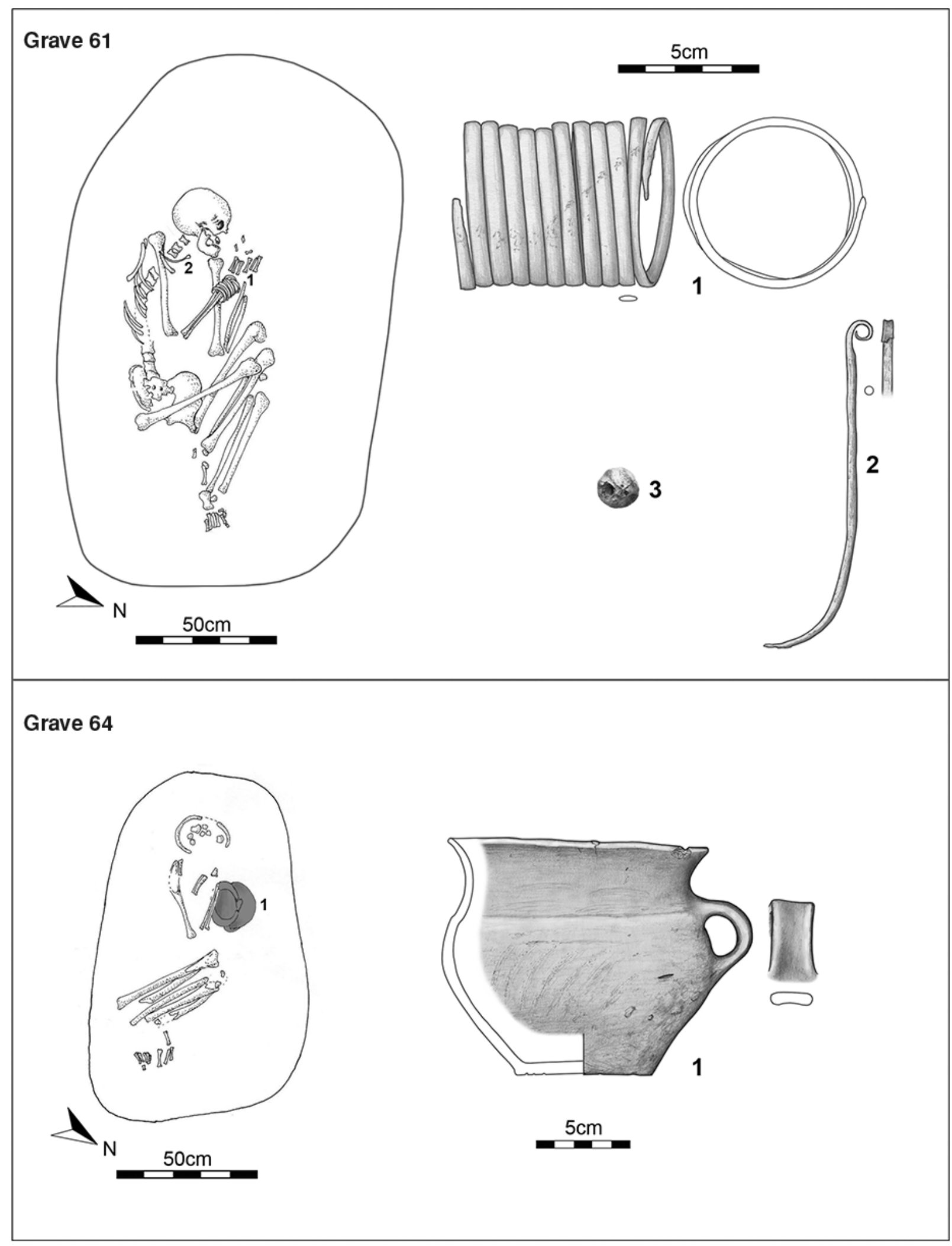

Fig. 14. Nagycenk-Lapos-rét, grave 61, grave 64 
Grave inventory:

1. Small, single handled pot, with burnishing on the neck, found at the right lower arm. It has everted rim, wide mouth, curved neck, smoothed shoulder, conical lower part. The vessel is decorated with finger-grooves. Its short strap handle was attached from the lower part of the neck to the upper part of the body. Signs of wear on the rim. Diameter at the rim: $13.5 \mathrm{~cm}$, Height: $12 \mathrm{~cm}$, Diameter at the base: $7.5 \mathrm{~cm}$, Thickness: $0.5 \mathrm{~cm}$ (Fig. 14.64.1)

\section{Grave 65 (Fig. 16-17.65)}

Grave-pit: oval shaped, shallow pit, with two skeletons, one on top of the other with a few cms difference.

Dimensions: Length: $240 \mathrm{~cm}$, Width: $60-120 \mathrm{~cm}$, Depth: $30 \mathrm{~cm}$

Orientation: W-E

Human remains: Both skeletons are relatively poorly preserved. The skull of the upper one is placed right on top of that of the other. The lower one, to the left, is skeleton ' $A$ '. The upper one, to the right, is skeleton ' $B$ '.

Skeleton 'A' was laid supine, skull was turned left, looking north, the legs were pulled up, and turned to the same side. The right arm was bent at right angles, resting on the upper part of the body.

Skeleton 'B' was laid on its left side, the skull looking northeast, the right arm was bent, and placed on the upper body. Legs were moderately pulled up, and the lower legs were fully flexed to the thighs.

Orientation of the skeletons: W-E

Anthropological description: Skeleton 'A': 23-39 years old, female; skeleton 'B': 23-59 years old, male

Grave inventory:

1. Fragments of a large, brownish grey bowl, found to the immediate south of the skulls. Its base is approximately $10 \mathrm{~cm}$ higher than the skull. It is burnished inside and outside on the neck, while the body is decorated with finger-grooves on the coarse surface. It has everted rim, curved neck. The body has a reversed truncated cone shape. There is also one remaining strap handle, attached to the shoulder, and decorated by a double knob. Diameter at the rim: $50 \mathrm{~cm}$, Height (reconstructed): $23 \mathrm{~cm}$, Thickness: $1 \mathrm{~cm}$ (Fig. 16.65.1)

2. Nondiagnostic fragments of at least three different vessels, found in a pile, to the southwest of the skulls

3. Handled pot, dark grey colour, with light brown stains and burnished surface, found to the right from the skull of skeleton 'A', turned on its side, with the mouth of the pot looking northeast. It has everted rim, curved neck, globular body, with a strap handle, pulled from the rim, and applied to the upper part of the bowl. The base is slightly impressed, shaping a flat omphalos. Diameter at the rim: $16 \mathrm{~cm}, \mathrm{Height:} 14.5 \mathrm{~cm}$, Diameter at the base: $7.6 \mathrm{~cm}$, Thickness: $0.5 \mathrm{~cm}$ (Fig. 16.65.3)

4. Small, asymmetric, deformed pot, found at the right shoulder of Skeleton 'A', standing on its base. It has everted rim, curved profile; light brown colour on the outside, dark grey on the inside, with coarse, uneven surface. Diameter at the rim: $13.5 \mathrm{~cm}$, Height: $12.5 \mathrm{~cm}$, Diameter at the base: $9.5 \mathrm{~cm}$, Thickness: $0.6 \mathrm{~cm}$ (Fig. 16.65.4)

5. Small pot, dark grey colour, with light brown stains, found underneath the left side of Skeleton 'B'. It has everted rim, curved neck, ovoid body. The neck and the shoulder are burnished, the body is covered with a rough clay, smeared layer. There is no trace of a handle. Diameter at the rim: $12.5 \mathrm{~cm}$, Height (max.): $10 \mathrm{~cm}$, Thickness: $0.7 \mathrm{~cm}$ (Fig. 17.65.5)

6. Double-handled cup, found at the knee of Skeleton 'B', with its mouth facing southwest. It has funnel neck, slightly biconical body; light brown on the outside, grey on the inside, with worn burnishing. The hour-glass shaped handles are attached to the rim, and applied to the shoulder. Above the carination on the vessel there is a shallow incision running around. Diameter at the rim: $9 \mathrm{~cm}$, Height: $10 \mathrm{~cm}$, Diameter at the base: $4 \mathrm{~cm}$, Thickness: $0.4 \mathrm{~cm}$, Width of the handle: $1.4-2.4 \mathrm{~cm}$ (Fig. 17.65.6)

Grave 66 (Fig. 17.66-Fig. 18.66)

Grave-pit: large, egg-shaped, and very shallow.

Dimensions: Length: $190 \mathrm{~cm}$, Width: $160 \mathrm{~cm}$, Depth: $13 \mathrm{~cm}$

Orientation: SW-NE

Human remains: Double burial. According to the anthropological analysis the bone fragments of a child and bones of a woman were identified. As the pit was shallow, bones lying higher (e.g. the right leg, or the top of the skull) could be displaced by agricultural work (ploughing). The ceramic vessels were detected already at the level of the scraped surface. The skull of the adult was on its side, facing north, the upper body was laid supine, with the right arm across the chest (probably pulled up to the left shoulder). The legs were moderately pulled up and turned to the left. Orientation of the skeleton: W-E

Anthroplogical description: 23-29 years old, female; 1-6 year-old child (infans I)

Grave inventory: 


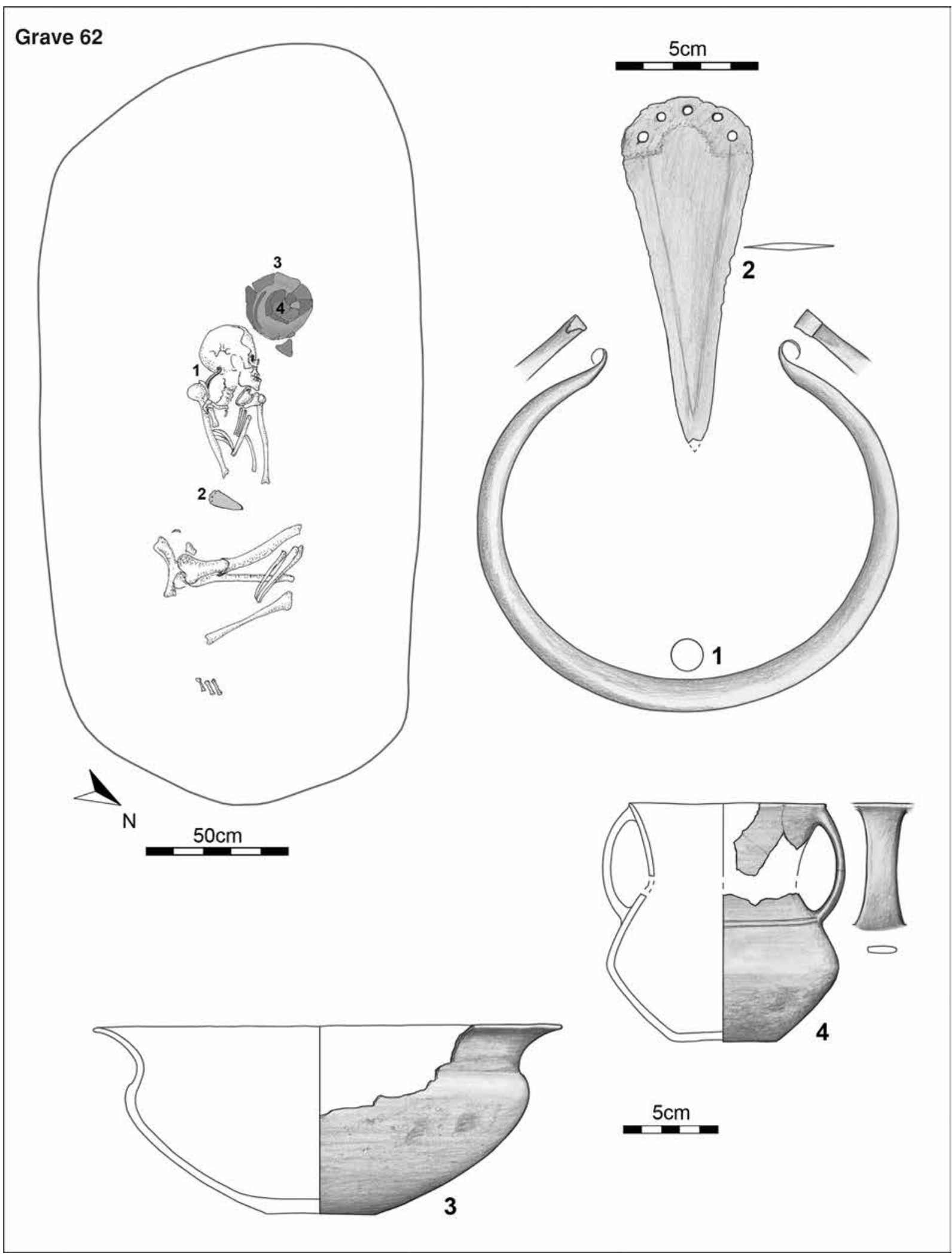

Fig. 15. Nagycenk-Lapos-rét, grave 62

Acta Archaeologica Academiae Scientiarum Hungaricae 69, 2018 


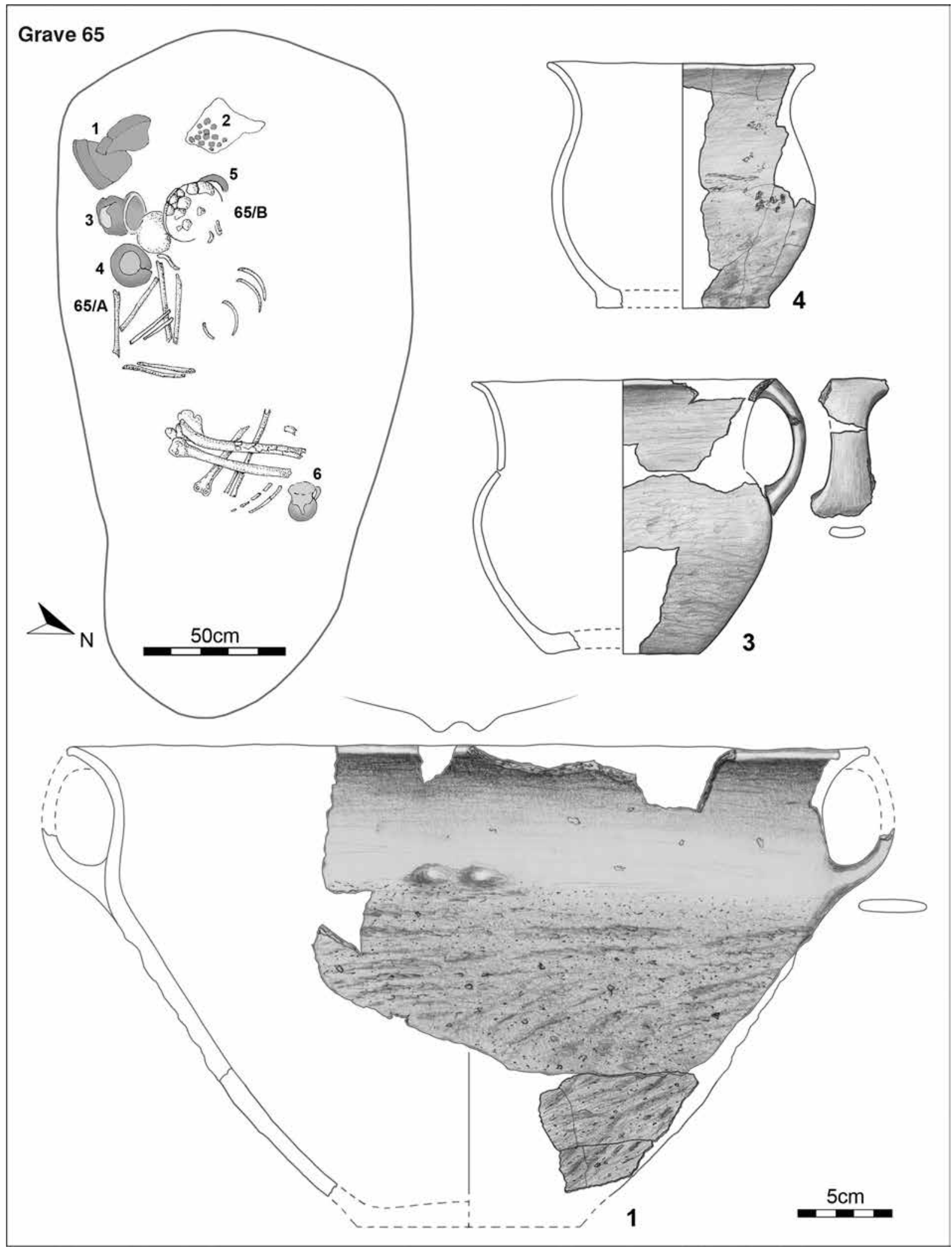

Fig. 16. Nagycenk-Lapos-rét, grave 65 


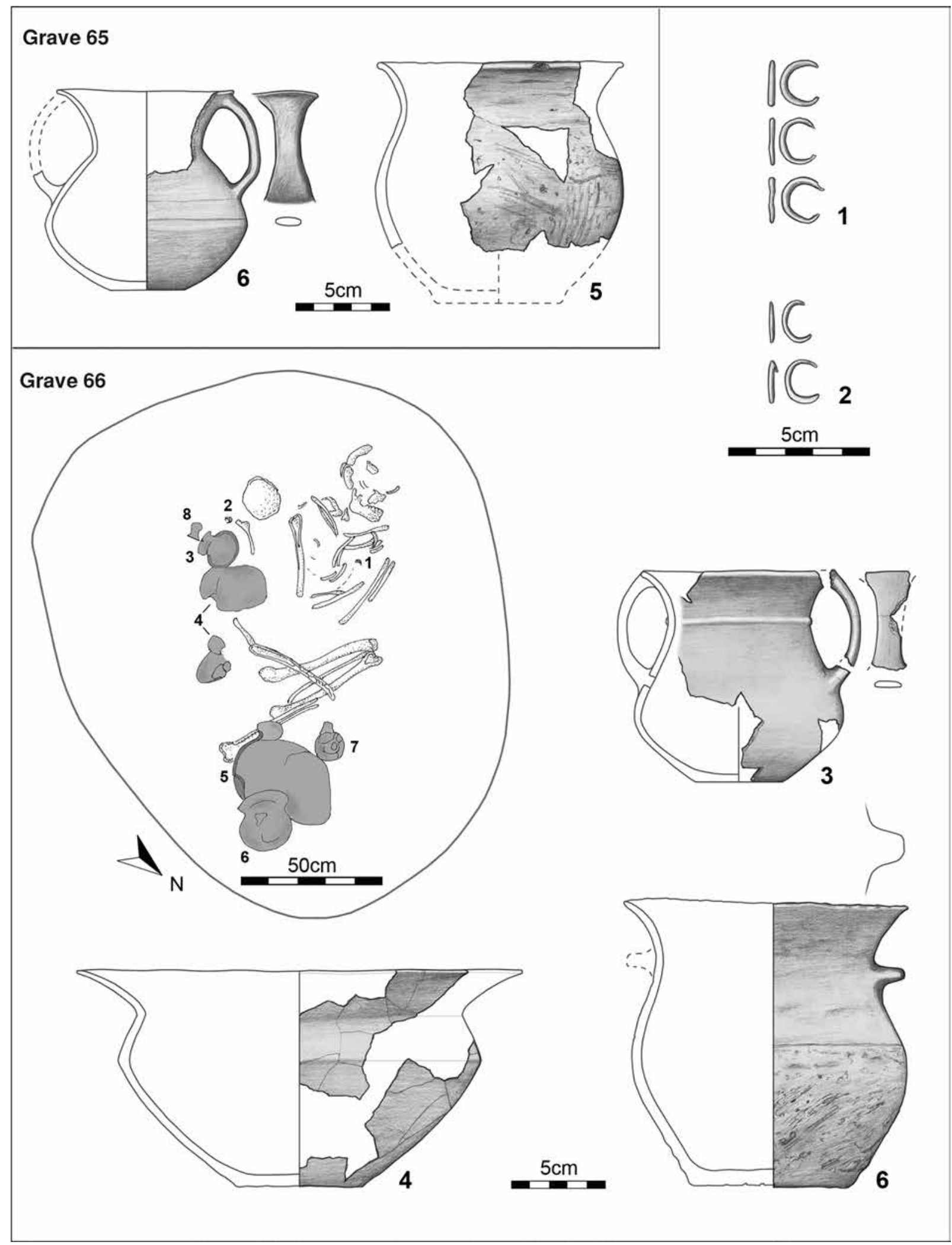

Fig. 17. Nagycenk-Lapos-rét, grave 65, grave 66 
1. Fragments of a copper or bronze hair ring, found near the right hand (in secondary position, as the skull was disturbed). Diameter: $1.7 \mathrm{~cm}$, Thickness: $0.2 \mathrm{~cm}$, Weight: $2.7 \mathrm{~g}$ (Fig. 17.66.1)

2. Fragments of a bronze hair ring. Found beside the displaced skull. Diameter: $1.5 \mathrm{~cm}$, Thickness: $0.2 \mathrm{~cm}$, Weight: $1.2 \mathrm{~g}$ (Fig. 17.66.2)

3. Double-handled cup, grey colour, with light brown stains, found on the right side of the upper body. It is turned on its side, with its mouth looking south. It has everted rim, curved neck, stout, biconical body, and worn burnishing on the surface. There is a shallow rib around the neck; the handle was attached to the rim and applied to the shoulder. Diameter at the rim: $10 \mathrm{~cm}$, Height: $11 \mathrm{~cm}$, Diameter at the base: $5 \mathrm{~cm}$, Thickness: $0.5 \mathrm{~cm}$ (Fig. 17.66.3)

4. Deep bowl with reversed conical shape, and dark grey colour found on the right side of the skeleton, underneath find no. 3. It has strongly everted rim, sharp carination on the body, burnished surface. It was already broken and fragmented into several pieces when placed in the grave. Diameter: $23 \mathrm{~cm}$, Height: $11 \mathrm{~cm}$, Diameter at the base: $6.5 \mathrm{~cm}$, Thickness: $0.4-0.5 \mathrm{~cm}$ (Fig. 17.66.4)

5. Amphora with asymmetric handles, dark grey on the outside, light brown on the inside, found at the right lower leg. It has large, everted rim, funnel neck, slightly biconical body. There is a rib running around the neck. Two long, hour-glass shaped handles, attached to the rim and applied to the shoulder. There is also a small strap handle on the upper part of the vessel. Diameter at the rim: $17 \mathrm{~cm}$, Height (reconstructed): $23 \mathrm{~cm}$, Diameter at the base: $10 \mathrm{~cm}$, Thickness: $0.5 \mathrm{~cm}$ (Fig. 18.66.5)

6. Small pot, dark grey, found beside no. 5, to the east of it, with its mouth facing south. It has curved profile, the upper part is burnished on the outside; there is a slightly oblique oval knob handle on the shoulder, in front of that, the neck and the rim were restored. At the middle of the belly there is a shallow incision running around, below that, the surface is made rough. Diameter at the rim: $14.5 \mathrm{~cm}$, Height: $14 \mathrm{~cm}$, Diameter at the base: $8 \mathrm{~cm}$, Thickness: $0.6 \mathrm{~cm}$ (Fig. 17.66.6)

7. Handled pot, light brown colour, with grey stains, found beside find no. 5, to the northwest of it, standing on its base. It has everted, fragmented, curved rim, slightly everted (funnel) neck, stout globular body, asymmetric. A short, oblique strap handle is attached to the rim, applied to the carination on the belly. Diameter at the rim: $12.1 \mathrm{~cm}$, Height: $13 \mathrm{~cm}$, Diameter at the base: $7 \mathrm{~cm}$, Thickness: $0.5 \mathrm{~cm}$ (Fig. 18.66.7)

8. Fragment of a small bell-shaped jar, with light brown colour, and grey stains, found beside the upper body, on the right side, next to find no. 3. It has everted rim, and worn burnish on the surface, with stump of a strap handle on the upper part of the vessel. Diameter at the rim: $9 \mathrm{~cm}$, Diameter at the base: $5 \mathrm{~cm}$, Height (reconstructed): $9.5 \mathrm{~cm}$, Thickness: $0.5 \mathrm{~cm}$ (Fig. 18.66.8)

\section{Grave 67 (Fig. 18.67)}

Grave-pit: part of the grave pit was outside the trench. Following the expansion of the trench, it turned out to be very shallow.

Dimensions: Length: $120 \mathrm{~cm}$, Width: $60 \mathrm{~cm}$, Depth: $3 \mathrm{~cm}$

Orientation: SW-NE

Human remains: detected directly at the base of the ploughzone, at $-40 \mathrm{~cm}$, measured from the present-day surface level; thus, the skeleton was disturbed by ploughing, primarily in the area around the skull. Flexed position, turned to the right, the skull looking southeast, the jaw was in place. Arms were tightly flexed in front of the upper body, with the hands placed below the chin. Legs were moderately flexed and turned to the right side.

Orientation of the skeleton: SW-NE

Anthropological description: $31-40$ years old, female

Grave inventory: none.

\section{Grave 68 (Fig 19.68)}

Grave-pit: oval shaped pit, cut 10-20 cm deep into the yellow clay subsoil.

Dimensions: Length: $180 \mathrm{~cm}$, Width: $120 \mathrm{~cm}$, Depth: $16 \mathrm{~cm}$

Orientation: WSW-ENE

Human remains: well preserved, the skull was damaged during excavation, it was turned to the right, looking south. The hands were pulled up, below the face. The upper body was laid prone, the legs were bent at right angles, in "kneeling" position.

Orientation of the skeleton: W-E

Anthropological description: $32-38$ years old, female

Grave inventory:

1. Handled pot, dark grey colour with light brown stains, found at the end of the grave-pit. It has curved profile, burnished on the neck. The body is decorated with brushing, and there are three elongated, triangle sectioned knobs on the shoulder, and the stump of a strap handle. Diameter at the rim: $12 \mathrm{~cm}$, Height: $15 \mathrm{~cm}$, Diameter at the base: $10 \mathrm{~cm}$, Thickness: $0.6 \mathrm{~cm}$, Width of the handle: $2.5 \mathrm{~cm}$ (Fig. 19.68.1) 


\section{Grave 66}
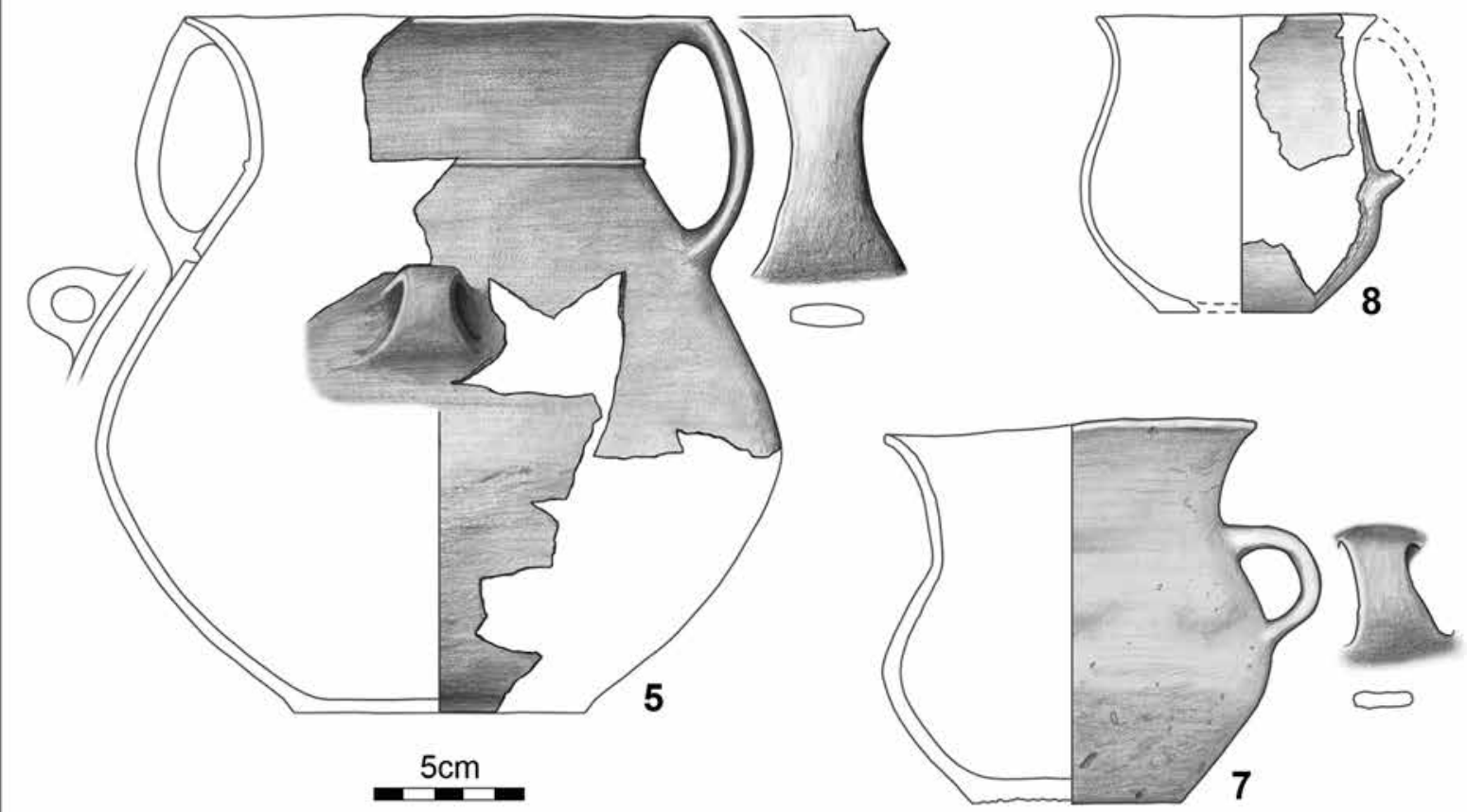

\section{Grave 67}
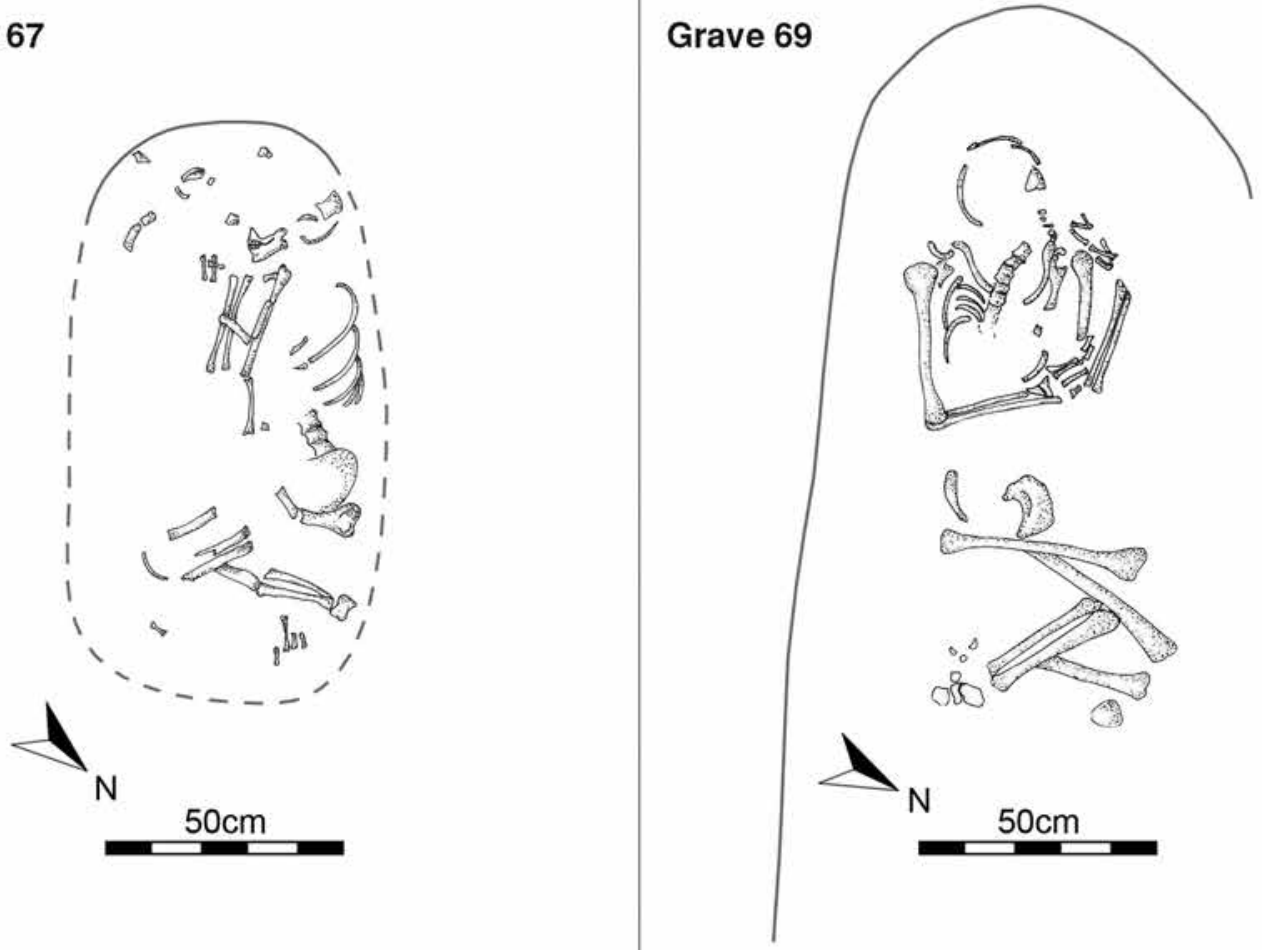

Fig. 18. Nagycenk-Lapos-rét, grave 66, grave 67, grave 69 


\section{Grave 69 (Fig. 18.69)}

Grave-pit: detected directly under the topsoil; $40 \mathrm{~cm}$ below the surface of the ploughzone. Boundaries are uncertain on the east-northeast sides. Dimensions: Length: $200 \mathrm{~cm}$ (partial), Width: $80 \mathrm{~cm}$, Depth: $7 \mathrm{~cm}$

Orientation: W-E

Human remains: the skull was disturbed by the plough. Robust, large skeleton, laid on the back, skull looking north. Below the waist, the body was laid on the left side, legs were moderately pulled up. The right arm was bent at right angles, to the left elbow, across the body. The left hand was pulled up to the left shoulder.

Orientation of the skeleton: W-E

Anthropological description: $36-45$ years old, male

Grave inventory: none.

Grave 70 (Fig 19.70)

Grave-pit: rectangular shape, with rounded corners, shallow.

Dimensions: Length: $160 \mathrm{~cm}$, Width: $80 \mathrm{~cm}$, Depth: $15.5 \mathrm{~cm}$

Orientation: W-E

Human remains: laid on the left side, flexed position, skull turned to the left, looking northeast. Arms were flexed, hands at the chin. Legs were turned on the left side, moderately flexed.

Orientation of the skeleton: W-E

Anthropological description: 14-15 years old, juvenis

Grave inventory:

1. Slightly asymmetric, single-handled cup, dark greyish brown colour, found intact, at the knees, in the northest end of the grave. Its mouth was looking east. It has everted rim, funnel neck, biconical body, burnished surface. A thin rib is running around the neck, from which the short strap handle was pulled, attached above the carination of the belly. Below the handle, there is a double incision running around the body, and opposite to the handle this incision connects to another double incision, which in turn connects to the rib on the neck. Height: $11 \mathrm{~cm}$, Diameter at the rim: $7 \mathrm{~cm}$, Diameter at the base: $3.5 \mathrm{~cm}$, Width of the handle: $1-3 \mathrm{~cm}$, Thickness: $0.3 \mathrm{~cm}$ (Fig 19.70 .1$)$

2. Fragments of a biconical cup, grey colour, with light brown stains, found between the knees and find no. 1. Diameter at the base: $4.5 \mathrm{~cm}$, Height (reconstructed): $5 \mathrm{~cm}$, Thickness: $0.5 \mathrm{~cm}$ (Fig 19.70.2)

3. Wall sherd of another, thicker biconical cup. Height: $3.5 \mathrm{~cm}$, Width: $3 \mathrm{~cm}$, Thickness: $0.9 \mathrm{~cm}$ (Fig 19.70.3)

\section{Grave 71 (Fig. 20.71)}

Grave-pit: not detectable, $170 \mathrm{~cm}$ to the south from grave 70 a skeleton of a child was found at a depth of $13 \mathrm{~cm}$.

Human remains: laid on the right side, skull looking south. Legs were tightly pulled up to the chin. Poorly preserved.

Orientation of the skeleton: W-E

Anthropological description: 5-7 years old, infans I

Grave inventory: none.

\section{Grave 73 (Fig. 20.73)}

Grave-pit: right beside grave 71, a large deposit of daub was detected, as if there was a pit fill, underneath it, there was the grave pit (of rectangular shape, with rounded corners).

Dimensions: Length: $120 \mathrm{~cm}$, Width: $80 \mathrm{~cm}$, Depth: $18 \mathrm{~cm}$

Orientation: E-W

Human remains: well preserved skeleton, with reversed orientation compared to the other burials, with the head to the east, and legs to the west, laid prone. Skull turned to the right, looking north. Arms were crossed under the belly. The skull was buried almost $10 \mathrm{~cm}$ deeper than the pelvis. Legs were turned to the right, flexed, the lower limbs pulled up to the pelvis, almost as if the body was squeezed into the pit. Orientation of the skeleton: E-W

Anthropological description: $28-34$ years old, female

Grave inventory:

1. Smaller amphora with asymmetric handles, dark grey colour. found in front of the face, but not very closely, in the northeast corner of the grave. Its funnel neck, and biconical body is burnished. The vessel is considerably restored. Two hour-glass shaped handles were attached to the neck below the rim. Inbetween the handles there is also a round shaped strap handle, attached to the upper part of the vessel, opposite to which 


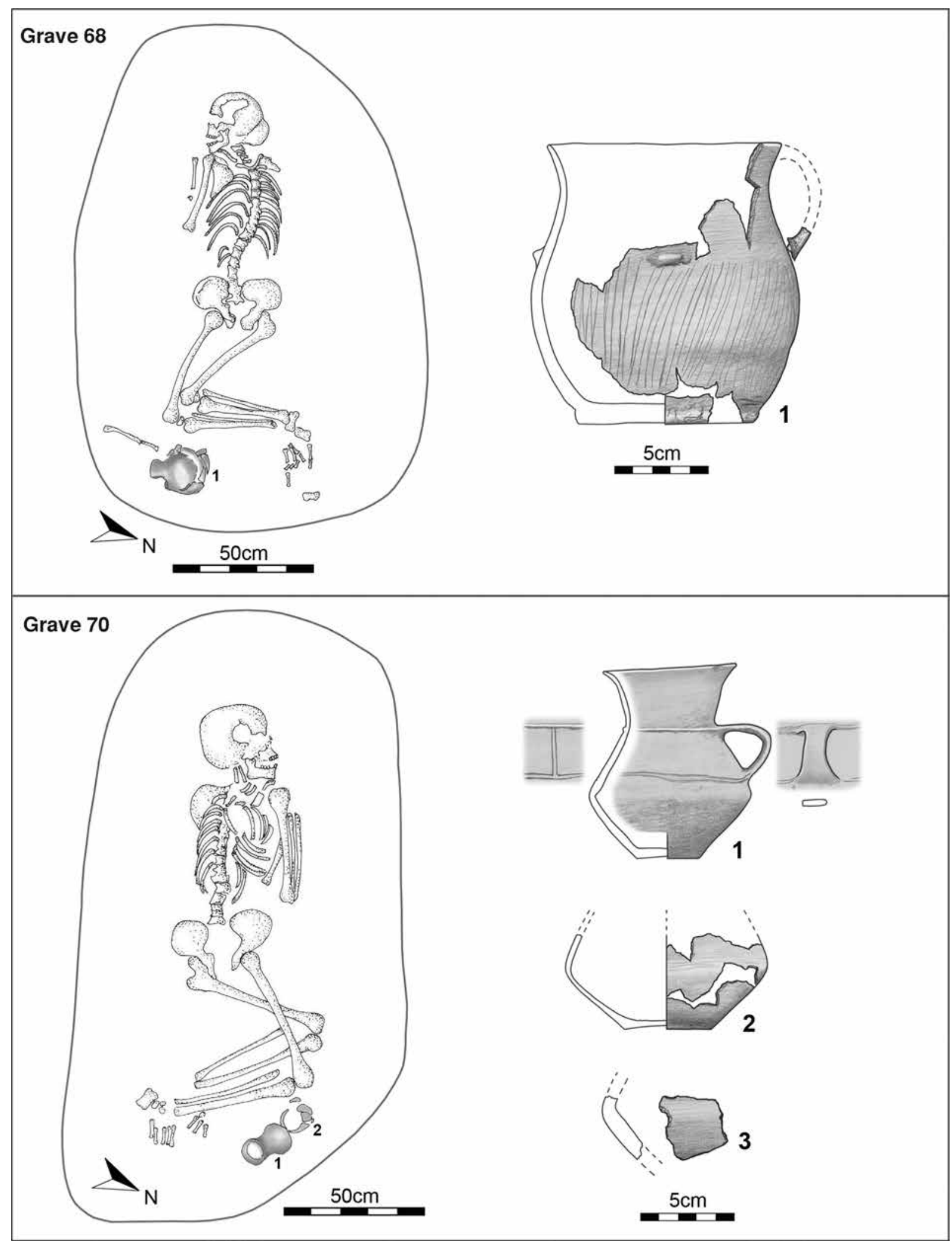

Fig. 19. Nagycenk-Lapos-rét, grave 68 , grave 70 
there is an appliquè swallowtail motive. The shoulder is decorated with a shallow rib. Diameter at the rim: $14.7 \mathrm{~cm}, \mathrm{Height}: 17 \mathrm{~cm}$, Diameter at the base: $8 \mathrm{~cm}$, Thickness: $0.4-0.5 \mathrm{~cm}$ (Fig. 20.73.1)

2. Single handled cup, with yellowish brown colour, and worn burnishing found at the left elbow. The intact vessel has everted rim, the neck and the vessel have a pronouncedly biconical shape. The wide strap handle was attached below the rim and to the shoulder. Diameter at the rim: 8.3 cm, Height: $10.1 \mathrm{~cm}$, Diameter at the base: $3 \mathrm{~cm}$, Thickness: $0.4 \mathrm{~cm}$ (Fig. 20.73.2)

\section{Grave 74 (Fig. 20.74)}

Grave-pit: shallow, its boundaries are a little uncertain

Dimensions: Length: $160 \mathrm{~cm}$, Width: $90 \mathrm{~cm}$, Depth: $10 \mathrm{~cm}$

Orientation: W-E

Human remains: poorly preserved, laid on its rights side, flexed, looking southeast. Arms were flexed in front of the upper body, legs were tightly pulled up to the rights side, the elbows and knees almost touch.

Orientation of the skeleton: W-E

Anthropological description: 23-39 years old, female

Grave inventory:

1. Fragments of a double-handled amphora, dark grey colour, with reddish hue where the burnishing is worn off, found at the feet, in the northeast end of the grave-pit. It has everted rim, funnel neck. Diameter at the rim: $15 \mathrm{~cm}$, Height (reconstructed): $8 \mathrm{~cm}$, Width of the handle: $3 \mathrm{~cm}$, Thickness: $0.6 \mathrm{~cm}$ (Fig. 20.74.1)

2. Bell shaped, single-handled cup, reddish brown on the outside, dark grey on the inside, found north of find no.1, with its mouth tilted towards east. It has everted rim, curved neck. There are three incised lines running around the body at the height of the bottom of the handle. Height: $10 \mathrm{~cm}$, Diameter at the base: $4 \mathrm{~cm}$, Diameter at the rim: $9 \mathrm{~cm}$, Thickness: $0.4 \mathrm{~cm}$ (Fig. 20.74.2)

3. Fragments of a large, and thick-walled vessel, brownish grey, found at the southeast side of the grave-pit. Height: $3.2 \mathrm{~cm}$, Width: $6.9 \mathrm{~cm}$, Thickness: $1.6 \mathrm{~cm}$

4-5. Fragments of a small, funnel-necked cups, found among the fragments of find no.1. Diameter at the rim: $10 \mathrm{~cm}$, Height: $3 \mathrm{~cm}$, Thickness: $0.3 \mathrm{~cm}$ (Fig. 20.74.4-5)

Grave 75 (Fig. 21, Fig. 22.75)

Grave-pit: in the west part it was partly destroyed by the pit cut of feature no. 50, an Árpád period house.

Dimensions: Length: $50 \mathrm{~cm}$ (partial), Width: $30 \mathrm{~cm}$ (partial), Depth: $30 \mathrm{~cm}$

Orientation: W-E/ E-W

Human remains: only small remains of the non diagnostic human bones were identified

Grave inventory:

1. Handled-pot with a slightly profiled base, dark grey colour, found in the north part of the pit. It has everted rim, and ovoid body, with a strap handle attached from the neck to the shoulder. At the height of its lower part there are also three horizontal knobs on the shoulder. The body is covered with a rough clay layer with finger grooves. Diameter at the rim: $14.5 \mathrm{~cm}, \mathrm{M} .15 \mathrm{~cm}$, Diameter at the base: $6 \mathrm{~cm}$, Thickness: $0.6-0.7 \mathrm{~cm}$, Handle width: $2 \mathrm{~cm}$ (Fig. 22.75.1)

2. Fragments of an amphora with asymmetric handles, found NW from the vessel No. 1. It has funnel-shaped neck, biconical body, and three handles on the belly (Fig. 21)

\section{Grave 76 (Fig. 22.76)}

Grave-pit: ovoid shape, very shallow.

Dimensions: Length: $92 \mathrm{~cm}$, Width: $80 \mathrm{~cm}$, Depth: $6 \mathrm{~cm}$

Orientation: W-E

Human remains: the skeleton was found at a depth of 5-10 cm measured from the scraped surface, bones were poorly preserved, the skull was turned to its right side, facing south, the body was in crouched position.

Anthropological description: 23-39 years old, female

Orientation of the skeleton: SW-NE

Grave inventory:

1. Fragments of a light brown pot with dark grey stains, with knobs, found at the lower leg, tilted to its side, its mouth facing east. It has everted rim, curved wall, one knob on the shoulder, and worn burnishing. Diameter at the rim: $14.5 \mathrm{~cm}$, Height (reconstructed): $14 \mathrm{~cm}$, Thickness: 0.6 cm (Fig. 22.76.1) 


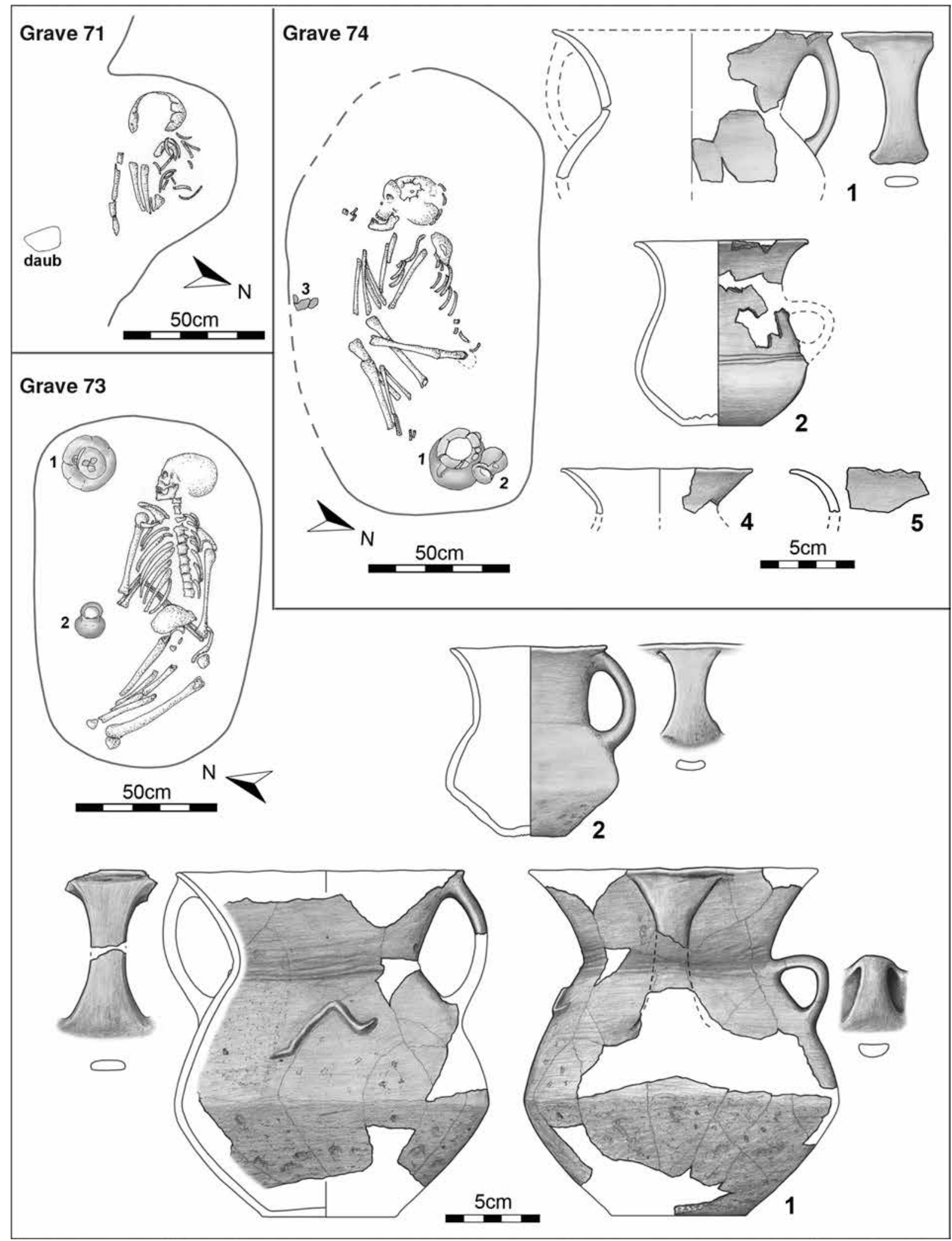

Fig. 20. Nagycenk-Lapos-rét, grave 71, grave 73, grave 74 


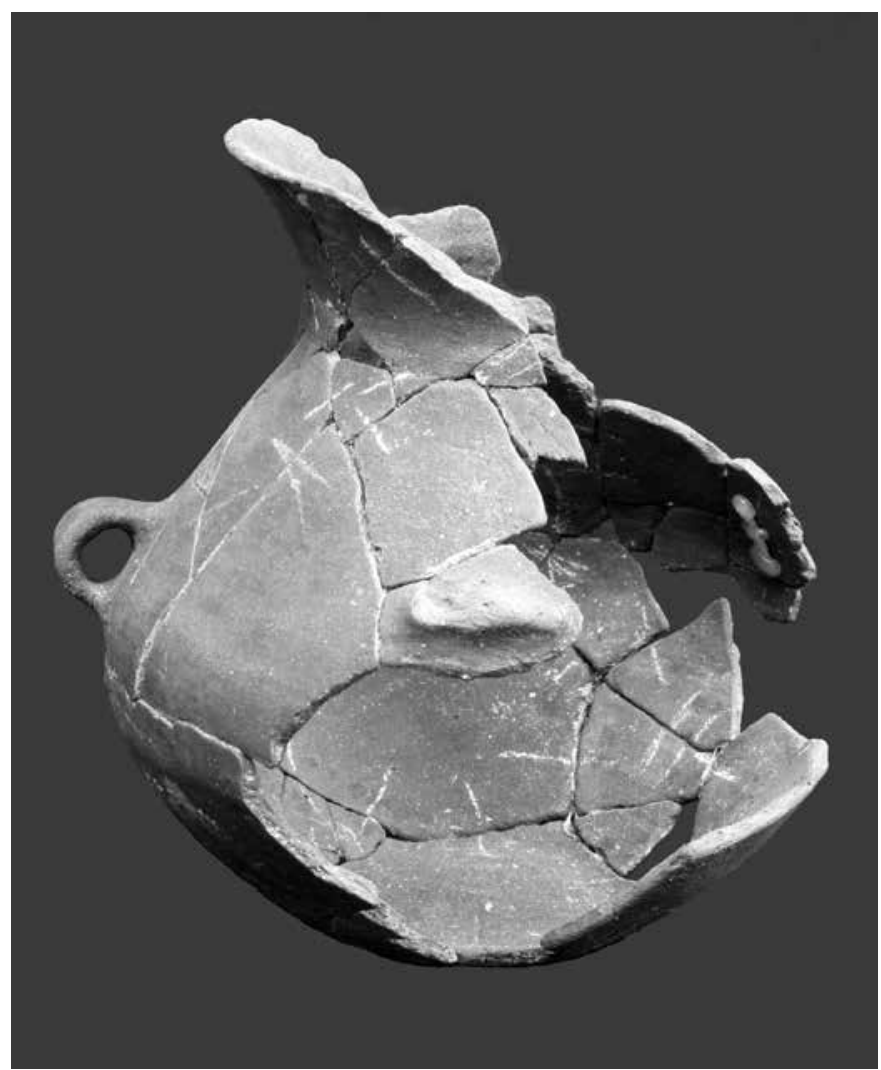

Fig. 21. Nagycenk-Lapos-rét, photo of grave 75, find no. 2 during restoration

2. Bronze hair ring with thick solid bent ends. Found beside find no. 1, at the knee. Diameter: $1.2 \mathrm{~cm}$, Thickness: $0.1 \mathrm{~cm}$, at the widened part: $0.3 \mathrm{~cm}$, Weight: $2.2 \mathrm{~g}$ (Fig. 22.76.2)

3. Bronze hair ring, with solid, tripartite bent ends, found underneath the skull. Similar to find no. 2 . Diameter: $1.2 \mathrm{~cm}$, Thickness: $0.1 \mathrm{~cm}$, at the widened part: $0.3 \mathrm{~cm}$, Weight: $2.8 \mathrm{~g}$ (Fig. 22.76.3)

4. Tubular copper or bronze fragment, found by the conservator when cleaning the skull. Diameter: $0,4 \mathrm{~cm}$, Thickness: $0.15 \mathrm{~cm}$, Weight: $0.3 \mathrm{~g}$ (Fig. 22.76.4)

5. Copper or bronze hair ring, found by the conservator when cleaning the skull. Similar to find no. 2. Diameter: $1.2 \mathrm{~cm}$, Thickness: $0.1 \mathrm{~cm}$, at the widened part: $0.3 \mathrm{~cm}$, Weight: $2.6 \mathrm{~g}$ (Fig. 22.76.5)

\section{Grave 77 (Fig. 23.77)}

Grave-pit: very large, compared to the size of the skeleton, and its shape slightly resembles to that of a kidney.

Dimensions: Length: $230 \mathrm{~cm}$, Width: $110 \mathrm{~cm}$, Depth: $35 \mathrm{~cm}$

Orientation: W-E

Human remains: found at a depth of $30 \mathrm{~cm}$, measured from the scraped surface ( $80 \mathrm{~cm}$ when measured from the topsoil). Skull slightly tilted to the right, facing southeast and slightly gazing up. The upper body was laid supine, the arms were flexed, pulled up to the right, as if holding something. Legs were moderately pulled up to the right.

Orientation of the skeleton: W-E

Anthropological description: 17-21 years old, female

Grave inventory:

1. Bronze head band (diadem) with folded spiral terminals, found on the skull, ca. $1 \mathrm{~cm}$ wide. The edges on the two sides were decorated with punched dots in a row, and in two places the rows form "X"-motives. Diameter: $17 \mathrm{~cm}$, Width: $1.2 \mathrm{~cm}$, Weight: cca. $10 \mathrm{~g}(18.3 \mathrm{~g}$ together with plexi glas!) (Fig. 23.77.1) 


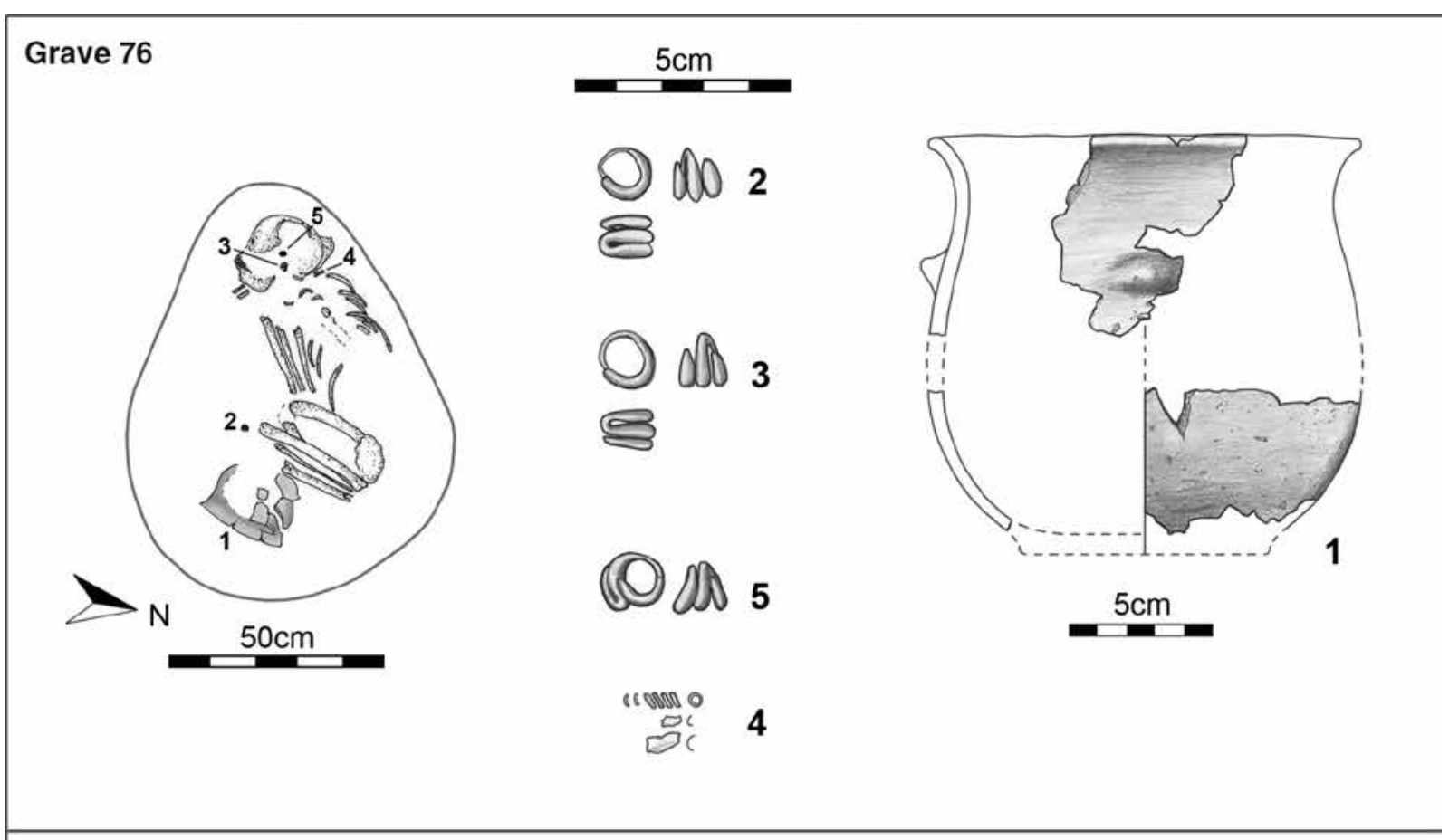

\section{Grave 75}
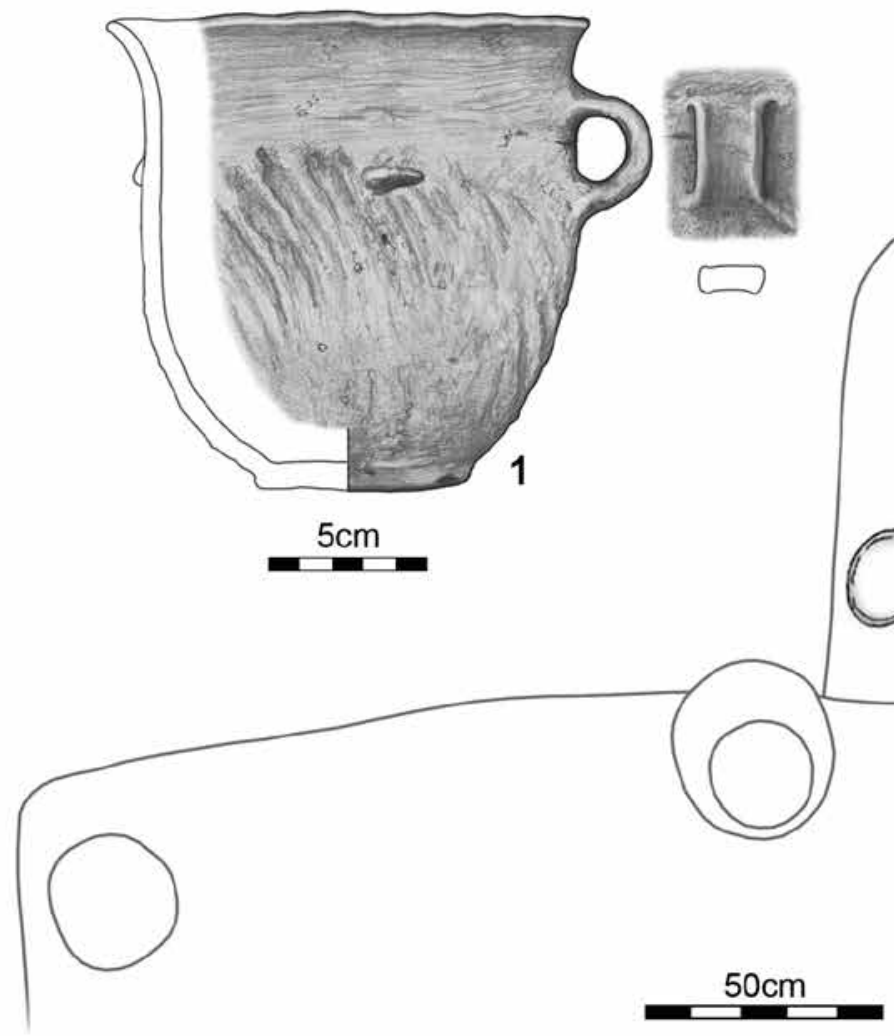

Fig. 22. Nagycenk-Lapos-rét, grave 75 , grave 76 


\section{Grave 78 (Fig. 23.78)}

Grave-pit: very shallow; boundaries were unclear.

Dimensions: H: $110 \mathrm{~cm}$, Width: $55 \mathrm{~cm}$, Depth: $7 \mathrm{~cm}$

Orientation: W-E

Human remains: found directly underneath the scraped surface; possibly disturbed by the plough, only the skull remained, the other bones were decayed.

Orientation of the skeleton: n.a.

Anthropological description: 15-16 years old, infans II

Grave inventory:

1. Small, copper or bronze spiral arm ring, in a 4-turn spiral. Oval sectioned. Found in the central part of the grave. Length: $1.5 \mathrm{~cm}$, Width:

$3.4 \mathrm{~cm}$, Weight: $12 \mathrm{~g}$ (Fig. 23.78.1)

In the eastern part of the grave, there were ceramic vessels disturbed by the plough. They could be collected as separate piles of sherds.

2/A. Fragments of a single-handled deep bowl, dark grey, worn burnishing. Most of the fragments could be assembled. It has everted rim, curved neck, truncated cone shape. Based on the plan of the grave, these could be pile no. 2, consisting of larger fragments, as indicated on the drawing. Diameter at the rim: $19 \mathrm{~cm}$, Diameter at the base: $7 \mathrm{~cm}$, Height (reconstructed): $10 \mathrm{~cm}$, Thickness: $0.7 \mathrm{~cm}$ (Fig. 23.78.2/A)

2/B. Fragments of a single-handled cup, light brown colour, with dark grey stains. Most of them could be assembled. Funnel neck, biconical body. The handle is applied to the upper part of the vessel, it was likely pulled from the shoulder. Below the handle, in the middle of the part there is an incised line running around. The base is slightly impressed, shaping a flat omphalos. Diameter at the base: $3 \mathrm{~cm}$, Height (reconstructed): $8.8 \mathrm{~cm}$, Thickness: $0.6 \mathrm{~cm}$ (Fig. 23.78.2/B)

2/C. Piece of a handle, light brown, with dark grey stains, attached to the vessel by a draught. The surface is smooth. Height: $3.8 \mathrm{~cm}$, Width: $2 \mathrm{~cm}$, Thickness: $0.6 \mathrm{~cm}$ (Fig. 23.78.2/C)

3. Following the restoration these fragments turned to be parts of vessels no. $2 / \mathrm{A}$ and $2 / \mathrm{B}$.

4. Fragments of several vessels. The number 4/B belonged to a biconical, brownish grey cup. The base was cut off. Diameter at the base: $3.5 \mathrm{~cm}$, Height: $3 \mathrm{~cm}$, Thickness: $0.6 \mathrm{~cm}$ (Fig. 23.78.4)

5. Three additional nondiagnostic sherds of thick walled vessels were collected from the fill.

\section{Grave 79 (Fig. 24)}

Grave-pit: very shallow, south boundaries were uncertain.

Dimensions: Length: $170 \mathrm{~cm}$, Width: $80 \mathrm{~cm}$, Depth: $12 \mathrm{~cm}$

Orientation: W-E

Human remains: disturbed by ploughing, the skull is in situ, turned to the right, looking southeast, the other bones were displaced.

Orientation of the skeleton: n.a.

Anthropological description: 23-39 years old, sex undetermined

Grave inventory:

1. Copper neck ring with rolled ends (Ösenhalsring), decorated with wires wrapped around the ends. Most probably from the area of the neck, but it was dragged by the plough towards the chest. Diameter: $16.7 \mathrm{~cm}$, Thickness: $1.3 \mathrm{~cm}$, Weight: $357.8 \mathrm{~g}$ (together with the $0.6 \mathrm{~g}$ spiral fragments) (Fig. 24.79.1)

The burial vessels were also disturbed by the plough. Fragments of altogether six different vessels were identified:

2. Fragments of a large, double-handled amphora, dark grey colour, with light brown stains, found in the southeast part of the grave-pit. It has everted rim, curved neck, burnished surface. Two hour-glass shaped handles were attached to the rim and to the upper part of the vessel. In between them there is a U-shaped rib decorating the upper part of the vessel. Diameter at the rim: $19.5 \mathrm{~cm}$, Height (max.): $13 \mathrm{~cm}$, Thickness: $0.6 \mathrm{~cm}$, Width of the handle: $2.5-4.8 \mathrm{~cm}$ (Fig. 24.79.2)

3. Fragments of a jug, brownish grey. Found at the western edge of the pit. Strongly everted rim, stout, biconical body with burnished surface, the base is slightly impressed, shaping a flat omphalos. The horizontal ribs around the neck, and the upper part of the vessel are connected by a vertical rib. There is also a fragment of a matching handle, which was attached to the upper part of the jug. Diameter at the rim $15.6 \mathrm{~cm}$, Height (max.): $14.5 \mathrm{~cm}$, Diameter at the base: $7 \mathrm{~cm}$, Thickness: $0.5 \mathrm{~cm}$, Width of the handle: $3.2 \mathrm{~cm}$ (Fig. 24.79.3)

4/A. Fragment of a pot, dark grey with light brown stains, found in the northeast part of the grave. It has everted rim, curved neck, ovoid body, burnished surface. Triangular sectioned knob, standing upright on the shoulder. Diameter at the rim: $16 \mathrm{~cm}$, Height: $16 \mathrm{~cm}$, Diameter at the base: $8.5 \mathrm{~cm}$, Thickness: $0.8 \mathrm{~cm}$ (Fig. 24.79.4/A)

4/B. Fragments of a single-handled cup, dark grey with reddish brown stains, found in the northeast part of the pit. Funnel neck, stout, globular body. There is a strap handle applied to the shoulder. Above the carination of the vessel, at the height of the stump of the handle there are three 


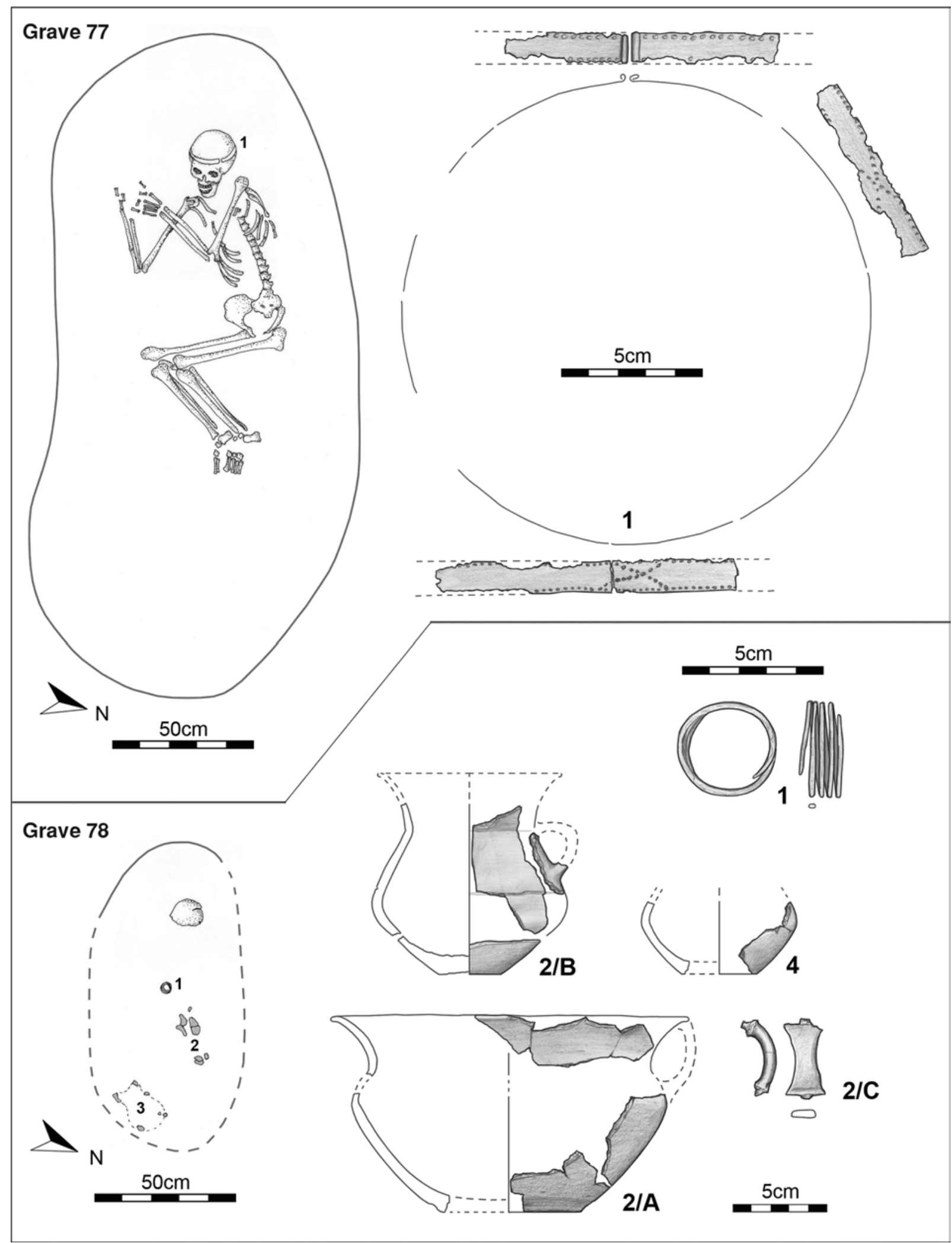

Fig. 23. Nagycenk-Lapos-rét, grave 77, grave 78 
parallel incised lines, running around, and crossed by bands of five lines running down on the upper part of the vessel. Diameter at the base: $5 \mathrm{~cm}$, Height (reconstructed): $11.2 \mathrm{~cm}$, Thickness: $0.4 \mathrm{~cm}$, Width of the handle: $1.5-3.5 \mathrm{~cm}$ (Fig. 24.79.4/B)

5. Fragment of a thick strap handle, dark grey, smooth surface. Height: $3.9 \mathrm{~cm}$, Width: $3.2 \mathrm{~cm}$, Thickness: $1.1 \mathrm{~cm}($ Fig. 24.79 .5$)$

6. Rim fragment possibly from a small pot, straight, light brown colour. Diameter at the rim: $10 \mathrm{~cm}$, Height: $3 \mathrm{~cm}$, Thickness: $0.6 \mathrm{~cm}$ (Fig. 24.79 .6$)$

Feature 22 (Fig. 25-26)

Description: While scraping the surface, this one seemed as if this was an oval shaped grave covered by stones. The whole pit was filled with round river stones, as if the brown humus was only washed into the pit from outside. At $-70 \mathrm{~cm}$ depth (measured from the scraped surface), there were small rim fragments of a bowl found at the eastern side of the pit. Going deeper to $-100 \mathrm{~cm}$ depth, the pit became cylindrical (120 $\mathrm{cm}$ in diameter). At $-200 \mathrm{~cm}$ depth the cut seemed already as a well pit. The well-pit had a regular cylindrical form, cut into the sandy soil. The bottom was reached at $-290 \mathrm{~cm}$.

Orientation: W-E

Description of the finds:

1. Rim fragment of an interior decorated footed bowl. There are circular holes on the rim. On the outside, it is decorated by a band of incised lines below the rim. On the inside, there is a band of notches and below that two incised lines running around. Height: $2 \mathrm{~cm}$, Width: $2.6 \mathrm{~cm}$, Thickness: $1 \mathrm{~cm}$ (Fig. 26.22.1)

2. Wall sherds of a dark grey, handled cup with biconical body, burnished surface, the upper part of the body is decorated with a band of incised lines. Height: $4 \mathrm{~cm}$, Width: $3 \mathrm{~cm}$, Thickness: $0.4 \mathrm{~cm}$ (Fig. 26.22.2)

Feature 27 (Fig. 27-29)

Description: Oval pit, filled with mixed brown soil. The base of the pit was sloping towards the middle, where there were seven Bronze Age vessels, all of them laid on their sides, with their mouths looking southwest. At the north end of the pit, there were three vessels, placed tightly next to one another. This whole set consisted of different storage and cooking vessels, except for bowls and jugs, which were lacking. There were three larger vessels (2/A, 3/A, 4/A), each had smaller vessels inside of them, as discovered during the conservation. The fragments no. 5 and no. 7 turned out to be parts of the same pot during the restoration. Small bone fragments (sheep/goat ${ }^{19}$ ) were found in no. $4 / \mathrm{A}$ vessel.

Dimensions: Length: 190; Width: $100 \mathrm{~cm}$, Depth: $40 \mathrm{~cm}$

Orientation: SW-NE

Description of the finds:

1. Double-handled amphora, dark grey and burnished, found in the west part of the pit. It has strongly everted rim, funnel neck, stout, globular body, with its center of gravity in the lower third. Two short triangularish strap handle on the widest part of the belly. There is an incisied line running around, below the neck and the handles. Diameter at the rim: $16 \mathrm{~cm}$, Height: 20 , Diameter at the base: $8 \mathrm{~cm}$, Thickness: $0.7-0.8 \mathrm{~cm}$ (Fig. 27.27.1)

2/A. Large jug, dark grey, with reddish stains. Found at the northeast end of the pit, between no. 1, and no. 3 . It has strongly everted rim, curved funnel neck, globular body, the base is missing. There is a rib at the bottom of the neck, and there is a short handle attached to here, and to the upper part of the body. Below the handle there is a horizontal rib running around the belly, connected by two vertical ribs, which are positioned at qual distances from the handle. Part of the side opposite the handle is missing. Diameter at the rim: $18 \mathrm{~cm}$, Height (reconstructed): $18 \mathrm{~cm}$, Thickness: $0.5 \mathrm{~cm}$ (Fig. 28.27.2/A)

2/B. Handled pot, light brown colour, with grey strongly everted rim, curved funnel neck, ovoid body, found inside no. 2/A. Strap handle, starting from the rim, and attached to the shoulder. Opposite to the handle there is a fracture surface left by an oval knob. Diameter at the rim: $12 \mathrm{~cm}$, Height: $11 \mathrm{~cm}$, Diameter at the base: $7 \mathrm{~cm}$, Thickness: $0.4 \mathrm{~cm}$ (Fig. 28.27.2/B)

3/A. Amphora with asymmetric handle, grey colour with light brown stain, found in the north part of the pit. It was placed on top of no. 2, but was partly disturbed. It has everted rim, funnel neck, strongly biconical body part, worn burnishing. Two long, hour-glass shaped handles starting below the rim, attached to the shoulder. The bottom of the neck is smoothed, and there is an appliqué swallowtail motive between the two handles, on the upper part of the belly, opposite to which the surface is fractured - there was probably a small handle here. There is an unevenly incisied double line running around on the upper part of the belly. Diameter at the rim: $21 \mathrm{~cm}$, Diameter at the base: $11 \mathrm{~cm}$, Height (reconstucted): $27.5 \mathrm{~cm}$, Thickness: $0.7-0.8 \mathrm{~cm}$ (Fig. 28.27.3/A)

3/B. Single handled small cup, dark grey, found inside no. 3/A during conservation. It has everted rim, funnel neck, slightly asymmetric, biconical body, small base ring. Short strap handle attached to the bottom of the neck, and to the upper part of the belly. Below the handle there is an incised line running around. Diameter at the rim: $9 \mathrm{~cm}$, Height: $11 \mathrm{~cm}$, Diameter at the base: $4.5 \mathrm{~cm}$, Thickness: $0.6-0.4 \mathrm{~cm}$ (Fig. $28.27 .3 / B$ ) animal bones.

${ }^{19}$ We are grateful to Erika Gál for the identification of 


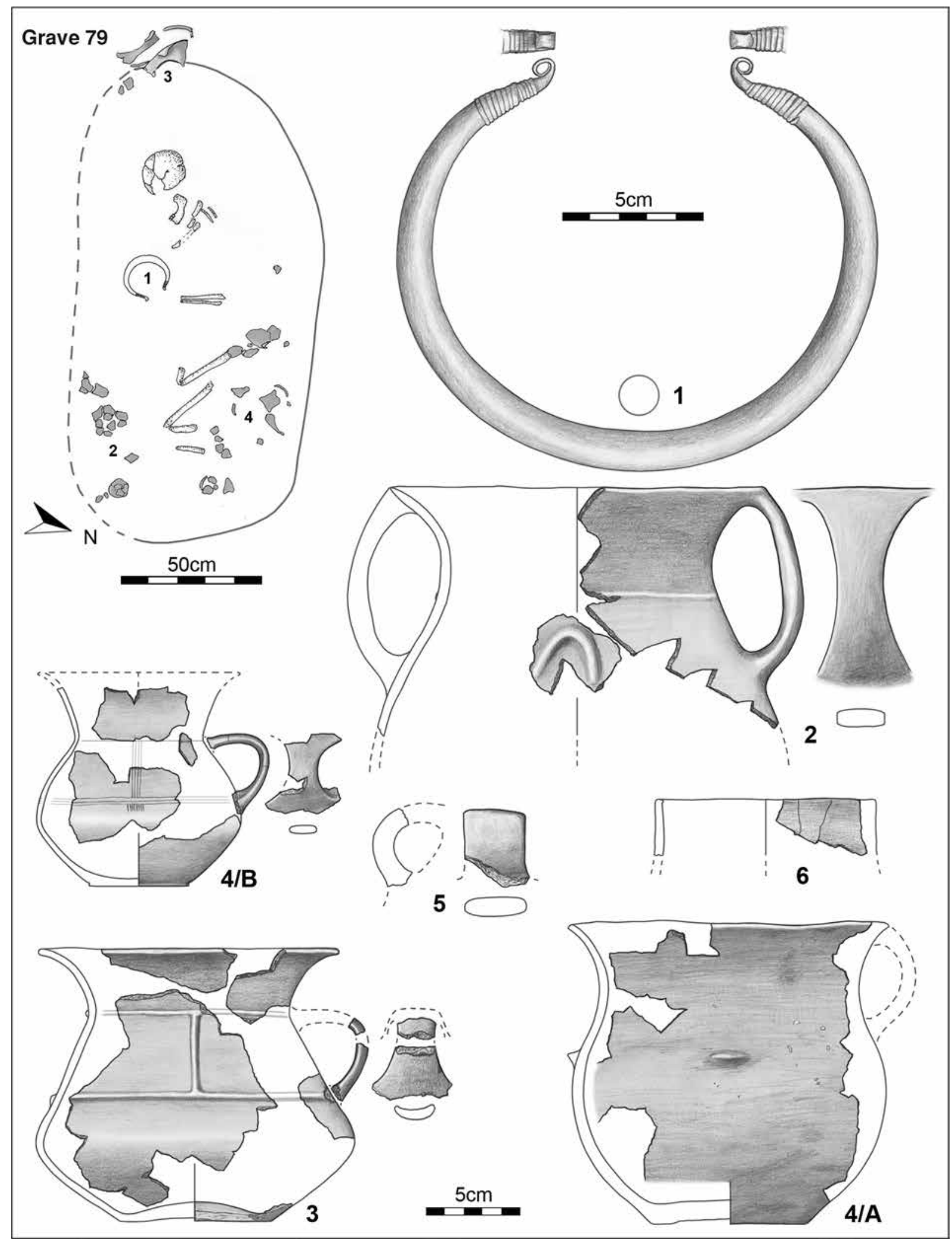

Fig. 24. Nagycenk-Lapos-rét, grave 79 

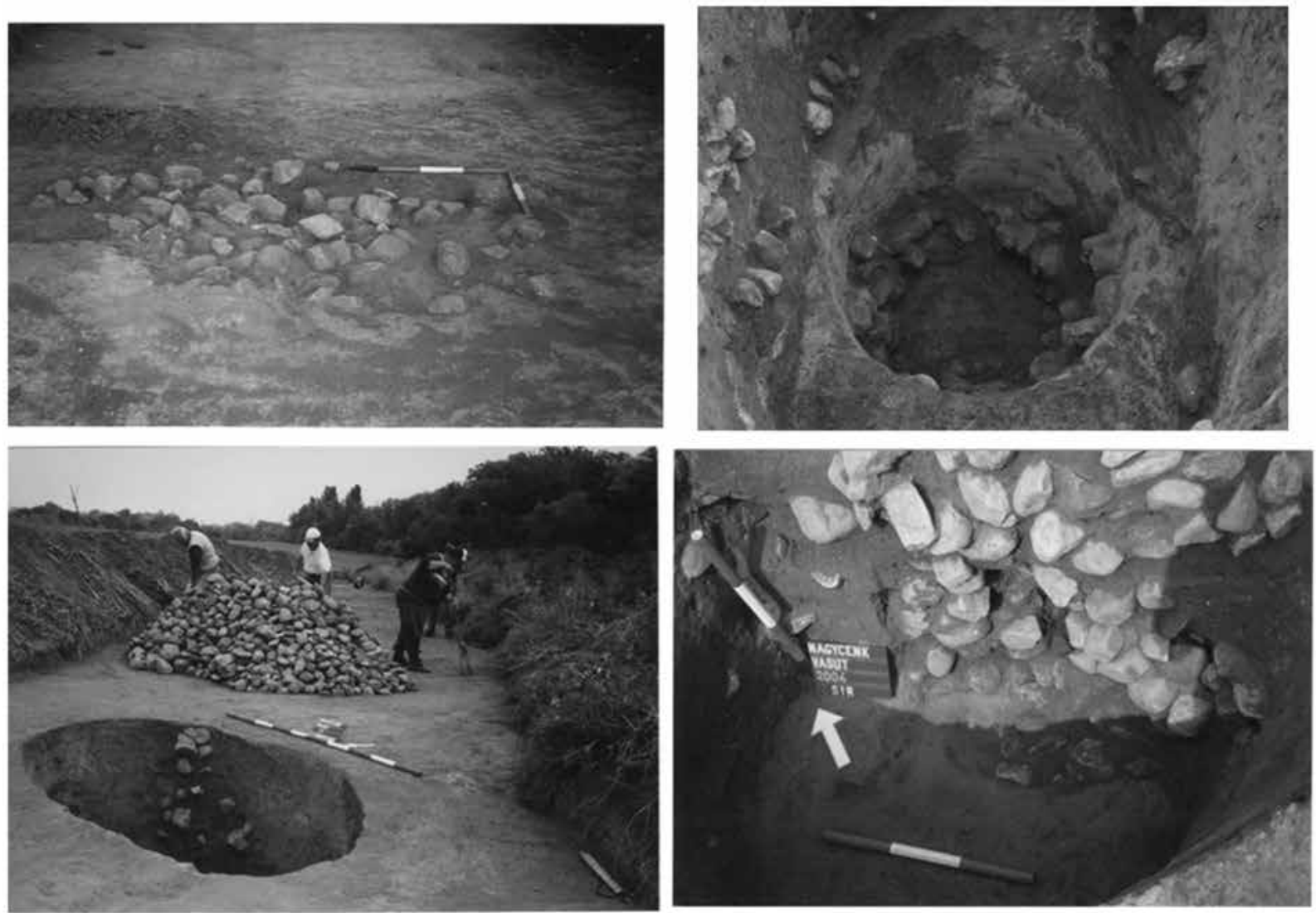

Fig. 25. Nagycenk-Lapos-rét, excavation photos of feature 22

4/A. Double-handled amphora, grey colour with light brown stains, found in the northeast part of the pit, next to no. 2. It has strongly everted rim, curved neck, biconical body. There are two short, round shaped strap handles on the upper part of the vessel. Diameter at the rim: $19.5 \mathrm{~cm}$, Height: $26.5 \mathrm{~cm}$, Diameter at the base: $8 \mathrm{~cm}$, Thickness: 0.5-0.6 cm (Fig. 29.27.4/A)

4/B. Small asymmetrical pot, dark grey colour with light brown stains, found inside no. 4/A. It has everted rim, short funnel-shaped neck. The surface of the ovoid belly is rough, slightly brushed. Height: $11 \mathrm{~cm}$, Diameter at the rim: $9.5 \mathrm{~cm}$, Diameter at the base: $6 \mathrm{~cm}$, Thickness: $0.6 \mathrm{~cm}$ (Fig. 29.27.4/B)

5. Part of a small pot, dark grey with light brown stains, found $12 \mathrm{~cm}$ away from the mouth of $4 / \mathrm{A}$. During the conservation of the finds it turned out to match with no 7. It has everted rim, slightly funnel-shaped neck, slightly biconical body with worn surface, and flat base. The fragmentation on the base indicates that it was hit, which could have broken the vessel into pieces, and eventually both fragments were placed in the pit separately. Diameter at the rim: $14 \mathrm{~cm}$, Diameter at the base: $7.5 \mathrm{~cm}$, Height: $13 \mathrm{~cm}$, Thickness: $0.5 \mathrm{~cm}$ (Fig. 29.27.5,7)

6. Pot, red coloured, with wide, fullel-shaped rim. It is similar to former ones but smaller than vessel no. 1, 2, 3. It is laid on its side. Height: $20 \mathrm{~cm}$, Diameter at the base: $8 \mathrm{~cm}$, Width: $17 \mathrm{~cm}$, Handle length: $6 \mathrm{~cm}$, Width: $3 \mathrm{~cm} .{ }^{20}$

7. The other half of the small pot no. 5 , found $16 \mathrm{~cm}$ away from find no. 6 , to the southwest. It was laid on its side, with its mouth looking southwest.

\footnotetext{
${ }^{20}$ According to the description of the excavation diary.
} 


\section{Feature 22}
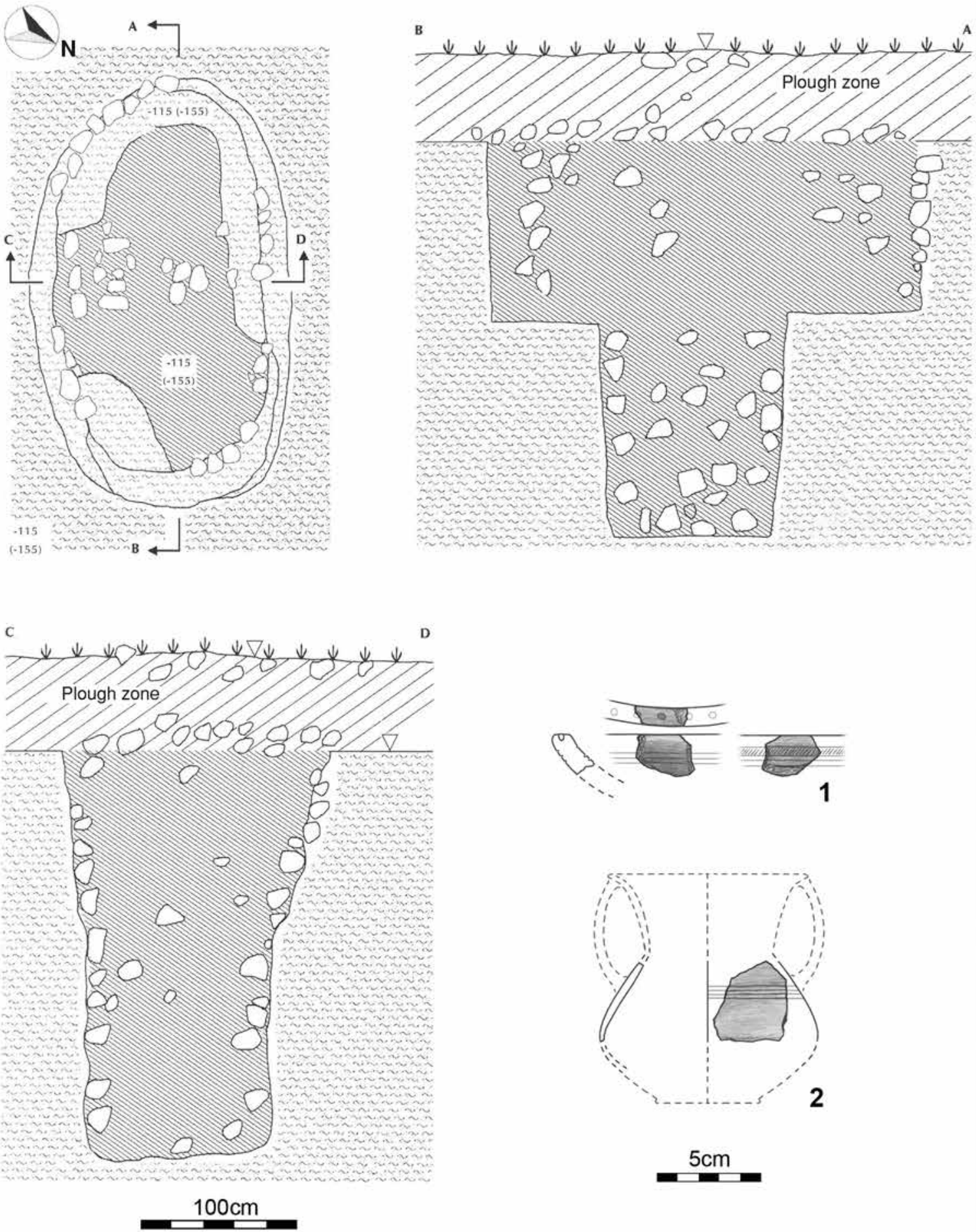

Fig. 26. Nagycenk-Lapos-rét, feature 22 


\section{Feature 27}

A
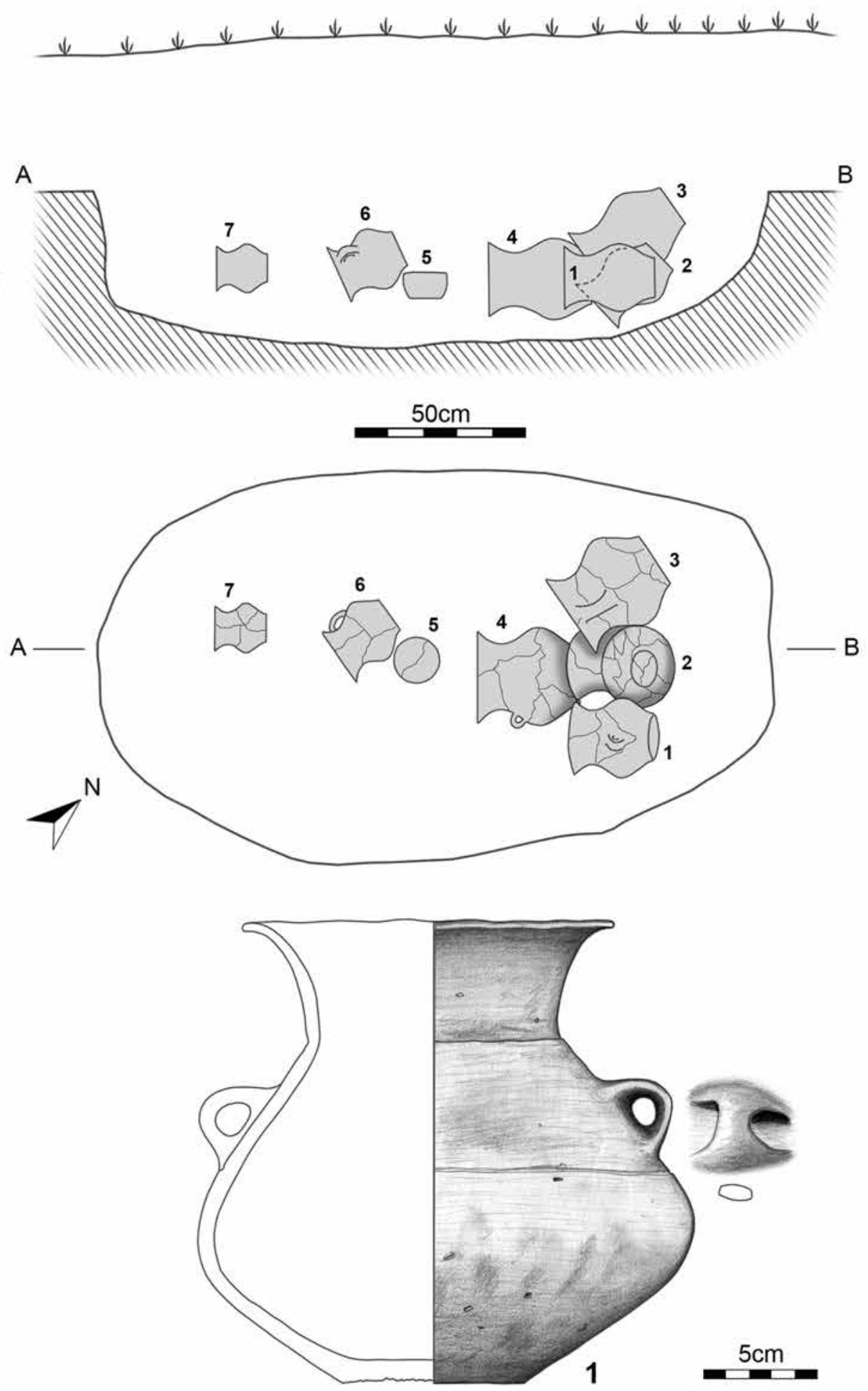

Fig. 27. Nagycenk-Lapos-rét, feature 27 


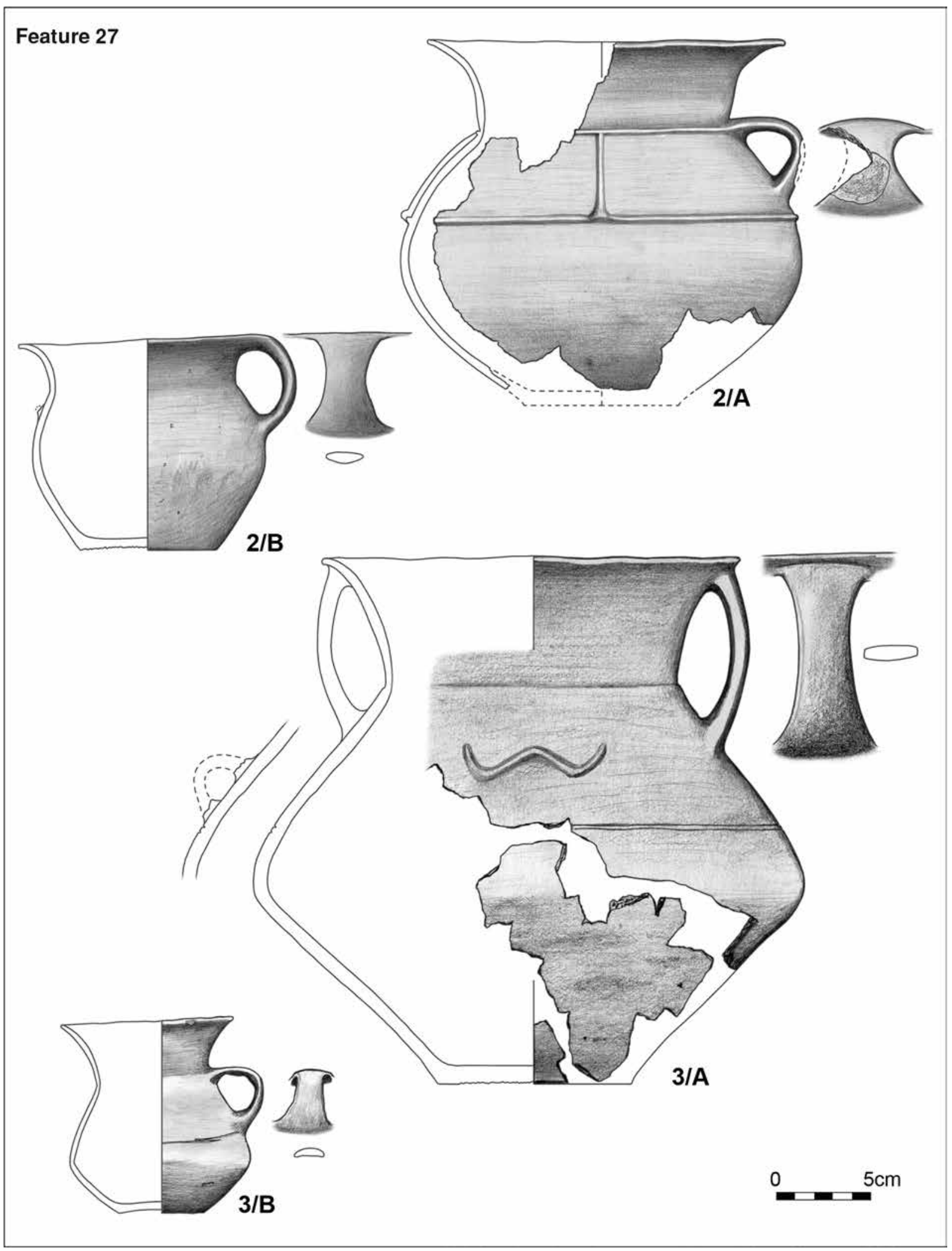

Fig. 28. Nagycenk-Lapos-rét, feature 27 


\section{Feature 27}

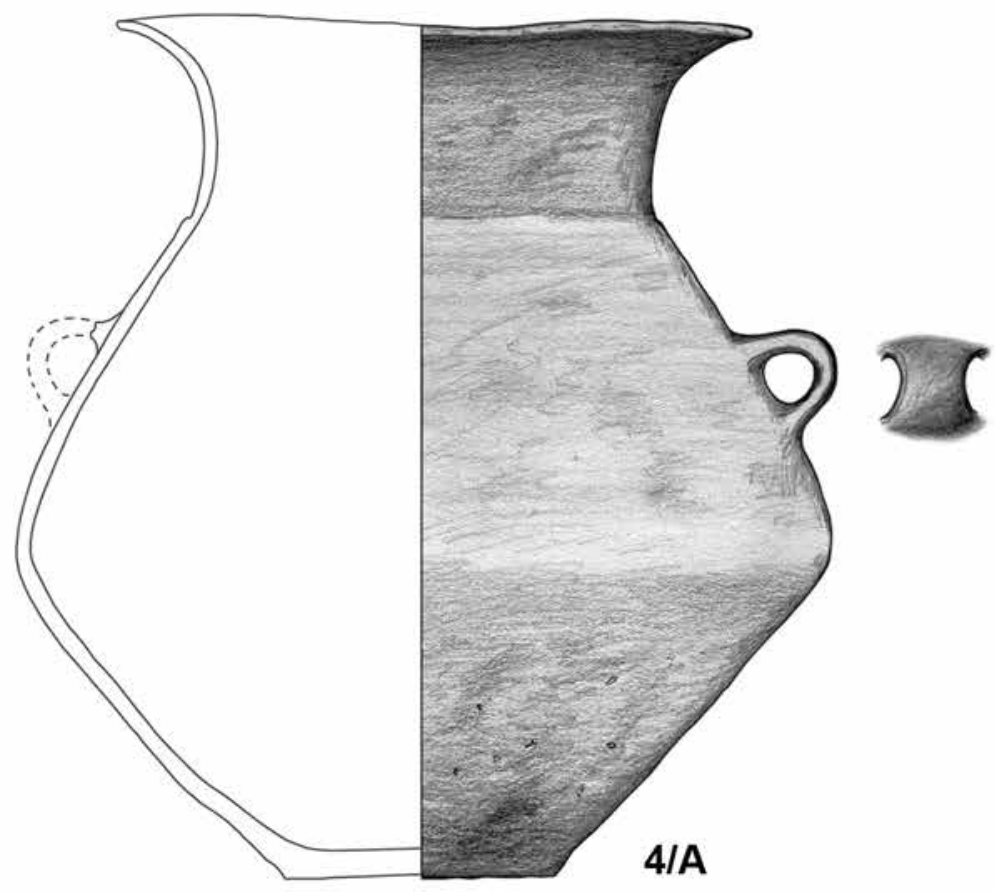

\section{$5 \mathrm{~cm}$}
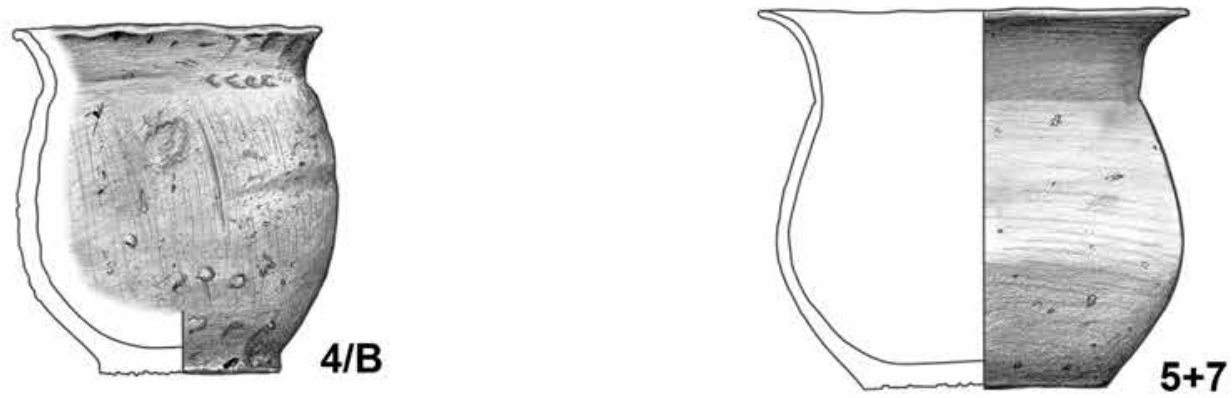

Fig. 29. Nagycenk-Lapos-rét, feature 27 
There were altogether 29 individuals interred in the 27 excavated graves, including two double burials (grave 65 and 66). There were 8 men, 12 women, one adult, 7 children, and the remains of a person of undeterminable age and sex (Fig. 30) in total. ${ }^{21}$ There were also two pits with no human remains in them (feature no. 22 and no. 27), which could have belonged to the cemetery and possibly had ritual functions.

All individuals were buried in flexed or crouched $^{22}$ (i.e. tightly flexed) positions. Most of the time they were laid on their sides and frequently they were laid supine or prone flexed. On some occasions, the bad preservation of the bones made it difficult to identify the exact position of the bodies.

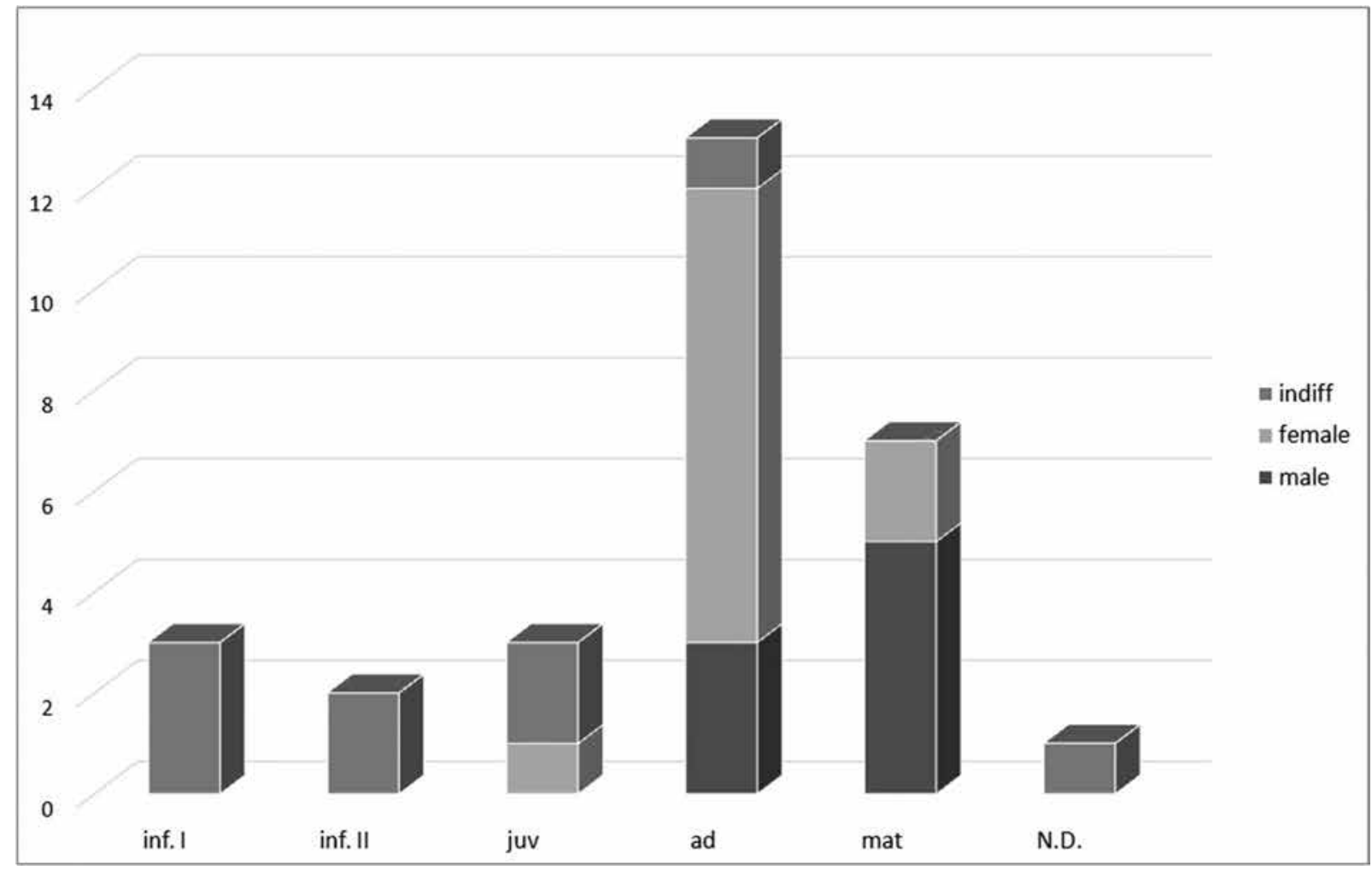

Fig. 30. Age and sex distribution of burials at Nagycenk-Lapos-rét cemetery (N.D. = no data)

\section{Grave pits, and the structural features of the graves and the cemetery}

The grave-pits were ovoid or rectangular with rounded corners. They were oriented SW/W-NE/E. Their large size is remarkable: despite recent disturbances the average size was about $1.5 \mathrm{~m}^{2}$. Not surprisingly, men were buried in larger pits $\left(1.8 \mathrm{~m}^{2}\right.$ on average), while the average size of the graves of women and children was only $1.53-1.57 \mathrm{~m}^{2}$. Those individuals, who were buried with bronze objects of considerable weight were almost always buried in pits larger than $2 \mathrm{~m}^{2}$ (Fig. 31); grave 79 is an exception, though, as the outline of the pit was unclear. Since the bodies were often crouched, the large size of pits may point to the deposition of organic grave goods, which, however, did not preserve due to soil conditions in the Carpathian Basin.

As for the depth of the graves, some were so shallow that it was difficult to identify the outline of the pits (graves $69,74,78$, and 79). The skeleton of a child in grave 59 could be detected right at the level of the scraped surface, but all the other graves were also relatively shallow. Their actual depths (measured from the scraped sur- 
face) varied between 7 and $92 \mathrm{~cm}$; considering the $40 \mathrm{~cm}$ deep ploughzone, which had been removed prior to excavation, their original depths (measured from the surface of the topsoil) fell between $50-130 \mathrm{cms}$. The average value was $27 \mathrm{~cm}$ for men's graves, and $25 \mathrm{~cm}$ for women's graves, and this seems quite low when compared to data from other Gáta-Wieselburg sites in Hungary or at Bratislava-Rusovce, where an average depth of 70-80 cm could be calculated. ${ }^{23}$ At Zsennye, the depth of graves varied between 5 and $100 \mathrm{~cm}$, and below $35 \mathrm{~cm}$ they were considered as "deep". ${ }^{24}$ In case of Nagycenk, this threshold could be set already at $30 \mathrm{~cm}$, as the largest variations occurred around this value.

The man in grave 55 and the woman in grave 54 were both buried the deepest (more than $70 \mathrm{~cm}$ ) with bronze objects of considerable weight and with golden hair rings (Fig. 32). In general there could be a correlation between the weight of the finds and the depth of graves, but there were also exceptions: the individual in grave 79 was buried with a heavy neck ring, but the grave was shallow and disturbed by the plough. One has to take into account also that documented grave depths could vary due to the actual differences in the topography of the sites and to conditions of excavation. ${ }^{25}$ As has been observed during the excavation bones buried deep in sandy layers preserved well, whereas in the upper lying layers of gravelly, reddish clay the state of preservation was worse.

Although grave 1 - of a man with rich grave goods - was not particularly deep, the wooden planks observed above the skeleton indicated that there was a wooden structure inside the pit. In Gáta-Wieselburg cemeteries at Zsennye, Weiden am See (Védény) and Hainburg-Teichtal, there are examples of burials where dead were placed in log coffins, and there were also several coffins found made of oak wood and mounted with handles. ${ }^{26}$ In some cases there were platforms documented, made of wood planks. ${ }^{27}$ Coffined burials were typical for the cemeteries of the Únětice and Unterwölbing cultures in Lower Austria and Moravia. Most of the time there were log coffins observed, and less often plank coffins, primarily in the graves of those individuals, who had higher social status. ${ }^{28}$ In case of the Nagycenk grave, only the remains of covering wooden planks could be observed, which possibly covered the body (and the coffin). Similar examples dated to the same period are known from cemeteries at Velké Pavlovice, Unterhautzenthal and Franzhausen. ${ }^{29}$ As for the Hungarian Middle Bronze Age period a large number of coffined graves $(35 \%)$ was found in the Polgár-Kenderföld cemetery - where the presence of coffins was indicated by the discoloration of the soil around the skeletons -, and at Nižna Mysl'a (Alsómislye). Both sites belonged to the Füzesabony culture. $^{30}$

In grave 56 there were two $20 \mathrm{~cm}$ large stones together with pottery fragments detected at the level of the skeleton as well as above it. This burial can be interpreteted as a phenomenon following the stone pile burial tradition, which is known also from other Gáta-Wieselburg sites around the Lake Fertö and from Hainburg-Teichtal. ${ }^{31}$ The female individual buried in this grave received a special burial treatment as can be assumed from the large vessels deposited in the grave fill above the body.

In the area of Lake Fertö, tumulus burials were frequent in the period of the Bell Beaker culture and during the Early Bronze Age (according to Central European chronology). ${ }^{32}$ Regarding the Gáta-Wieselburg culture, the earlier excavations already revealed the custom of burials in large and relatively shallow barrows (30-40 $\mathrm{m}$ in diameter).$^{33}$ In Nagycenk, however, traces of such features have not been detected, but there were empty areas (with a radius of $5 \mathrm{~m}$ ) around graves 1,55 , and 68 , which is clearly visible on the map of the cemetery (Fig. 2). These zones could be explained probably with some kind of earthen structures on the surface. The graves were arranged within an oval area (25-30 $\mathrm{m}$ in diameter), and their shallow depth would not rule out the presence of barrows, which, however, could have been destroyed later on by intensive agricultural activity and erosion. ${ }^{34}$

\footnotetext{
${ }^{23}$ Melis in print, $a$.

${ }^{24}$ NAGY 2013, 91, Taf. 38.

${ }^{25}$ WAGNER 2005, 133-136.

${ }^{26}$ Krenn-Leeb 2011a, 21; NAGY 2013, 93-94; AspöcK 2015, 35-36, Fig. 4

${ }^{27}$ KRENN-LeEB 2011a, 21.

${ }^{28}$ Bertemes 1989, 34-35; Neugebauer 1991, 72-83; StUChLíK-STUChliková 1996, 135-138; BlesL 2005, 26.

${ }^{29}$ LAUERMAnN 1995, 78, Taf. 24, Abb. 28-30; STUChlíKStuChliková 1996, 135; Neugebauer-MaresCh-NeUGebauer 1997 , 24-26, Abb. 6.
}

Acta Archaeologica Academiae Scientiarum Hungaricae 69, 2018

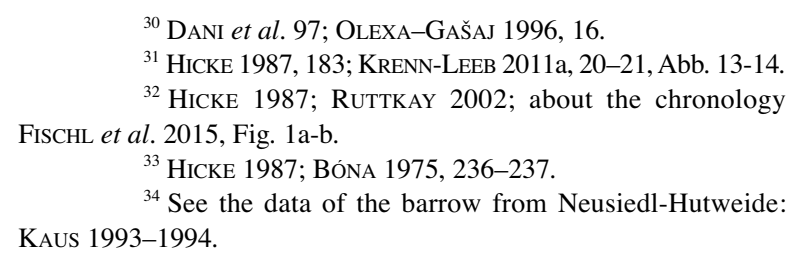




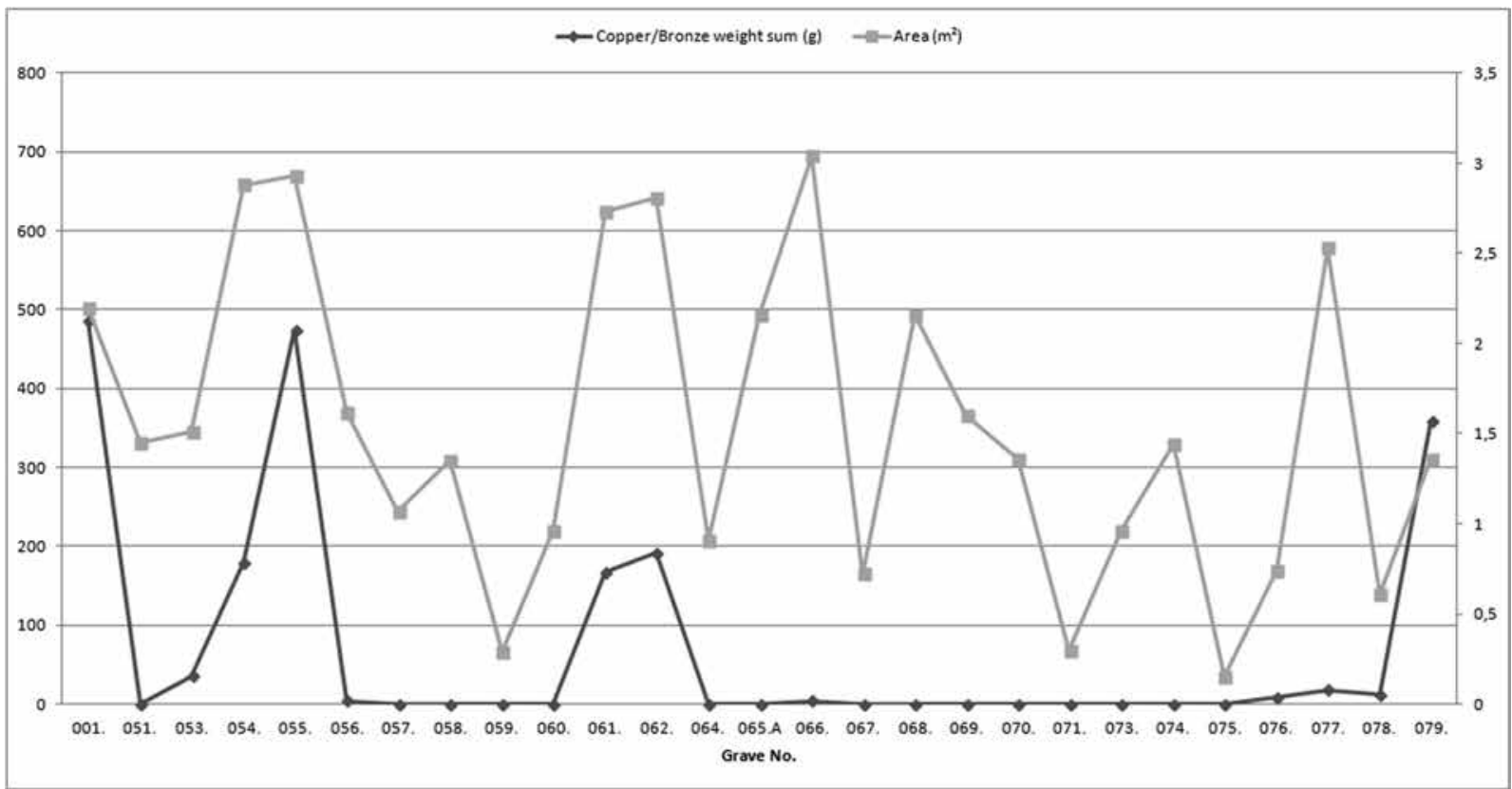

Fig. 31. Association of weight of copper and bronze finds $(\mathrm{g})$ in burials with the size of the grave $\left(\mathrm{m}^{2}\right)$

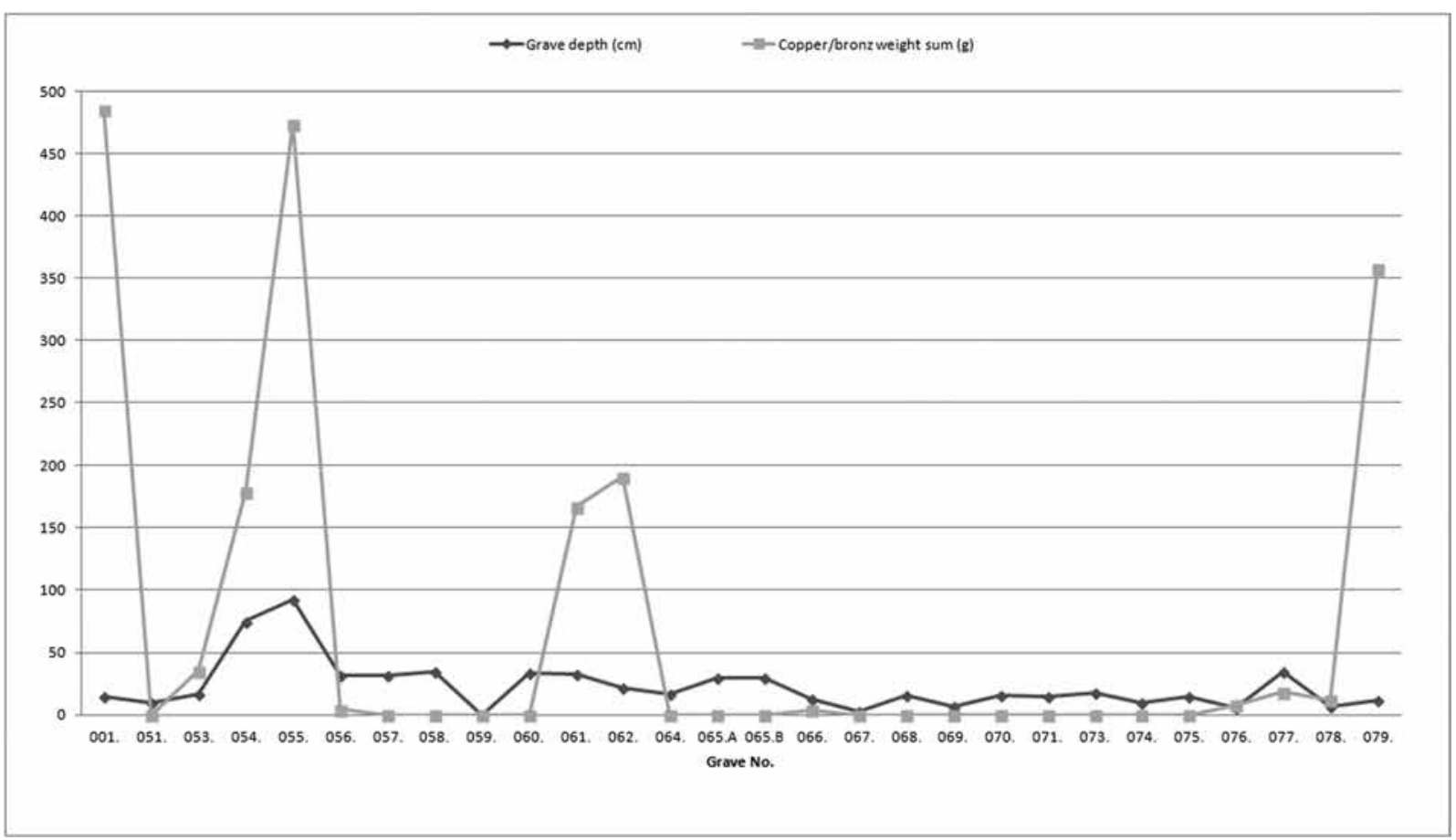

Fig. 32. Association of weight of copper and bronze finds $(\mathrm{g})$ in burials with and the depth of the grave $(\mathrm{cm})$ 


\section{The positions of the bodies}

At Nagycenk all men were flexed on their left sides, or at least their heads and legs were turned to the left, whereas women were most of the time laid on their right sides (Fig. 33).

As has been documented, individuals were not only laid on their sides, but were quite frequently buried supine: there were four men (graves 1, 51, 60 and 69), and three women (graves 65A, 66 and 77) laid on their backs and oriented W-E (only with slight deviation). Considering the W-E oriented supine burials in Gáta-Wieselburg cemeteries, István Bóna suggested steppic influence. ${ }^{35}$ Studies on the Central-European Early Bronze Age and Eneolithic have pointed out that it is, indeed, the cemeteries of the Corded Ware culture and its descendants (e.g. the Nitra culture), where one finds examples for supine inhumation burials oriented W-E. ${ }^{36}$ Contrasting this, burials of the Unterwölbing cultural group, which followed closely the Bell Beaker tradition, were oriented mostly N-S/S-N. ${ }^{37}$ As for the Gáta-Wieselburg cemeteries in Austria, researchers have established that SW-NE orientation was dominant. This conclusion is based primarily on the analysis of the Hainburg cemetery $(n=320)$, which has been investigated since the 1920s. However, burials with different orientations were also documented there (NW-SE, NE-SW, E-W). ${ }^{38}$

Based on a comprehensive collection of graves in Gáta-Wieselburg cemeteries excavated in the early $20^{\text {th }}$, István Bóna concluded that orientations vary between the $\mathrm{S}-\mathrm{N}$ axis and the $\mathrm{W}-\mathrm{E}$ axis (cf. Deutschkreutz) Sopronkeresztúr): NW-SE, SE-NW, SW-NE, E-W; Mannersdorf an der Leithagebirge: NW-SE; Purbach: SW-NE; Wulkaprodersdorf (Vulkapordány) and Mörbisch (Fertőmeggyes): N-S, S-N). ${ }^{39}$ According to the map of a recently excavated cemetery in Weiden am See $(n=226)$, situated on the north shores of Lake Fertö, the graves in the eastern part of the cemetery were oriented approximately SW-NE, while in the northern and southern parts they were mostly N-S/S-N oriented and there were also E-W/W-E oriented ones. ${ }^{40}$ Based on earlier investigations of the Bratislava-Rusovce cemetery - and of other cemeteries in Hungary -, one may argue that the orientation of graves in Gáta-Wieselburg cemeteries situated in the eastern periphery of the distribution area were slightly inclined to the W-E axis. In the excavated part of the Nagycenk cemetery SW-NE orientation could be documented only in a few cases, in case of those graves, where the bodies were flexed and laid on their sides (Fig. 34). Otherwise, the dominant orientation was W-E, with slight deviation towards SW-NE (the heads were usually pointed to $275-250^{\circ}$ ).

The female individual in grave 73 was, however, buried in a reverse orientation (E-W) and she was also laid prone. In graves 54, 55 and 62 there were female and male individuals, who were buried with particularly distinctive bronze objects, and were found also laid prone. The two females in graves 68 and 73 were surely buried prone, similarly to the one in grave 38 in the Hegyeshalom cemetery. In grave 68, only the upper body was laid prone, as if the woman was "kneeling", similarly to the example of a man in the Hegyeshalom-Újlakótelep cemetery (grave 24), laid on his right side. At Hegyeshalom $(n=58)$, there were two females and two males buried prone, their graves were undisturbed, and they had been buried with a few vessels and bronze jewels. ${ }^{41}$ While prone burials at Nagycenk were usually crouched (graves 54, 55, 73), the ones in the Hegyeshalom cemetery were found almost in extended or moderately flexed position.

Prone burials have been considered - especially in earlier archaeological literature - as special or deviant. In the German-language literature their presence have been explained by the primitive fear of the dead coming back - as described in historical documents and in $18^{\text {th }}$ century folklore. ${ }^{42}$ In the Anglophone literature formerly they were seen as a result of natural processes (e.g. decomposition), but later studies argue that these individuals could have had specific social persona in the society. This could be also explained by the non-local origin of the prone deceased. ${ }^{43}$ Concerning some of the above mentioned graves at Nagycenk $(54,55,62)$, it can be also suggested that they were originally flexed on their sides (either left or right), and it was due to decomposition that their bodies were found in prone position. When interpreting variations in burial customs or processes - concerning which archaeological evidence provide only a limited view -, one has to underline the need to scrutinize how "normal" and "spe-

\footnotetext{
${ }^{35}$ BÓNA 1975, 237-238.

${ }^{36}$ Primas 1977, 27, 28; Neugebauer 1994, 60; Neugebauer-Maresch-Neugebauer 2001, 233, 243.

${ }^{37}$ Bertemes 1989; Neugebauer 1991; NeugebauerMaresch-Neugebauer 1997; Neugebauter-MaresCh-Neugebauer 2001, 239.

${ }^{38}$ Beninger et al. 1930; Ehrgartner 1959; KrenN-LeEB 2011a, Abb. 8, Abb. 12.
}

${ }^{39}$ BÓNA 1975, 237-238

${ }^{40}$ SAUER et al. 2012; SAUER et al. 2013; FRANZ et al. 2014;

AsPÖCK 2015, Fig. 2-3; AsPÖCK-BANERJEA 2016, 2-3, Fig. 2.

${ }^{41}$ MeLis in print, $a$

${ }^{42}$ SCHAUB 2009, 6-7.

${ }^{43}$ AsPÖCK 2008, 23-27.

Acta Archaeologica Academiae Scientiarum Hungaricae 69, 2018 


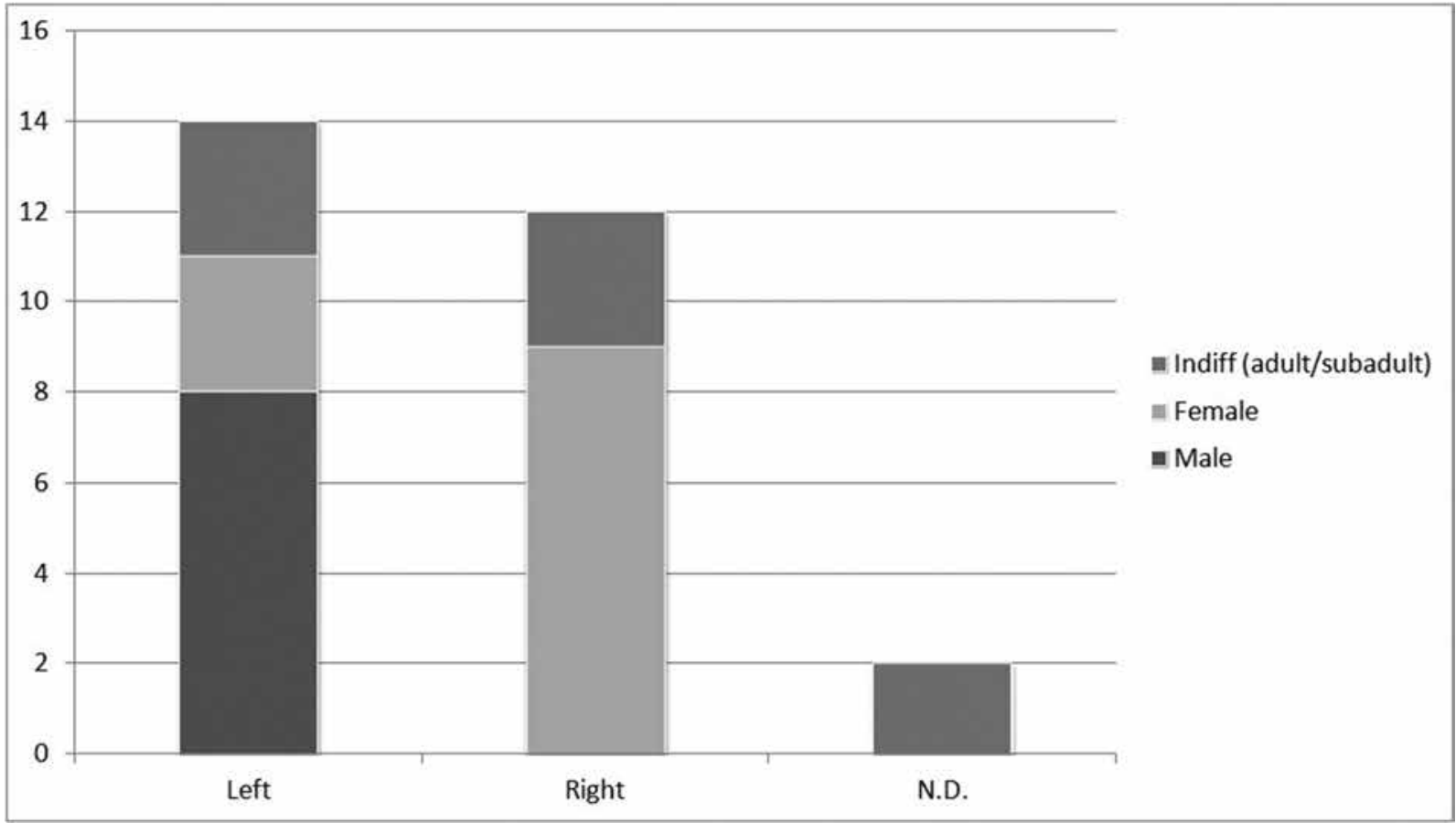

Fig. 33. Variations in the positioning of the bodies by side in association with sex at Nagycenk-Lapos-rét cemetery (N.D. = no data)

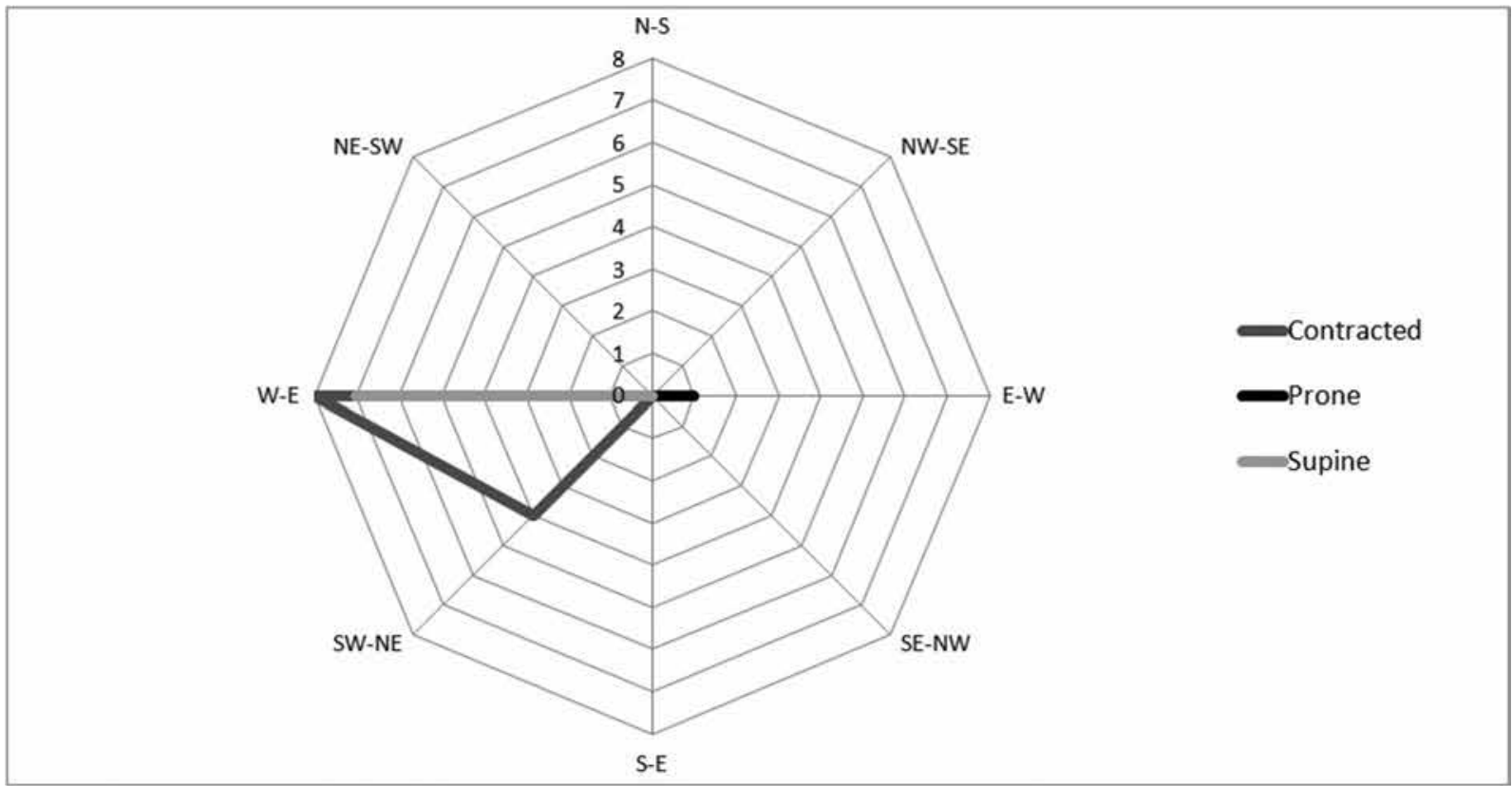

Fig. 34. Variations in the orientation and position of the bodies at Nagycenk-Lapos-rét cemetery 
cial" burials can be distinguished. ${ }^{44}$ With regard to the high ratio of prone burials at Nagycenk (19\%), one has to consider not only issues of taphonomy, but also the fact that the available evidence represents a subset of burial customs practiced by the local community. ${ }^{45}$

The nine documented cases do not reflect a clear-cut pattern, not even when considered together with similar burials at Hegyeshalom. Both women and men could be found in the graves in prone position. In three cases, females were surely buried prone (graves 68 and 73 in Nagycenk, and grave 38 in Hegyeshalom), and in addition to the two $(68,73)$, men of higher social status were also found prone at Nagycenk (graves 55 and 62). However, prone burials did not include children, which is perhaps due to the fact that their bones preserved less well. Except for the one female, who was reverse oriented (grave 73), other prone burials followed the general W/SW-E/NE orientation, just as in other cemeteries. Their grave finds vary from a few vessels (in graves 68 and 73) to heavy bronze and gold objects (grave 54 and 55, with crouched bodies). As regards the spatial location of such burials, they seem to have been positioned in the centre of the oval area occupied by the graves, and except for grave 73 , large spaces were left open around them (cf. Fig. 2). ${ }^{46}$ With regard to the Early and Middle Bronze Age in the Carpathian Basin, a few more examples are known among the graves of the Kisapostag and Maros cultures (Kaposvár: one grave; Mokrin, Ószentiván: three graves), ${ }^{47}$ and similar burials occur also in Slovakia (according to the available publications) dated to the Early Bronze Age period based on Central European chronology. Most of the cases were female burials. ${ }^{48}$

When interpreting prone burials in context, one has to take into account that men and women were usually flexed on the opposite sides, as this was the general custom. (Fig. 33) The male and the female, who were buried with neck rings, crouched, in graves 54 and 55 are good examples of this. The man in grave 62 was laid prone and turned to his left side, in a moderately flexed position. In grave 1 there was a man buried face up, with his legs turned also left - perhaps the legs were originally pulled up straight and later displaced due to decomposition. In contrast, women were laid usually on their right sides. The female in grave 54 was crouched on the right side, and her upper body was laid prone. Similarly, the females in graves 68 and 73 were flexed on the right side and laid prone. Out of the three female burials, who were laid on their left sides (graves 64, 65A, and 66) two were buried in double graves (graves 65 and 66). In grave 65 the male and the female were both flexed on the left. Grave 662 at Franzhausen (I) - a double burial of a 50-70 year-old man and of a younger woman - is a similar example. They were buried in separate coffin, but in the same gravepit and with the same orientation, which was interpreted by the Austrian scholars as a sign of inferior status. ${ }^{49}$ Concluding from here the disturbed flexed burial in grave 79 can be interpreted as a female, as the body was laid on the right side (Fig. 2).

In connection to Early Bronze Age inhumation cemeteries, where most men were buried on their left sides and women were laid on their right sides, the literature underlines the significance of the Bell Beaker tradition. This is evidenced also in case of the Unterwölbing culture and the Böheimkirchen group (Franzhausen I-II; Gemeinlebarn A, F) ${ }^{50}$ Based on the anthropological analysis of materials from the Hainburg-Teichtal cemetery $(n=253), 67.2 \%$ of men were buried on their left sides, and $70 \%$ of women were buried on their right sides. ${ }^{51}$ As for the Hungarian cemeteries of the Gáta-Wieselburg culture and the cemetery of Bratislava-Rusovce $(n=133)$, this pattern is not so clear (the number of men buried on their right sides was higher $60 \%$ (14 determinable male burials). ${ }^{52}$

At Nagycenk the legs were usually moderately flexed. In nine cases the lower legs were crouched, pulled up tightly to the upper body. In case of those burials where the individuals were laid on the sides, the arms were usually bent, in front of the torso, with palms pulled up to the face. This was also common for prone burials (graves $54,55,62$, and 68). In grave 73 the arms were crossed below the belly. In case of supine burials, the arms were folded on the chest (e.g. graves 65A and 69). In grave 1, both hands were pulled up to the left shoulder, with the right arm across the chest. The arms of the young female in grave 77 were positioned in a unique way - pulled up

\footnotetext{
${ }^{44}$ AsPÖCK 2008; AsPÖCK 2013, 35; NotROFF 2011.

${ }^{45}$ AsPÖCK 2013, 27.

${ }^{46}$ Materials from the Hegyeshalom cemetery are currently being processed. Prone burials were rather scattered, and there was no sign of a similar arrangement.

${ }^{47}$ O’SHEA 1996, 170-71; KulcSÁR-Kiss 2016, Fig. 3.5.

${ }^{48}$ BÁtora 2000, 23-24, 41, 257, 479, Abb. 14, Abb. 47,

${ }^{49}$ Neugebauer-Maresch-Neugebauer 1997，26-27, 407-408, Taf. 284-285.

${ }^{50}$ Bertemes 1989; Neugebauer 1991; NeugebauerMaresch-Neugebauter 1997; NeUgebauER-MaresCH-NeUgEbaUER 2001, 239.

${ }^{51}$ EHRGARTNER 1959, 11.

${ }^{52}$ MeLis in print, $b$.
} Abb. 429; BenKovsky-PivovarovÁ-ChropovskÝ 2015, 39, 69, 95, Abb. 30, Abb. 52, Abb. 72. 
to the right side - as if holding an artefact made of organic material between her hands (see below). In summary, the position of legs and arms reflect the patterns observed thus far in other Gáta-Wieselburg cemeteries (based on published materials), and more broadly in Early Bronze Age cemeteries of Central Europe.

\section{Multiple burials}

In the Gáta-Wieselburg cemeteries and in other Early Bronze Age cemeteries in Central Europe, there were usually single burials found in the graves. This applies also to the Nagycenk cemetery, except for graves 65 and 66 . In grave 65 , there was a 23-59 year-old male superimposed directly on the remains of a female (23-29 years old). In grave 66 , bone fragments of a 1-6 year-old child were recovered together with the bones of a 23-29 year-old female. There was probably also a connection between graves 71 and 73, of a 5-7 year-old child and of a 28-34 year-old woman, as they were buried close to each other. In grave 65 , the man and the woman were interred directly above each other, which suggests that the cause of their death was the same (e.g. epidemic or violence) and they died at once or within a short period. Otherwise, it is likely that individuals with close social or family ties were buried together. From Lower Austrian cemeteries - dating from the same period -, there are several examples of women and children, as well as women and men buried together in one grave. ${ }^{53}$ In the Únétice cemetery at Unterhautzenthal there were also children found in the adjacent but disturbed graves of a 35-40 year-old man and of a 17-20 year-old woman. ${ }^{54}$ In Franzhausen in the above mentioned grave 662, there were two skeletons, of a man and a woman, who were buried separately in the same grave, but the position and orientation of their bodies were identical. ${ }^{55}$

In general, archaeological publications of Gáta-Wieselburg cemeteries rarely report about multiple burials. In Hainburg-Teichtal seven examples were mentioned as double burials, and there was also one triple burial. ${ }^{56}$ In Szakony-Kavicsbánya (Hungary) the remains of a 2.5-3.5 year-old infant was identified together with the bones of a 22-25 year-old woman. In grave 4 of the Iván cemetery the bones of an adult and of an infant were found. ${ }^{57}$ There are, however other type of multiple graves, that are also known from Gáta-Wieselburg cemeteries. Altogether five graves were excavated at Szakony, Hegyeshalom, Iván and Weiden am See, where remains of several individuals were documented above each other divided by layers of soil. These can be interpreted as consecutive burials, indicating the re-use of the grave pit. ${ }^{58}$

\section{Positioning of the grave goods}

Apart from the layout and the position of burials it is worth looking at the position of grave goods relative to the bodies. In some cases, when the graves were heavily disturbed by ploughing, it is, however, difficult to find out about this (e.g. in graves 59, 78, and 79).

In some of the graves there were plenty of grave goods, indicating the prominent social status of the deceased, but there were also graves without any grave finds. Gold, copper and bronze jewelries were found usually in situ: the hair rings (both Lockenrings and Noppenrings) were found near the skulls, and the head-band in grave 77 was found on the skull. The neck rings were spotted around the necks of the skeletons, the spiral arm bands were found on the wrists. The two pins were found in male burials, at the left shoulders, pointing up towards the top of the shoulders.

In grave 55 there was a bronze flanged axe, which was fixed into a haft, and the blade was facing the jaw of the skeleton. In graves 1 and 62 daggers were found placed at the waists, and in grave 55 there was also a dagger, found below the ribs and arm bones. The position of the 14 daggers found in the Nitra and Unětice cemetery of

\footnotetext{
${ }^{53}$ REBAY-SALISBURY in print. We hereby thank the author for his kindness to allow us to read her manuscript.

${ }^{54}$ LAUERMANN 1995, 78, Taf. 26.

${ }^{55}$ Neugebauer-Maresch-Neugebauer 1997，26-27,
}

${ }^{56}$ Neugebauer 1994, 64-69; Neugebauer-MareschNeugebauer 2001, 239; AspöcK 2015, 36-37.

${ }^{57}$ MeLis 2017; Melis in print, $c$. We hereby thank Tamás Hajdu, anthropologist, for allowing us to use the data from his forthcoming publication.

${ }^{58}$ ASPÖCK 2015; ASPÖCK-BANERJEA 2016; Melis in print, $c$. Acta Archaeologica Academiae Scientiarum Hungaricae 69, 2018 


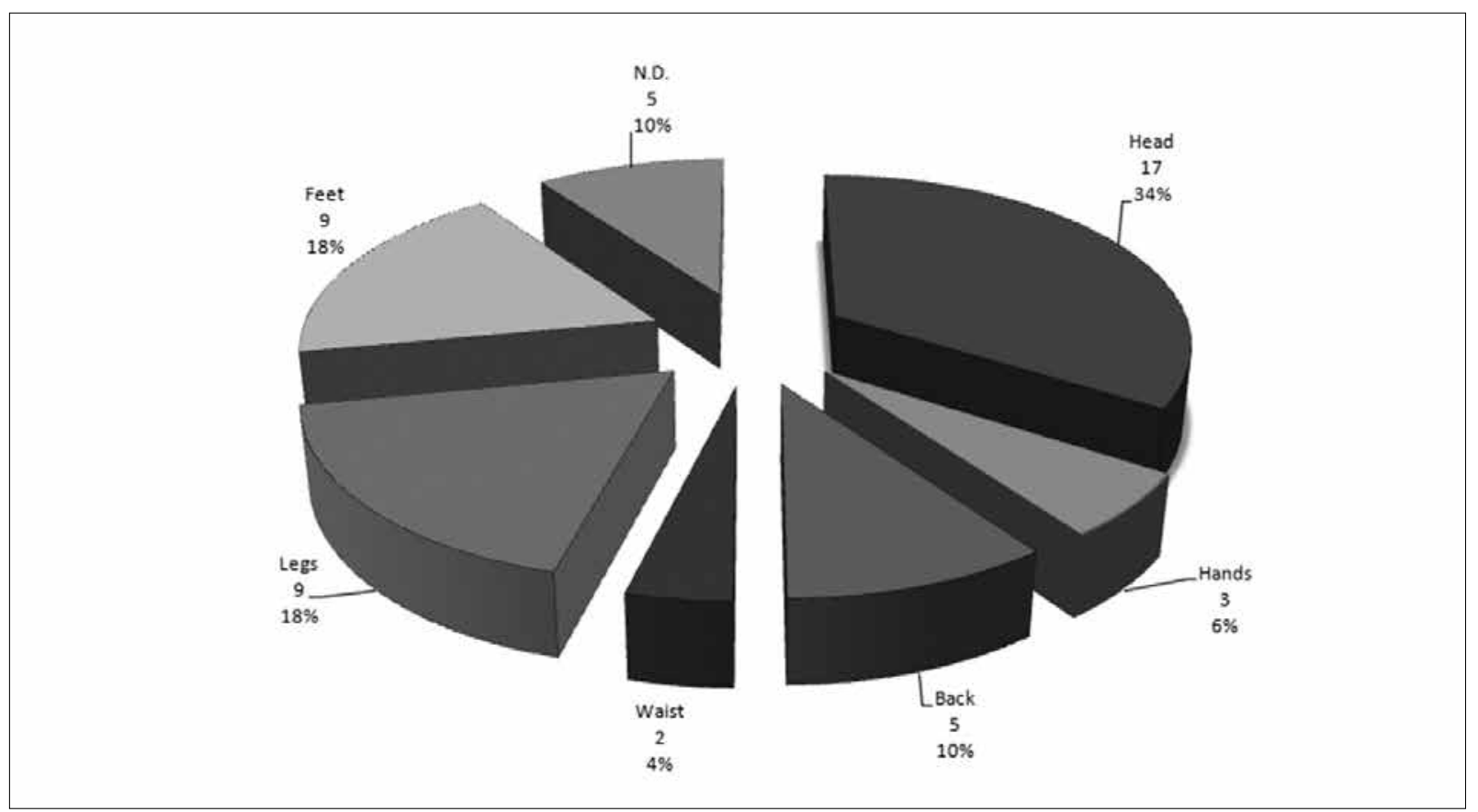

Fig. 35. Association of the position of pottery with zones of the body (N.D. = no data)

Ludanice-Mýtna Nová Ves (Nyitraludány) suggests that placing daggers at the waists and by the arms was common for both cultures. ${ }^{59}$

Burial vessels containing food for the afterlife ${ }^{60}$ were found in almost every grave (20 graves in total). Their positions were evaluated according to the method developed for analyzing burial assemblages of the Füzesabony culture (Fig. 35). ${ }^{61}$ Ceramic vessels were placed in the graves usually at the head, the legs or the feet, and less typically in front of the bodies, at the elbows or the arms. ${ }^{62}$ In grave 66 there were four vessels placed at the back of the body, and in grave 51 there was one found at the scapula. In some graves, there were two or more vessels put inside one another. In the bowls of graves 53 and 62 there was a single-handled mug and a double-handled cup. In grave 54 north of the skull, there was a single-handled mug inside a large amphora with asymmetric handles. The find-context of the four fragmented vessels deposited in this grave, north of the top of the skull, together with other fragments (Fig. 6) is similar to that of another Gáta-Wieselburg deposit found in Szakony (grave 9), which consisted at least seven vessels and a bronze pin. ${ }^{63}$ In grave 56 at Nagycenk there were fragments from large storage vessels and from a pot, all of them damaged, which, however, were deposited in the upper layer of the fill, and not at or above the skull.

\section{Interpretation of non-burial features (well and ceramic depot) in the cemetery}

A few meters from grave 59 an oval pit was found (feature 22). It was oriented W-E, similarly to the graves, however, it turned out that it was filled with stones. Its sides tapered to the bottom, and its shape became

${ }^{59}$ BÁtORA 2009, 252-253.

${ }^{60}$ There were no animal remains in the graves. The archaeobotanical analysis of soil samples is currently underway.

${ }^{61}$ Sørensen-Rebay 2009, 65-67. Because of the low number of vessels found beside the bodies $(n=45)$, typological grouping of the finds would not have been instructive.

${ }^{62}$ A survey on inhumation burials of the contemporary Kisapostag culture - as an eastern neighbour, distributed in the middle Acta Archaeologica Academiae Scientiarum Hungaricae 69, 2018 region of Transdanubia - demonstrated that burial vessels were similarly placed at the head, the feet, and sometimes at the waists (KulCSÁR-Kiss 2016, Fig. 3).

${ }^{63}$ The excavation was directed by Gyula Nováki (Museum of Sopron, Archaeological Archives, 252). The finds are currently being processed by Eszter Melis. 
more circular at $1 \mathrm{~m}$ depth. Its sandy bottom was reached at $290 \mathrm{~cm}$ depth. The feature - interpreted as a well - was filled with layers of stones, each about $10-20 \mathrm{~cm}$ large in diameter. The well must have been deliberately filled as the stones were likely brought here from elsewhere (because similar ones could not be found in this area), or perhaps they were from the structure of the well, which could have collapsed. Mixed in the fill, there was a fragment of an interior decorated footed bowl - characteristic of the earlier Makó culture -, and a fragment of a Gáta-Wieselburg cup was also found (Fig. 26). Based on the short distance from the graves and the orientation this feature could be also part of the cemetery, but its function remains unknown. At Polgár-Csőszhalom there was a Neolithic well found, which had been filled up, in that case, however, this was part of a deliberate, ritual process, as indicated by traces of firing, animal bones, as well as the structured deposition of fragments of special vessel, sealed by a massive layer of daub. ${ }^{64}$ In case of the Nagycenk well it is interesting to see that these many stones were used for the well, but only several stones were used for the graves, despite that this was a rather common practice in case of GátaWieselburg cemeteries.

Feature 27 was situated 10 meters away from the southern edge of the cemetery (to the northwest from it). The orientation of the feature was similar to that of some of the graves (SW-NE), and there were altogether nine vessels found in it. Vessels found in cemeteries, but outside the graves, indicate ritual practices performed at the site as part of memorial services or commemorative events. ${ }^{65}$ Marcella Nagy described a similar depot consisting of ceramic vessels, found at the Zsennye cemetery of the Gáta-Wieselburg culture. There, the pit contained 10 vessels, and it was situated near the central grave of the cemetery, which belonged to the oldest man within that community. It was likely associated with some kind of ritual, or funeral banquet. The pit was apparently used for depositing the storage and serving vessels used for the banquet, including pots, mugs and a bowl. ${ }^{66}$ Feasting often played an important role in rituals connected to liminality, including those performed at funerals. At Nagycenk the vessels found in the feature 27 and the upper fills of grave 56 - some of which were deliberately damaged - point to this practice, too. ${ }^{67}$ The Nagycenk and Zsennye depots were similar also in regard to the types of vessels they were composed of, i.e. storage and serving vessels used for the transport and preparation of drinks and food, as well as during the service performed at the place of the ritual were found in roughy equal numbers. ${ }^{68}$ There were three-three pots for cooking and for the table, and these were accompanied by a small cup at Nagycenk (Fig. 28.27.3/B), and by a bowl decorated with knobs at Zsennye. ${ }^{69}$ In the Nagycenk depot some vessels were elaborate pieces (vessel 2/A, 3/A, Fig. 28.27.2/A,3/A), but there were also ones manufactured by less experienced persons, with uneven finish, and there was also a mini pot made by a child's hand (Fig. 29.27.4/B). ${ }^{70}$ In regard to the shapes of the vessels, the profiles of the amphorae (no. 1 and 4/A) were clearly different from those found in the graves. As for the jug decorated with ribs (3/A), there is no similar example of this type of vessel in such a large size.

Deposition of unique vessels, withdrawn from everyday use, may be indicative of the importance of the ritual act, as well as the prestige of those who took part in it. There were no organic remains found inside the vessels (solid food, or liquid), thus, one may assume that they were buried and destroyed as part of the ritual act, when the food and the drinks had been already consumed. ${ }^{71}$ The destruction and deposition of vessels/fragments symbolizes the notion that these objects - once they had been used in the sacral act - could not be part of the profane world anymore, and they were rather disposed of, as "sacred waste", to avoid profanization. ${ }^{72}$ Also, the deposition of the small pot (without handle) (Fig. 29.27.5,7), which had been broken into two pieces, could be a sign of it becoming a taboo. ${ }^{73}$

Early and Middle Bronze Age ceramic depots from Hungary and Austria turn up either within the area of settlements, or isolated, and primarily contain tableware and sometimes also a significant number of cups. ${ }^{74}$ As for the Gáta-Wieselburg Culture, we know of two depots from Austria: one was found in a small cave at Bad Fischau, consisting six small jugs, and the other one was found at the Siegendorf-2 site and included fragments of several pots and handled pots. ${ }^{75}$ In the area of Bratislava-Rusovce, $500 \mathrm{~m}$ to the southeast from the possible location of the Gáta-Wieselburg cemetery (now a built-up area), there was also a ceramic depot, situated in the vicinity of a sett-

${ }^{64}$ SEBŐK et al. $2013,55-58$

${ }^{65}$ TÓTH 1999, 34

${ }^{66}$ Nagy 2013, 116-117, Taf. 16.

${ }^{67}$ KALla et al. 2013, 13-14. We hereby thank for László Gucsi's observation on the technology.

${ }^{68}$ Kalla et al. 2013, 25-26.

${ }^{69}$ NAGY 2013, 84-85, Taf. 31-33.
${ }^{70}$ FÜLÖP 2016, 124-126, Fig. 5

${ }^{71}$ Kalla et al. 2013, 27-28.

${ }^{72}$ KrenN-LeEb 2010, 293-295; Kalla et al. 2013, 28.

${ }^{73}$ KRENN-LEEB 2014, 28-29.

74 Tóth 1999; Fischl et al. 1999, 99; KRENN-LeEb 2010 , 284-285, Abb. 2

${ }^{75}$ KrenN-LeEb 2010, 302, 313.

Acta Archaeologica Academiae Scientiarum Hungaricae 69, 2018 
lement, as indicated by Gáta-Wieselburg- and Veteřov-type settlement finds. ${ }^{76}$ The composition of this assemblage (five small single-handled jugs buried $60 \mathrm{~cm}$ deep inside a large amphora) resembles to that found at Bad Fischau. ${ }^{77}$

In the area of the Lake Fertö and in the vicinity of Nagycenk ceramic depots also appear in context of the Tumulus culture during the transition period from the Middle to the Late Bronze Age. The one from Hegykő, dated to around $1600 \mathrm{BC}$, was similar to the Nagycenk depot with regard to the number and function of vessels (including serving, cooking and storage vessels). ${ }^{78}$ From the Late Bronze Age there are several depot finds, which contain a significant number of vessels, but this period falls outside of the chronological frame of the present study. ${ }^{79}$

\section{GRAVE FINDS}

There were altogether 35 metal objects -5 gold and 30 copper or bronze objects - in the cemetery. The five gold objects were found in two graves (53 and 55), and there were altogether 13 burials, of both men and women, with bronze objects (Fig. 36). Weapons were found in three graves. Among them, there were two daggers in grave 1 and one dagger and an axe in grave 55. These objects indicated that their owners were warriors, and most of all, high status men.

\section{Dress accessories}

The bronze diadem (or headband) in grave 77 is an exceptionally beautiful piece (Fig. 23.1; Fig. 37.1). The $1 \mathrm{~cm}$ wide, thin bronze band, of which both the top and the bottom edges were decorated by a punched dotted line, as well as X motifs, was found on the forehead of a young woman. The two terminals are spiralled, similarly to neck rings, and they do not connect. The diadem was likely used to decorate the edge of a cap-like headpiece, or was worn as a grip, holding a veil, and tied at the back with a string. Similar pieces are known from the cemetery of the Unterwölbling culture at Franzhausen (graves 110, 747, and 785), which also had spiral terminals and punched edges, but were decorated with geometric patterns ${ }^{80} \mathrm{~A}$ diadem with spiral terminals was found in another Austrian cemetery (Melk, grave 6), and two other examples are from Slovakia (Jelšovce [Nyitraegerszeg], graves 329 and 410). The Melk grave was dated by A. Krenn-Leeb to Phase 2 of the Unterwölbling culture, and the Jelšovce graves were dated by J. Bátora to the turn of the Nitra-Únětice, and to the early Únětice period respectively. Both datings correspond with that of the transitional period from the early and the developed phase of Early Bronze Age in Central Europe (turn of Reinecke A1 and A2) ${ }^{81}$ There is a similar diadem with spiral terminals from the more eastern area of the Vatya culture, in a hoard find at Ócsa, which was dated to the Koszider period. However, the edges of that one were everted and curved, and it was decorated in a different way: with punched circular patterns and with protruding knobs. $^{82}$

There were two types of hair rings documented in the Nagycenk cemetery. In grave 53 there was a gold spiral hair ring made from a double wire (Noppenring), together with another one of similar design, made of bronze (Fig. 5.53.1,5; Fig. 37.2-3). The latter was found close to the hand that was pulled up to the chin, thus, it could be perhaps worn as a ring, but more probably it was decorating the tress. In the excavated part of the Gáta-Wieselburg cemetery at Zsennye there were two such gold hair rings found - in grave 15, of a man, who was the most prestigious individual there -, which were similar in size and form. Gold pieces of this type are known also from the Únětice cemetery in Leubingen. A pair of gold Noppenrings was found in a cremation burial of the Kisapostag culture at Ménföcsanak, these were, however, less elaborate pieces of craftmanship. ${ }^{83}$

${ }^{76}$ BARTÍK et al. 2016, 52, 54, Obr. 2.

${ }^{77}$ Pichlerová 1980, 21-24, Obr. 7, Obr. 8.

${ }^{78}$ ILON 1999, 253-255.

${ }^{79}$ V. SZABÓ 2004; IlON 2012; Kalla et al. 2013, 24-30.

${ }^{80}$ Neugebauer 1994, Abb. 40. 5, Abb 41.1,3-4. In some of the disturbed graves in the Hegyeshalom cemetery there could have been probablyhead ornaments from organic material and bronze, as was suggested by MeLIs 2017.

\footnotetext{
${ }^{81}$ Leeb 1994; Neugebauer 1994, Abb. 4; BÁtora 2000 , 348-350, Abb. 613.37-30.

82 TopÁL 1971, 1973. Earlier head ornaments, known from the Vatya area, are composite head-dresses, made of small wire and sheet ornaments: SZATHMÁRI 1996; MALI 2014.

${ }^{83}$ Schumacher-MatthäUs 1985, 27-34, Taf. 18, Taf. 20; Nagy 2013, Taf. 29.1-2; Melis 2013, Fig. 6; Meller 2014, Abb. 19; ERNÉE 2015, 104-105, Abb. 52.
} 


\begin{tabular}{|c|c|c|c|c|c|c|c|c|c|c|c|c|}
\hline Grave & Sex? & $\mathbf{M}$ & F & $\begin{array}{l}\text { Bronze } \\
\text { diadem }\end{array}$ & $\begin{array}{l}\text { Hair } \\
\text { ring }\end{array}$ & $\begin{array}{c}\text { Neck } \\
\text { ring }\end{array}$ & $\begin{array}{l}\text { Arm } \\
\text { ring }\end{array}$ & Pin & \begin{tabular}{|c|} 
Bronze \\
necklace \\
\end{tabular} & Dagger & Axe & Vessel \\
\hline 1 & & $23-28$ & & & & X X & $\mathrm{X}$ & $\mathrm{X}$ & & XX & & $2+$ \\
\hline 27 & & & & & & & & & & & & 9 \\
\hline 51 & & $36-42$ & & & & & & & & & & 2 \\
\hline 53 & $10-12$ & & & & $X X$ & $\mathrm{X}$ & $\mathrm{X}$ & & $\mathrm{X}$ & & & 2 \\
\hline 54 & & & $44-50$ & & & $\mathrm{X}$ & & & & & & $4+$ \\
\hline 55 & & $37-46$ & & & $X X X X$ & $\mathrm{X}$ & $\mathrm{X}$ & & & $\mathrm{X}$ & $\mathrm{X}$ & $1+$ \\
\hline 56 & & & $51-57$ & & $\mathrm{X}$ & & & & & & & $10+$ \\
\hline 57 & 6-7 & & & & & & & & & & & 2 \\
\hline 58 & & & $32-36$ & & $\mathrm{X}$ & & & & & & & \\
\hline 59 & $8-9$ & & & & & & & & & & & 1 \\
\hline 60 & & $40-46$ & & & & & & & & & & \\
\hline 61 & & $48-54$ & & & & & $\mathrm{X}$ & $\mathrm{X}$ & $\begin{array}{c}\text { Amber- } \\
\text { bead }\end{array}$ & & & \\
\hline 62 & & $32-38$ & & & & $\mathrm{X}$ & & & & $\mathrm{X}$ & & 2 \\
\hline 64 & & & Adult & & & & & & & & & 1 \\
\hline $65 / A$ & & & 23-29 & & & & & & & & & $5+$ \\
\hline $65 / \mathrm{B}$ & & $23-59$ & & & & & & & & & & \\
\hline 66 & $1-6$ & & 23-29 & & XX & & & & & & & 6 \\
\hline 67 & & & $31-40$ & & & & & & & & & \\
\hline 68 & & & $32-38$ & & & & & & & & & 1 \\
\hline 69 & & $36-45$ & & & & & & & & & & \\
\hline 70 & $14-15$ & & & & & & & & & & & $2+$ \\
\hline 71 & $5-7$ & & & & & & & & & & & \\
\hline 73 & & & $28-34$ & & & & & & & & & 2 \\
\hline 74 & & & Adult & & & & & & & & & $3+$ \\
\hline 75 & $\mathrm{x}$ & & & & & & & & & & & 3 \\
\hline 76 & & & Adult & & XXX & & & & $\mathrm{X}$ & & & 1 \\
\hline 77 & & & $17-21$ & $\mathrm{X}$ & & & & & & & & \\
\hline 78 & 15-16 & & & & & & $\mathrm{X}$ & & & & & $3+$ \\
\hline 79 & Adult & & & & & $\mathrm{X}$ & & & & & & $4+$ \\
\hline $\begin{array}{c}\Sigma 29 \\
\text { individ- } \\
\text { uals }\end{array}$ & $\begin{array}{c}7 \text { child } \\
1 \text { adult } \\
1 \text { unde- } \\
\text { termi- } \\
\text { nable }\end{array}$ & $\begin{array}{c}8 \\
\text { male }\end{array}$ & $\begin{array}{c}12 \\
\text { Female }\end{array}$ & 1 & \begin{tabular}{|c|}
5 gold, \\
8 bronze \\
hair \\
rings
\end{tabular} & 7 & 5 & 2 & \begin{tabular}{|c|}
2 bronze \\
1 \\
amber \\
bead
\end{tabular} & 4 & 1 & $\begin{array}{c}\text { Mini- } \\
\text { mum } \\
65 \\
\text { vessels }\end{array}$ \\
\hline
\end{tabular}

Fig. 36. An overview of grave finds from the cemetery at Nagycenk (sex and age determination by Zsuzsanna Zoffmann. Finds description by János Gömöri and Eszter Melis)

The four gold hair rings found in grave 55 were of a different type: tripartite hair rings with thick solid bent ends (Lockenring) (Fig. 9.55.7-10; Fig. 37.4-8). In graves 56, 58 and 66 similar bronze hair rings were found, with thickened bent ends; in grave 66 with thinner variants (Figs 11.56.13, 13.58.1, 17.66.1-2). Also, in grave 76 there were three of these (Fig. 22.76.2-3,5). According to recent research, the main distribution area of bipartite or tripartite gold hair rings with solid, bent ends was the Carpathian Basin. ${ }^{84}$ 
Apart from the high status man's grave at Nagycenk, gold and bronze hair rings could be also found as female dress accessories. The two types of gold and bronze hair rings (Noppenring and Lockenring; Fig. 37.2-8) also appear among the materials of the Gáta-Wieselburg culture (e.g. in Rusovce) ${ }^{85}$ and in the neighbouring Austrian territory of the Unterwölbling culture. Based on the Franzhausen I cemetery J.-W. Neugebauer and Ch. Neugebauer-Maresch dated these types of dress accessories to Phases I and II of the Unterwölbling culture, arguing that similar pieces did not appear in the later period of the culture, represented by the Gemeinlebarn F cemetery. ${ }^{86}$ These jewelry types were used in the Carpathian Basin from the end of the Early Bronze Age and they also turn up in the Koszider period hoards. In the subsequent period, however, newer versions - with parts hammered and embossed to achieve concave ends and a hollow body - appear. ${ }^{87}$

The raw material of the gold hair rings contained $23-27 \mathrm{wt} \%$ silver, with a few trace elements (iron, copper, nickel) ${ }^{88}$ The material composition of the Noppenring from Zsennye was similar: $80 \mathrm{wt} \%$ gold, $20 \mathrm{wt} \%$ silver, and copper could be measured too, as a trace element. As for the gold hair ring found at Hainburg-Teichtal - which was also a Gáta-Wieselburg find - 11-12 wt\% silver content was measured. The material of the hair ring pair found at Ménfőcsanak (Kisapostag culture), contained 18.73 wt $\%$ silver. ${ }^{89}$

Copper neck rings were found in six graves $(1,53,54,55,62$, and 79). Altogether, there were 7 of them (Fig. 37.9-15). All were of the same type: round sectioned, with flat and rolled ends. In the Gáta-Wieselburg cultural area, dating from its older phase, there is a great number of such finds, e.g. in the cemeteries at Zsennye (there were two of them in grave 15) and Hainburg. ${ }^{90}$ Research has established that trading with bronze and copper was important, and this type of object could function also as a measure of value or primitive money, weighing uniformly ca. $160-220 \mathrm{~g}$. This is confirmed by the many depot finds containing exclusively neck rings. ${ }^{91}$ On the other hand, assemblages found in the Nagycenk cemetery (two daggers, two neck rings in grave 1, four gold hair rings, a bronze axe, a dagger, and a neck ring in grave 55), or at Zsennye (two neck rings, two gold Noppenrings and a dagger in grave 15) make it unquestionable that neck rings were also symbols of social status. At Nagycenk, three were found in men's graves, two in women's graves, and there was one in a child's grave. The average weight of a complete neck ring in this cemetery fell in the lower range (within 120 and $170 \mathrm{~g}$ ) of the above-mentioned standard, but in grave 79 there was a much heavier and thicker one, decorated with wires wrapped around the ends $(357 \mathrm{~g})$. Similar neck rings are known from graves 329 and 459 at Jelšovce, and were dated to the Nitra-Únětice phase. The neck ring from grave 15 in Zsennye is also a good example. ${ }^{92}$ Their raw materials have been analyzed in a number of studies, and J. J. Butler pointed out that $85-90 \%$ of the objects found in Austria and Moravia were made of the so called Ösenring copper, while 10-15\% of them were made of pure copper, sometimes with arsenic and nickel impurities. ${ }^{93}$ Non-destructive pXRF analysis of the Nagycenk objects showed no measurable tin in the alloy $(<0.08$ t\%). High values for antimony and silver were, however, characteristic of the Ösenring copper. This copper type, - based on a few lead isotope analyses - can be originated probably from the Slovak Ore Mountains. ${ }^{94}$

Beads made of copper or bronze spiral wires were found in grave 53 (Fig. 5.53.3-4, Fig. 37.16), and fragments of spiral beads were found also in grave 76 (Fig. 22.76.4). As observed during the excavation, they could have been either part of double-strand necklaces, which were hold together by Anatalis (Dentalium) snail shell beads, or they were sawn to the dresses, decorating the parts around the neck. This latter solution was documented

128, Taf. 9.

${ }^{85}$ BÓNA 1975, Taf. 280-281.

${ }^{86}$ RutTKay 1989; Neugebauer-Neugebauer 1989, $127-$

${ }^{87}$ For the latest research on these finds see Kovács 1994; WEIHERMANN 2001; KISS 2012, 117-119; SZATHMÁRI et al. in print.

${ }^{88}$ The pXRF analysis was carried out by Boglárka Maróti (Budapest Neutron Center). The detailed report on the results of this analysis will be published separately.

${ }^{89}$ RUTTKAY 1989; NAGY 2013, 104; Melis 2013. Major components of the alloy are not indicative of its geographical origin. See more details on this by SZATHMÁRI et al. in print.

${ }^{90}$ BÓNA 1975, 282-283; Mozsolics 1967, 70-71; Novotná 1984, 24; LeEB 1987, 257-258; NAGY 2013, Taf. 29.3-4; Duberow et al. 2009, Fig. 3, Fig. 10-11, Tab. 1-2.
${ }^{91}$ Lenerz de WiLde 1995; Sherratt 1997; KRENN-LeebNeUgebauer 1999; LaUermanN 2003, 524-525; VANDKILDE 2005; KRENN-LeEB 2010, 285-286, Abb. 3.

${ }^{92}$ BÁtORA 2000, 351-353; NAGY 2013, 101-102, Taf. 29, 3.

${ }^{93}$ BUTLER 1978, 349.

${ }^{94}$ The pXRF analysis was carried out by Boglárka Maróti (Budapest Neutron Center). Values for antinomy and silver were high, with some lead, but there was no sign of nickel or tin content (cf. Duberow et al. 2009, Tab. 2, Cluster 4), despite the fact that the axe and the dagger, accompanying the neck ring in grave 55 both had a tin content of about $10 \%$. Samples for lead isotope analysis were taken from the neck ring and the daggers (in grave 1) by Ernst Pernicka. The detailed results of this analysis will be published separately. 


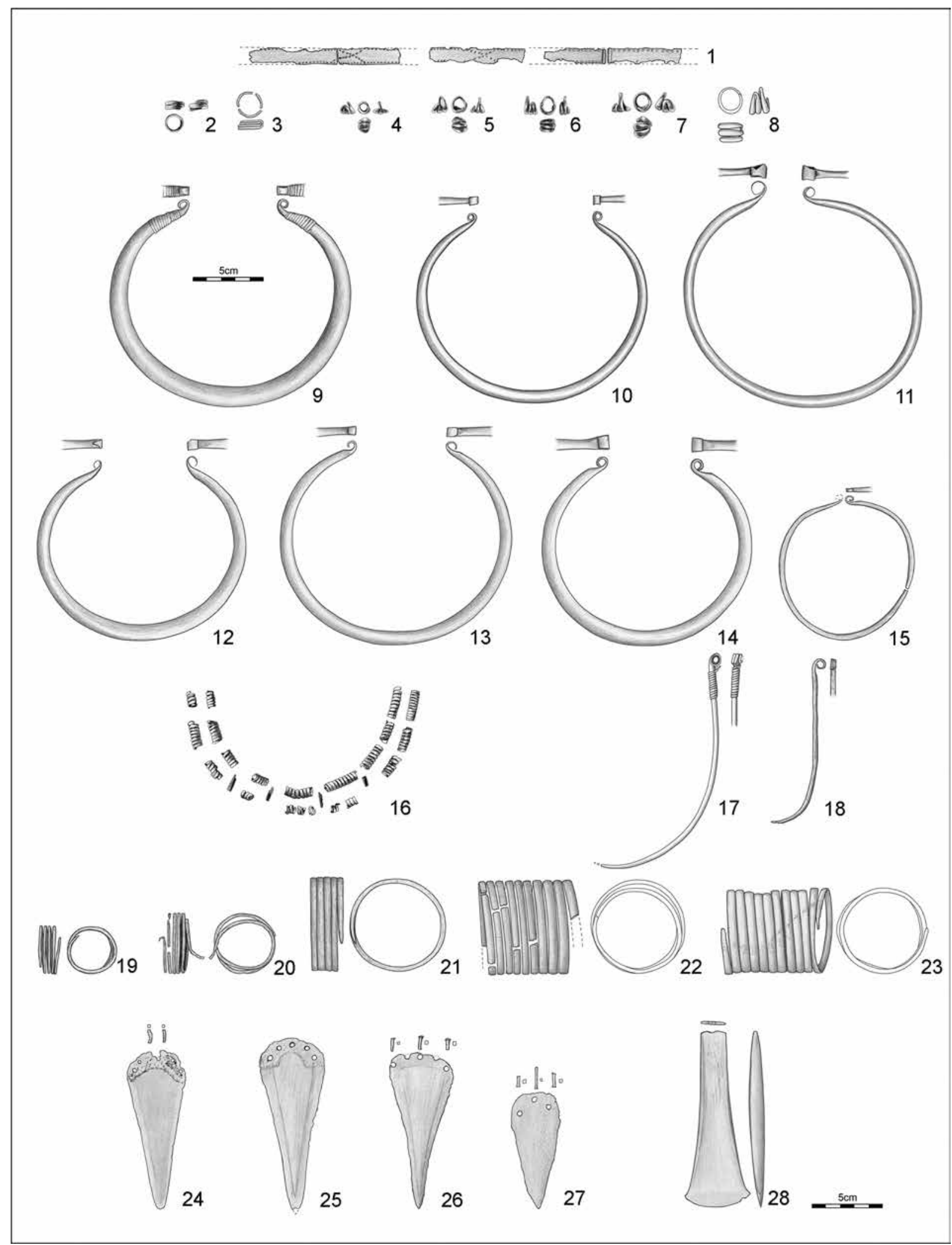

Fig. 37. Typology of the metal grave goods 
also at Franzhausen (in grave 747). Spiral bronze beads combined with amber beads or - in a different composition - with animal teeth and Anatalis (Dentalium) snail shells could be also part of pectoral jewelries. ${ }^{95}$ These simple wire jewelries were characteristic accessories of female dress, but they could be found also in male burials - in the Early and Middle Bronze Age communities of the Carpathian Basin (Vatya and Maros cultures), and in contemporary cemeteries of areas more to the west (Únětice culture). ${ }^{96}$

Bronze spiral arm rings were found in five graves (Fig. 37.19-23). They typically occur in graves of men (graves 1, 55, 61; Fig. 4.1.4, Fig. 9.55.3, Fig. 14.61.1), but also in graves of children (grave 53, of a 10-12 year-old infant, probably a girl; grave 78, of a 15-16 year-old iuvenis; Fig. 3.53.6, Fig. 23.78.1). Multi-spiral arm bands (three bands with 5 turns, one with 10 turns, and one with 11 turns) were common jewelries in the late phase of the Early Bronze Age and in the Middle Bronze Age in Hungary. They can be found in the area of the Únětice and Unterwölbling cultures, in the inhumation or cremation cemeteries of the Kisapostag culture, as well as in the cemeteries of the Maros culture. ${ }^{97}$ At Franzhausen they occur e.g. in female burials with diadems. ${ }^{98}$ In grave 78 at Nagycenk there was a very small-sized example $(3.4 \mathrm{~cm}$ in diameter). A similar sized one was found also at Zsennye, in grave 23 - of an individual, who was also of young age (15-18 years old). Then again, a pair of similar arm bands (3.2 and $3.7 \mathrm{~cm}$ in diameter) survived also at Ménfőcsanak, in a cremation burial of the Kisapostag culture. ${ }^{99}$

The two pins found at Nagycenk were dress accessories of men (Fig. 37.17-18). Both were found in situ, next to the shoulder and the neck (Fig. 3.1, Fig. 14.61). According to earlier studies of the Carpathian Basin, single pins mostly occur in male burials, while pairs of pins can be found typically in female burials, which reflect gender differences in dress habits. ${ }^{100}$ In Central Germany among the Únětice culture burials the number of eyelet pins (Ösenkopfnadel) was observed to correlate with the age and social status of the deceased; pairs of gold pins were found only in the richest, princely graves. ${ }^{101}$

In grave 1, a Cypriot pin (Schleifenkopfnadel) was found (Fig. 3.1.1), which served for holding together the upper dress at the shoulder. This simply wrapped type of pin belongs to the earlier period of the culture. Similar ones can be found in the materials of the Kisapostag (and early Vatya) cultures at Kisapostag and Dunaújváros. ${ }^{102}$ Cypriot pins with side spiral arms were made with a more complex technique of wire wrapping and are dated in the literature to the late phase of the Gáta-Wieselburg culture. These types occur e.g. in the Hegyeshalom, Pusztasomorja and Hainburg cemeteries. ${ }^{103}$ The dress accessories, the jewelries, the dagger and even the burial vessels of the 60-80 year-old man found in grave 322 at Franzhausen II (Lower Austria) were very similar to the finds of grave 1 at Nagycenk (two neck rings, knot-headed Cypriot pin, dagger and bowl). The short bronze daggers from these two graves are almost identical, also with respect to the types of rivets used for fastening the blades to the organic handle. As for the differences, there was another dagger in the Nagycenk grave, and an arm ring, while in Franzhausen, the end of the hilt of the dagger was decorated by a bone disc pommel, and the the man was ornated by bronze spiral beads that were components of a necklace, or sewn onto his dress. ${ }^{104}$

In grave 61, there was a pin with flattened and rolled head (Rollenkopfnadel; Fig. 14.61.2). A similar piece, dated to the end of the Nitra-Únětice period and the beginning of the 'classical' Únětice period was found at Jelšovce. ${ }^{105}$ Also there are similar objects known from more eastern areas, including the cemeteries of the Kisapostag and early Vatya cultures, e.g. at Dunaújváros-Duna-dülö (grave 263). This type of pin was used also in later periods during Hungarian Middle Bronze Age Phase 1 and 2: in the early-classic period of the Unterwölbling culture (Gemeinlebarn Phase II) in the cemetery of Franzhausen (I), and in the Hernádkak Phase A-B; Megyaszó Phase A in the cemeteries at Hernádkak and Megyaszó, which belonged to the Füzesabony culture. ${ }^{106}$ Accordingly, this type of pin can be placed among the latest finds at Nagycenk.

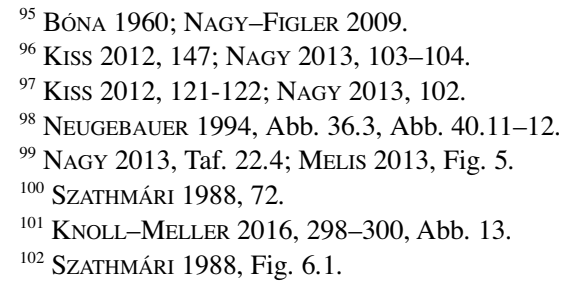

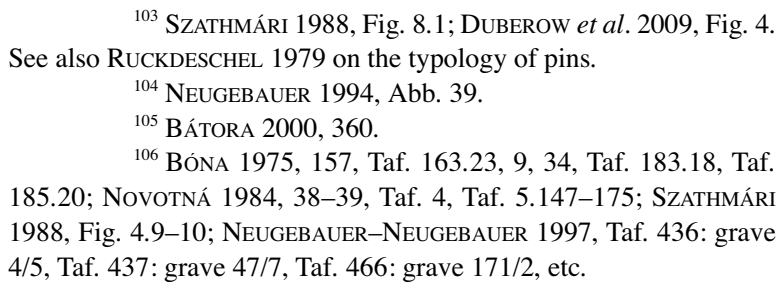

${ }^{103}$ Szathmári 1988, Fig. 8.1; Duberow et al. 2009, Fig. 4. See also RUCKDESCHEL 1979 on the typology of pins.

${ }^{104}$ NeUGebauter 1994, Abb. 39.

${ }^{105}$ BÁTORA 2000, 360.

${ }^{106}$ Bóna 1975, 157, Taf. 163.23, 9, 34, Taf. 183.18, Taf. 185.20; Novotná 1984, 38-39, Taf. 4, Taf. 5.147-175; SzATHMÁRI 1988, Fig. 4.9-10; Neugebauer-Neugebauer 1997, Taf. 436: grave 4/5, Taf. 437: grave 47/7, Taf. 466: grave 171/2, etc. 
In grave 61 there was also an amber bead (Fig. 14.61.3) found beside the roll-headed pin described above. A similar find was recovered from grave 5 in Hegyeshalom, where the bead was accompanied by a Cypriot pin. ${ }^{107}$ According to the field record, this latter bead was likely tied to the hooked end of the pin, decorating and fastening the upper dress at the shoulder. ${ }^{108}$ While this combination - of a pin and an amber bead - was found at Nagycenk in a man's grave, the position of the body in the Hegyeshalom grave, as well as the anthropological analysis both indicated a female burial. ${ }^{109}$ Thus, one may conclude that pins and amber beads could have been used both by men and women as dress accessories.

\section{Weapons and tools}

Copper or bronze daggers were found in three graves (Fig. 37.24-27). There were two of them in grave 1, and there was one in graves 55 and 62 each (Fig. 4.1.5-6, Fig. 9.55.6, Fig. 15.62.2). In all three graves, the daggers were accompanied by neck rings and were status symbols of men. In two cases, the handles were attached to the blades with three rivets. Notably, the number of rivet holes does not provide a clue on how exactly the blades were attached to the hilts, but rather indicates subsequent repairs (cf. the one with 5 rivet holes). On the other hand signs of wear on the blade indicate in some cases the shape of the hilt. In grave 55 organic remains of the wooden or leather sheath preserved intact.

Daggers with 3-6 rivets, rounded hilt plates, and longer triangular blades, were identified as typical finds for the "classical" period of the Unětice culture (Moucha Phase 5; early R Br A2) and contemporary cultures, and their origin was derived from daggers with shorter blades and three rivets. ${ }^{110}$ From the area of the Gáta-Wieselburg culture, two examples are known from Zsennye (grave 13 and 15), which were found in the graves of a 30-40 yearold man and a 50-60 year-old man. ${ }^{111}$ The daggers from Zsennye are good analogies for the thickened, longer blade from grave 62 in Nagycenk. The form of the small, resharpened dagger in grave 1 is similar to the flat, triangular blades of the Nitra culture. ${ }^{112}$ The larger piece from grave 1 is related to the curved, thickened dagger in the Kisapostag settlement near Enese, which could be classified as a"Jelka type" blade. This type is distributed in the early Únětice sites (mixed with Gáta-Wieselburg characteristics) in the territory of Slovakia. ${ }^{113}$ At Nagycenk, a 23-28 year-old man in grave 1, and a 37-46 year-old man in grave 55, as well as a 32-38 year-old man in grave 62 were buried with daggers and neck rings, which reflect their high status within the community. The raw material analysis of these objects revealed that the dagger from grave 1 was made of a copper that did not contain tin, but antimony and silver (as impurities), while the daggers found in graves 55 and 62 were made of bronze with $10 \mathrm{wt} \%$ tin content.

In grave 55 there was also a bronze axe, placed at the shoulder (Fig. 37.28). The flat head of the axe was fixed horizontally into a knee-shaped wooden haft with a forked mounting. It was laid on its side, with the blade facing the area of the chin (Fig. 9.1; Fig. 8). This is an important detail regarding the many uses of these objects. Ötzi, the glacier mummy found in the Italian Ötztal Alps, also had an axe, the $60 \mathrm{~cm}$ handle of which made of yew remained intact in the ice. The orientation of this forked mounting on its handle, however, was vertical (i.e. parallel to the handle), based on which one can assume that that tool was used as an ordinary axe. ${ }^{114}$ Flanged axes are classified typically on the basis of angles of the curved blades. ${ }^{115}$ This one represents an early type, where the blade is less curved, it has a short flang that frames only the "neck" part. Similar finds are known among the finds of the Nitra and Únětice period. ${ }^{116}$

\footnotetext{
${ }^{107}$ The Baltic origins of the amber are being investigated now in the framework of a joint research program with the Adam Mickiewicz University in Poznan.

${ }^{108}$ SZATHMÁRI 1988, 68-69, Fig. 8.9.

${ }^{109}$ SZATHMÁRI 1988; ZOFFMANN 1999, 67.

${ }^{110}$ SCHUBERT 1973; BÓNA 1975, 217, 218; KováCs 1973, 160-162; KovÁCs 1994a, 121; KeMENCZEI 1988, 9-14.

${ }^{111}$ Neugebauer 1994, Abb. 24, Abb. 28; NAGy 2013, 103 , Taf. 27.6-7
}

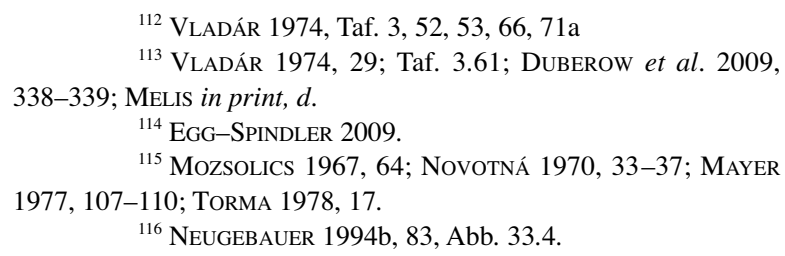




\section{Stone tools}

There were also two lithic finds in the grave of the high status man buried in grave 55: a radiolarite unretouched microblade and a trapezoid, truncated microblade (Fig. 9.55.5,13). There are similar small finds in the western European cemeteries of the Bell Beaker culture, interpreted sometimes as fire-lighting tools (strike-a-light kits), as well as in western Slovakia, in Central European Early Bronze Age cemeteries of the Nitra and Únětice cultures. ${ }^{117}$ The chipped stone blade, fragments and nucleus from the Bronze Age settlement close to the cemetery in Nagycenk imply local stone work. A chipped stone arrowhead, which is characteristic for the Bell Beaker culture, from an excavation near Szombathely could be possibly related to the Gáta-Wieselburg culture. ${ }^{118}$

\section{Pottery}

There were 20 graves with burial vessels. In 11 of them pottery was the only type of grave find. In total 56 vessels were deposited in the graves. Together with the 9 vessels in the pottery depot, there were 65 vessels in the cemetery. Additionally there were small fragments of vessels mixed in the fill of the graves (e.g. in graves 1,54 , 55). Most of the vessels were grey-dark grey, and were burnished. Those with light brown colour and smoothed surfaces were mostly among pots. Characteristically, the lower parts of these pots had uneven surfaces and were decorated with brushing or finger grooves. Notably, such objects occurred mostly in grave 65. The lower parts of the large amphorae, below the carination of their bellies, also had rough, unevenly smoothed surfaces. As for the material composition of the clay it was usually very sandy, mixed with pebbles, grit and mica, often easily disintegrating. Grog did not occur as tempering agent. Even the polished and decorated pieces were sometimes unevenly worked. Signs of wear - due to everyday use - could be found on them too. Some of the vessels were found destroyed due to secondary disturbance (e.g. in graves 78 and 79), but in the ceramic depot as well as in graves 54 and 56 , already intentionally fragmented pieces were deposited. ${ }^{119}$

Most types of vessels documented at the site correspond with the typological categories established in a 1987 study on Gáta-Wieselburg assemblages. In order to provide an overview, the reconstructed forms from Nagycenk are summarized in Fig. 38-39. ${ }^{120}$ In some cases the exact type of the vessel could not be assessed (e.g. in case of finds no. 2-3 in grave 70; or the base of the small pot in grave 59). Tableware for consumption (cups, jugs) or for serving food and drinks (jars, bowls), as well as storage vessels (amphorae) and pots, occur among the finds. When looking for connections between the typological composition of burial vessels and sex and age patterns, some tendencies unfold, however, these should be viewed critically, with regard to the small sample size (Fig. 40). The analysis presented below does not cover materials from the ceramic depot, or from grave 75, and the small sized and unique vessels from grave 56 were also excluded (Fig. 11.56.10,14). Vessels used primarily for storage and cooking (pots and amphorae) were found almost exclusively in female burials. On the other hand, tableware for serving (the double-handled jugs/cups and the bowls) occur more frequently in male burials. Apparently, volumetric measurements would show that the capacity of vessels in women's graves was larger, so there could have been more food and drinks placed in their graves. Among the vessels used for dining, single-handled cups seem to have occurred in female burials. Whether such gender differences in Bronze Age burials are to be observed in regard to other types of vessels, and other Gáta-Wieselburg cemeteries, shall be subject to further examination.

Fragments of vessels described as single-handled cups (Types Leeb C, and Hicke TA1 - TA2; Fig. 38.1-7) according to the Austrian typological classification were found in four graves $(70,74,78,79)$ - where probably women as well as children were buried -, and also in the ceramic depot (feature 27, 2/B). The small cup (find no. 2) in grave 74, which has a curved profile, can be classified as C1 (TA1) subtype (Fig. 38.1). In grave 3 at Iván there

\footnotetext{
${ }^{117}$ BÁtora 2000, Abb. 594,18, Abb. 618,44; FizTPATRICK 2011, 209; TEATHER-CHAMBERLAIN 2016.

${ }^{118}$ Horváth-WiLd 2017, 105, Fig. 6.2.

${ }^{119}$ Petrographic examination of samples $(n=54)$ from the settlement and from the cemetery has been conducted by Attila Kreiter and Péter Skoda (Hungarian National Museum, Laboratory

for Applied Research). László Gucsi, professional potter, has examined the finds from the point of view of production techniques and signs of wear. We hereby thank for their useful contribution. Observations concerning production techniques and use will be discussed in a separate paper. 


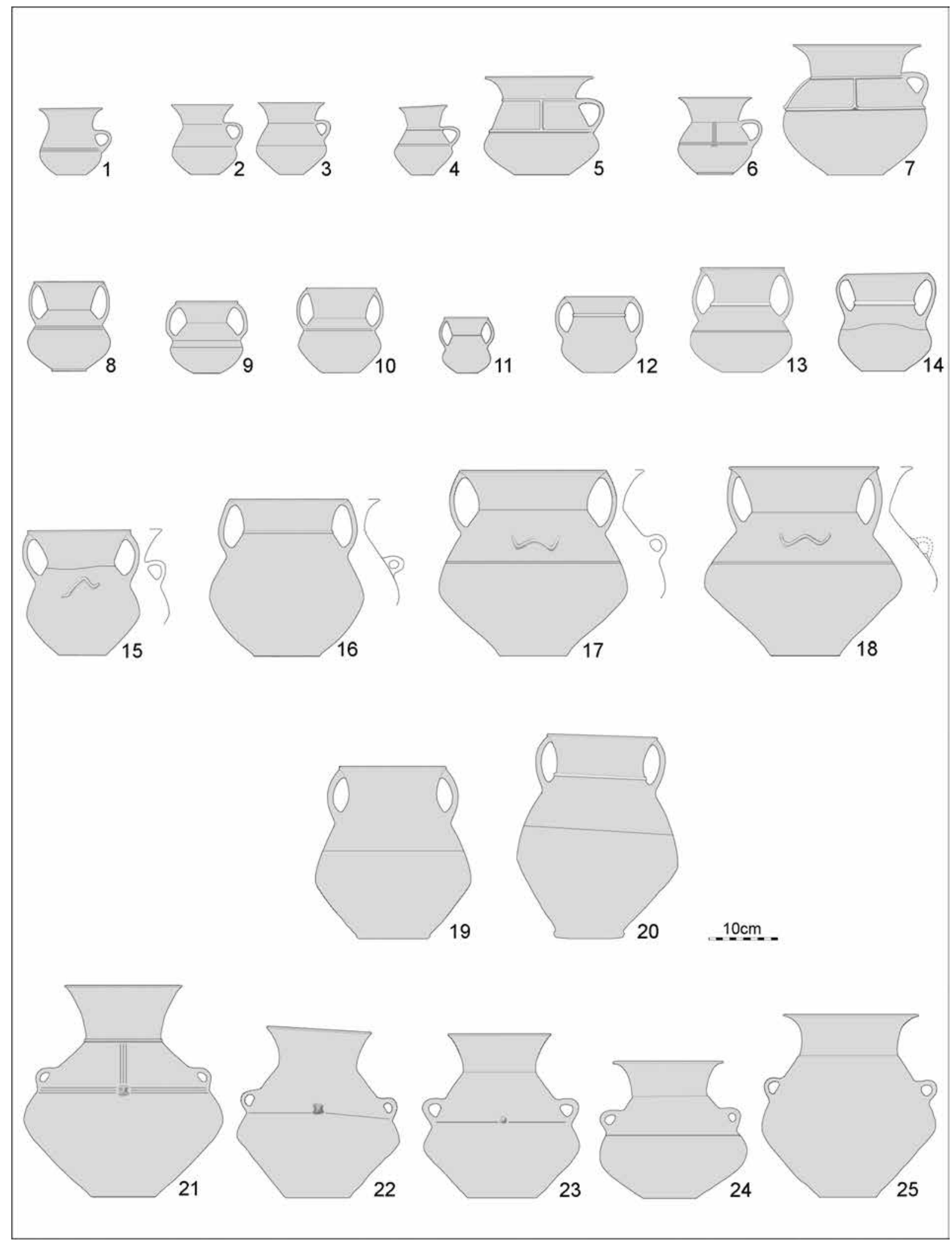

Fig. 38. Typology of pottery from the graves I 
was a similar vessel. ${ }^{121}$ Among the materials of the Gáta-Wieselburg culture published thus far, there are examples of similar cups, in grave 7 at Bratislava-Rusovce, with a slightly more curved neck. Similar variant occurs in the Únětice culture cemetery of Vel'ký Grob (Magyargurab), where Gáta-Wieselburg pottery forms are also found. ${ }^{122}$ The $\mathrm{C} 1$ subtype can be dated to the early phase of the culture, and the ones from the Bratislava-Rusovce site are described as the earliest finds in the assemblage. ${ }^{123}$

Find no. 1 with articulated profile in grave 70 is a characteristic example of the C3 subtype (Fig. 38.4). Find no. 2/B in grave 78 (Fig. 38.3), and find 3/B in the ceramic depot (feature 27, Fig. 38.2) are both a version of this, but with wider and lower seated belly. ${ }^{124}$ In addition to Gáta-Wieselburg cemeteries, there is also a similar find from a Nitra culture burial found at Branč. ${ }^{125}$ Find no. 3 in grave 79 at Nagycenk (Fig. 38.5) is a version of this latter, biconical type, with a lower seated belly.

The closest parallel of find 4/B in grave 79 (Fig. 38.6) at Nagycenk - in terms of shape and decorative arrangement - is a vessel found in a female burial (grave 17) at Jois (barrow II). ${ }^{126}$ Find 2/A (Fig. 38.7) in the ceramic depot, a large jug with a globular body, is, in fact, a large-sized version of the $\mathrm{C} 2$ subtype. It is this form which occurs usually in large sizes. ${ }^{127}$

The yellowish brown cup with one long handle (Fig. 39.3), found in grave 73 (a reverse oriented prone burial of a female), was much different from other vessels in the cemetery of Nagycenk (they were usually greyish), and its form - as well as the texture of the clay - also differed from that of any other type of vessel characteristic for the Gáta-Wieselburg culture. Similar biconical cups, with sharp carination on their belly parts and with almost concave lower parts, also occur among the materials of the Somogyvári-Vinkovci culture in Transdanubia. They usually have a long cylindrical neck, but it is the one found at Nagyvejke (Southwest-Hungary), with shorter neck and a small spout, that resembles the most to the one found at Nagycenk. ${ }^{128}$ Fragments of this type could be identified also in the burials of the Makó-Kosihy-Čaka culture, including, for example, a vessel from Kajárpéc-Pokolfadomb (in Northwest-Transdanubia), which had a more cylindrical neck. ${ }^{129}$

A jug, similarly biconical and with a short neck, was found also in one of the Corded Ware burials at Franzhausen (I). ${ }^{130}$ In context of the Corded Ware culture, the so called "Balkan-type, Nagyrév jugs" found in the Moravian cemeteries (Kloboučky, grave 1; Krumvír, grave 7; Kyjov-Nětčice I, grave 1; Letonice, barrow no. 3 and 4 ) are the closest parallels (in regard to the form) to the cup found in grave 73 at Nagycenk. ${ }^{131}$ The southern shore of Lake Ferto" is situated at the geographical centre of the distribution areas of Early Bronze Age (Eneolithic) biconical cups, i.e. situated between Transdanubia and the Traisen valley in Austria (e.g. Franzhausen I).

'Classic' type of double-handled jugs characteristic for the Gáta-Wieselburg cultures (Types Leeb A, and Hicke TA4, Fig. 38.8-14) were found in seven graves at Nagycenk. Four of them were male burials $(1,51,55,62)$. In a double-grave (grave 65) it was similarly the male individual (skeleton B), with whom this type of vessel was buried (next to his knees). Grave 66 was a female burial, but the skeleton was laid on its left side, similarly to men. In grave 57, of a child, a small-sized version of this vessel type was found.

According to the typological classification established in 1987, there are two variants of the type: the one is Type A1, with a low centre of gravity, and a less pronounced lower part, to which the cup in grave 57 (Fig. 38.11 ), and the jug in grave 66 (Fig. 38.12) belong. ${ }^{132}$ This type was also found at Zsennye, in the grave of a young adult. ${ }^{133}$

In contrast to Type A1, the other variant, Type A3, has a more articulated profile, and its lower part is more pronounced. There is an elaborate example found in grave 55 (Fig. 38.8), and the biconical profile of the jug in grave 62 (Fig. 38.10) also connects to this variant. Type A2 is a transition between the two variants, represented by a vessel with a globular lower part, found in grave 65 (Fig. 38.9), and by the jugs in graves 1 and 51 (Fig. 38.13-14), which had a lower center of gravity and more curved necks. ${ }^{134}$ The two outstandingly rich graves of men both had

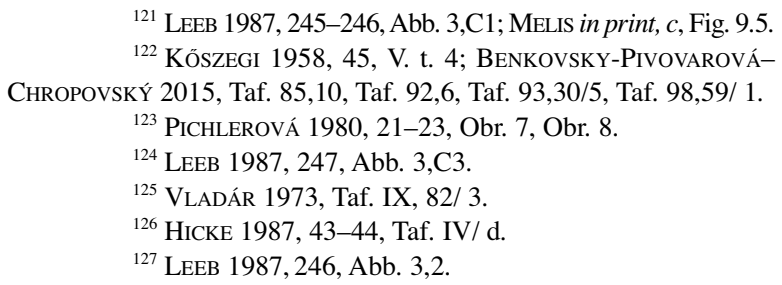

${ }^{128}$ Kulcsár 2009, 279-280, Fig. 48,I/9, Pl. 48,1.

${ }^{129}$ Figler 1996, III. t. 4; KulCSÁr 2009, Fig. 19.

${ }^{130}$ NeUGEBAUER-MARESCH-NEUGEBAUER 1997, 197, Taf. 478,2.

131 ŠEBELA 1999, 72, 82, 84-85, 86-89, Pl. 28,4, P1. 34,2,

Pl. 37,1, 3, Pl. 40,7, Pl. 41,2

${ }^{132}$ LEEB 1987, 241, Abb. 3,A1.

${ }^{133}$ NAGY 2013, Taf. 34, 4, Taf. 35,2.

${ }^{134}$ LEEB 1987, 241-242, Abb. 3,A2,A3. 


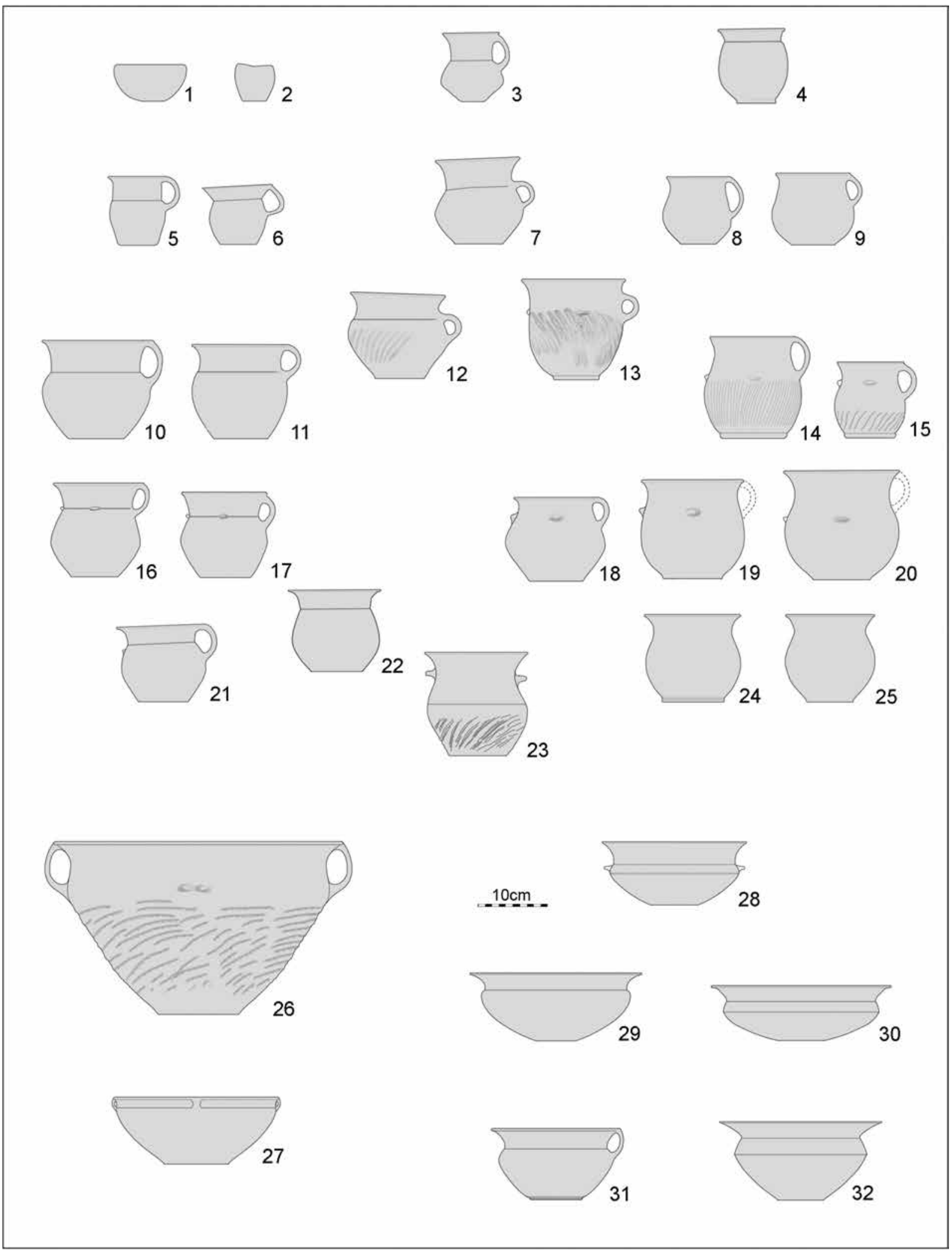

Fig. 39. Typology of pottery from the graves II 
an early dating, while the elaborate biconical form of another one found in the ceramic depot (feature 27) suggests a later date.

At Nagycenk amphorae with short handles (Types Leeb D2 and Hicke THG 2) are represented by variant with two handles. In grave 56, fragments of at least three biconical amphorae (with a knob handle in-between two short handles on them) were found (Fig. 38.21-23). In comparison to other (published) Gáta-Wieselburg assemblages, find no. 1 in grave 56 (Fig. 38.21) was a unique piece, decorated with bands of incised lines. The upper parts of similar amphorae found at Bratislava-Rusovce were rather decorated with ribs, while bands of incised lines were rather used to decorate vessels with asymmetric handles. ${ }^{142}$ A similar amphora, with narrow neck, was found in the cemetery at Hainburg. ${ }^{143}$ The parallels of the other two amphorae from grave 56 (Fig. 38.22-23), which had sharp carinations on their belly (but relatively lower) are known from a depot in Zsennye, ${ }^{144}$ and from the barrows in Oggau and Jois. ${ }^{145}$ Find no. 4/A in the Nagycenk depot (feature 27), had a more everted rim, and sharp carination on the middle part of its belly, similarly to find no. 1 in the same depot (Fig. 38.24-25). A vessel of similar form was found in grave 937 (of a man) at Franzhausen (I) and the forms of the two amphorae with short handles found in the depot (feature 27) also point to connections with the Unterwölbing culture. ${ }^{146}$

Finds no. 10 and no. 14 in grave 56 (the original position of the latter is uncertain) were small, not well elaborated vessels, a jar and a bowl (Fig. 39.1-2), for dining, and they were most probably made by an apprentice potter - a child perhaps. ${ }^{147} \mathrm{~A}$ similar bowl was found in Bratislava-Rusovce in the grave of a 5-year-old child, buried with a horse skull. ${ }^{148}$ Small bowls, of rude finish, could be often found in the graves of children and young adults also in the Franzenhausen (I) cemetery. ${ }^{149}$ At Nagycenk, however, the individual in grave 56 was a 51-57-year-old female - perhaps these vessels were representations of members of the community, who buried her (including children and descendants).

Fragments of pots and jars (Types Leeb J, H, Hicke T1, TH 1, TH 2; Fig. 39.4-25) were found at Nagycenk in the highest numbers. In total 23 fragments were found in 12 graves and the ceramic depot (feature 27). Different versions were found - with knobs, with a single handle and without handles -, and they could be used for dining and cooking. Except for the double grave (65), there were all in women and children graves. In children's graves there was one pot in each (graves 64, 68, 76, 79), in women's graves $(54,56,66)$ there were three of them in each. In the ceramic depot there was also three pots: one with a handle, the other without handle, and the third one was miniature and unevenly worked (Fig. 39.4). It is sometimes uncertain because of fragmentation how many handles or knobs the vessels originally had. Although the Austrian typological classification is based on whether the vessels had or had not handles, we thought it more instructive to sort the pots into categories according to their profiles.

Pots and jars with articulated profiles (Types Leeb H3 and Hicke TH 1) with sharp carnation between the neck and body parts almost always had only one handle. The height of these vessels is between $10-15 \mathrm{cms}$. With small variations they correspond to Type $\mathrm{H} 3$, and often there is a small knob on the shoulder, opposite the handle (find 2/B, in feature 27, Fig. 39.21). ${ }^{150}$ The small pots found in graves 54 and 56 (Fig. 39.16-17), the necks of which were emphasized by a line running around, as well as by small oval knobs, have examples also in other GátaWieselburg assemblages found at Bratislava-Rusovce and Oggau. ${ }^{151}$

Small pots with round shaped handles, were found in graves 66 and 64, sitting on their upper belly parts (Fig. 39.7.12). They were different from the finds characteristic for other Gáta-Wieselburg cemeteries and stylistically closer to the types found in the graves of the Unterwölbing culture, in the cemeteries of Gemeinlebarn and Franzhausen. ${ }^{152}$

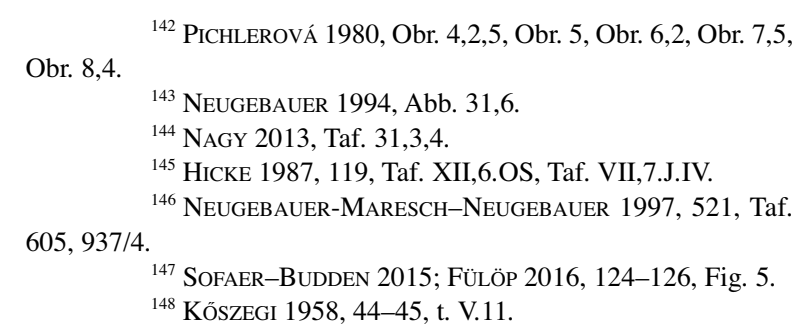

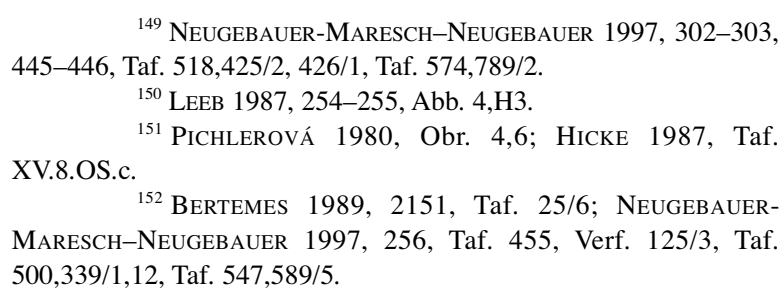

${ }^{149}$ Neugebauer-Maresch-Neugebauer 1997, 302-303, 445-446, Taf. 518,425/2, 426/1, Taf. 574,789/2.

${ }^{150}$ LeEB 1987, 254-255, Abb. 4,H3 XV.8.OS.c.

${ }^{151}$ Pichlerová 1980, Obr. 4,6; Hicke 1987, Taf.

${ }^{152}$ Bertemes 1989, 2151, Taf. 25/6; NeugebauerMaresch-Neugebauer 1997, 256, Taf. 455, Verf. 125/3, Taf. 500,339/1,12, Taf. 547,589/5. 
In graves 57 and 66, single handled bell shaped jars (Type Leeb H2) with slightly S-shaped profiles were found, in very fragmented state (Fig. 39.8-9). Because of this condition, it is unfortunately uncertain where the handles were attached. As for Gáta-Wieselburg finds from Austria it is more often that one finds the handle attached to the neck. ${ }^{153} \mathrm{~A}$ fragment of this type is known also from Bratislava-Rusovce. ${ }^{154}$

Pots with curved profiles (Types Leeb H1, J1, and Hicke T1), and with knobs, were found in graves 76 and 79 at Nagycenk (Fig. 39.19-20). In general, one often finds traces of handles on the neck of the pots with S-shaped profiles, and the 1987 classification system also emphasizes the role of knobs, seated on the neck of the pots - cf. Type J1. ${ }^{155}$ Pots from Nagycenk have their parallels in grave 17 at Bratislava-Rusovce. ${ }^{156}$ The one in grave 66 (find no. 6, Fig. 39.23), however, had a longer handle-knob and a slightly more articulated profile, the parallels of which are known from Zsennye and Szeleste. ${ }^{157}$

The pot in grave 75 (find no. 1) represents a different type, closer to Type H1 (Fig. 39.13). From Hungary there is one similar piece: a scatter find from Simaság. ${ }^{158}$ The widespread use of handled pots is well illustrated by the fact that another analogous vessel was found in the cemetery of the Unterwölbing culture in Pottenbrunn. ${ }^{159}$ At Nagycenk in grave 56, there was one pot with a curved shoulder and a sharp carination on its body, resembling the type found in Unterwölbing cemeteries. ${ }^{160}$ During the later period of the Corded Ware culture, similar pots appeared in Moravia. ${ }^{161}$

Bowls (Fig. 39.26-32) were found in the lowest numbers at Nagycenk: there were seven altogether, and almost every one of them was quite fragmented.

In grave 65, there was a large vessel placed at the heads of the two skeletons (find no. 1, Fig. 39.26). Based on its large depth, one may call it a bowl-pot. In context of other Gáta-Wieselburg cemeteries, this form type remains without any parallel. The closest parallels are, in fact, vessels from Százhalombatta-Földvár and CeglédÖreghegy, dating from the period of the Vatya culture. ${ }^{162}$ Similar bowl-pots were found also at the fortified Madrovce settlement in Nitriansky Hrádok (Kisvárad), in a feature (no. 325) cutting through earlier layers, and other examples are known from the Slovakian territories of the Northern Transdanubian Encrusted Pottery Culture. This may indicate that this form type was widespread during the first half of the Hungarian Middle Bronze Age. ${ }^{163}$

A similar deep bowl without knobs was found in Táp-Borbapuszta, a settlement of the Makó-Kosihy-Čaka culture, which could be perhaps the antecedent of this form. ${ }^{164}$ Smaller vessels - with similar profile and rougher surface - were found also in several graves in Franzhausen. ${ }^{165}$

An elaborate bowl with three handles was found in grave 1 (Fig. 39.27). Its form resembles that of the Type G3 bowls found in Gáta-Wieselburg cemeteries, yet, those bowls can be rather characterized by reverse truncated cone-shaped profiles. ${ }^{166}$ Vessels similar to the Nagycenk example, with curved profile and short handles, are known from the Gemeinlebarn cemetery of the Unterwölbing culture. ${ }^{167}$

Most bowls with articulated profiles are characterized by 2 or 3 parts divided by carinations. Although the form of the bowl in grave 51 resembles that of the Type G2 bowls, ${ }^{168}$ instead of handles, there were knobs with vertical holes attached to their shoulders (Fig. 39.28). Parallel finds are known from those sites, which chronologically follow earlier Bell Beaker sites, e.g. in grave 1 at Ragelsdorf in the Oggau-Ragelsdorf group. ${ }^{169} \mathrm{~A}$ bowl from the grave of the early Nagyrév culture in Szigetszentmiklós-Felső-Ürge-hegyi dülő had also two handles, in which vertical holes were drilled. ${ }^{170}$ Horizontal knobs with vertical holes occurred also in the period of the Corded Ware culture and of the Unterwölbing culture, e.g. in case of bowls found in the cemetery of Franzhausen I. ${ }^{171}$

In graves 62 and 78, there were bowls with everted rims and carinations at the bottom of the neck (Fig. 39.29.31). Clearly they are Gáta-Wieselburg G2 or SCH 2 bowl types, their handles, however, have not been well preserved. ${ }^{172}$ Parallel finds, with double handles, are known from grave 20 in the Bratislava-Rusovce cem-

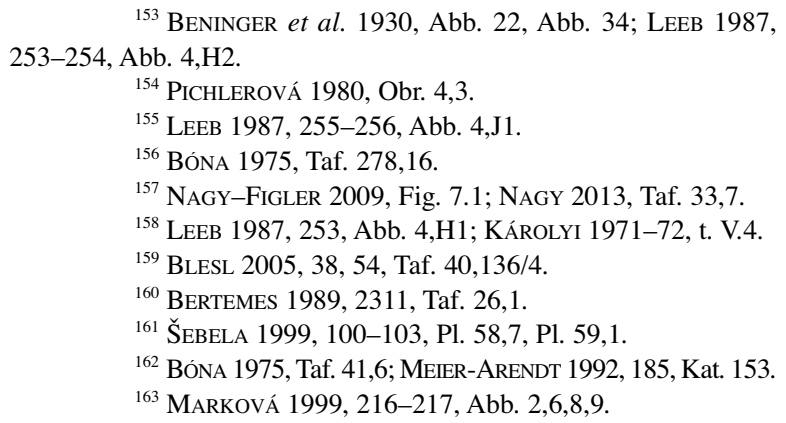

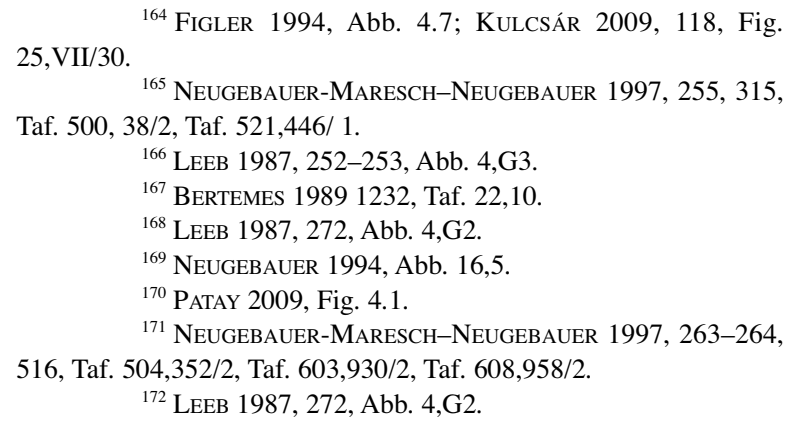


etery. ${ }^{173}$ In graves 53 (of a child) and 66 (Fig. 39.30.32) the bowls preserved only fragmentarily, but the fragments show a tripartite form, characteristic for Type G1, which can be dated to a later period. ${ }^{174}$ There is a similar vessel from Gattendorf, which was found as a scatter find, and there has been another one published, found in a burial at Hainburg. ${ }^{175}$

\section{Decorations of vessels}

The vessels were primarily ornamented with appliqué decorations. The small pots, of which a significant number was found, often had 1-3 oval knobs on their necks, or on their shoulders. The amphorae with short handles also often had small knobs - the sides of which were recessed, like fake-handles -, applied to the carinations on their belly. In case of three-handled amphorae, the sides opposite to the short handles were characteristically decorated with ribs. A fragment from grave 79 is decorated with a reverse U-shape rib (Fig. 24.79.2), while other finds from the graves were decorated with W-shaped patterns. Also, a rough made version of the same pattern appears on a vessel from grave 73 (Fig. 38.15). At Zsennye such vessels were decorated with cross-shaped ribs opposite the short handles attached to the body. At Gattendorf, from where the culture received its name, there are examples decorated with omega-shapes, while at the cemetery in Bratislava-Rusovce, vessels were decorated with uneven wavy lines. ${ }^{176}$ The question remains, whether such variations in the type of appliqué decorations reflect chronological differences, or are rather related to the function of the vessels (i.e. what they contained), or express something symbolic in connection to the deceased. ${ }^{177}$ The $\mathrm{W}$-shape was likely the less elaborately finished version of the swallowtail or anchor pattern, widespread in context of both the metal and ceramic finds of the Kisapostag and Transdanubian Encrusted Pottery Cultures. ${ }^{178}$

The profiles of single-handled cups, double-handled jugs and amphorae were often articulated by horizontal ribs running around the belly or the base of the neck. Find no. 3 in grave 79, and find no. 2/A were jugs, decorated with more complex patterns of ribs on the upper parts of their body (Fig. 38.5.7). Vertical ribs running down from the neck to the carination on the belly, is a pattern characteristic for one of the groups of the Corded Ware culture, in the lower region of the Traisen Valley. ${ }^{179}$ A vessel in Franzhausen has its exact parallels in Nové Zámky (Érsekújvár) (Makó-Kosihy-Čaka culture). ${ }^{180}$ The upper parts of jugs, found in the cemetery of Franzhausen I, dated to the period of the Corded Ware culture, were also decorated with ribs. ${ }^{181}$ As has been pointed out, ribs applied to the upper parts of vessels (primarily of larger ones) is a type of decoration in the Gáta-Wieselburg culture, which goes back to the traditions of the Corded Ware culture. ${ }^{182}$

Incised decorations - bands of lines running around the base of the neck, and below the base of the handles - were characteristic for single-handled cups, double-handled jugs and amphorae. The unevenly incised wavy lines on find no. 8 in grave 1 (Fig. 38.14) has a good parallel, found in a grave at Szakony. ${ }^{183}$ Bands of lines decorating the cup from grave 79, and an amphora (find no. 1) in grave 56 (Fig. 38.6.21) resemble the patterns composed of ribs found on some jugs (grave 27/ 2/A, grave 79/3, Fig. 38.5.7).

\section{Organic materials}

Apart from ceramic vessels (bowls, jugs, and pots), food could be placed also in wooden vessels or caskets. This can be inferred, for example, in case of grave 55, where a high status man was buried with rich grave goods (bronze dagger, spiral arm ring, neck ring, and four gold hair rings), and the grave-pit was quite large and deep. However, ceramic fragments could be collected only from the area around his head, despite that there was a 1 meter long empty space left at his feet. In grave 77 the girl with the bronze diadem had no ceramic vessels, and the large

${ }^{173}$ BÓNA 1975, Taf. 278,6.

${ }^{174}$ LEEB 1987, 272, Abb. 4,G1.

${ }^{175}$ BÓNA 1975, Taf. 274,6; Neugebauer 1994, Abb. 30,13.

176 BÓNA 1975, Taf. 274,14, Taf. 281,16; Pichlerová 1980, Obr. 4,1; NAGy 2013, 98-99, Taf. 26, Taf. 32.

${ }^{177}$ HAJDU et al. 2016, 362-365.

${ }^{178}$ KISs 2012, 101-103.

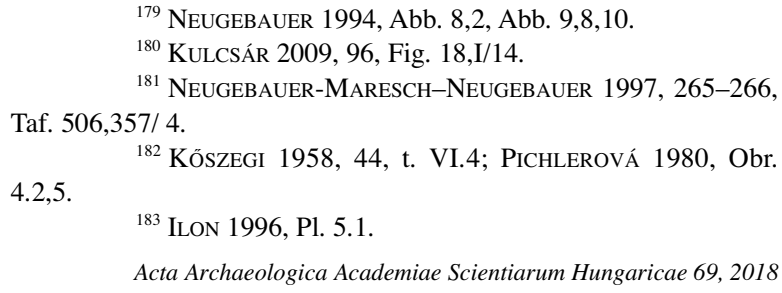

${ }^{179}$ Neugebauer 1994, Abb. 8,2, Abb. 9,8,10.

${ }^{180}$ KulCSÁR 2009, 96, Fig. 18,I/14.

${ }^{181}$ Neugebauer-Maresch-Neugebauer 1997, 265-266, Taf. 506,357/ 4 .

${ }^{182}$ Kőszegi 1958, 44, t. VI.4; Pichlerová 1980, Obr. 4.2,5.

${ }^{183}$ ILON 1996, Pl. 5.1.

Acta Archaeologica Academiae Scientiarum Hungaricae 69, 2018 
size of her grave again makes us think that perhaps food was placed in the grave pit in wood containers (e.g. wicker baskets). The hand gesture of this young woman could imply on holding an artifact, which is not preserved. ${ }^{184} \mathrm{As}$ an example we can refer to a roughly contemporaneous inhumation burial of the Maros culture at Hódmezővásárhely, where a decorated textile (dress) was reconstructed, based on the remained bronze and snail ornaments. ${ }^{185}$ At Nagycenk the conditions of the excavation and preservation did not allow us to observe textile remains. In the mentioned cemetery of Zsennye, however, there was a spiral arm ring in one of the graves, the corrosion of which preserved traces of a piece of textile, made from a mix of linen and hemp. A dyed flax veil or headkerchief is also known from the contemporary cemetery of the Unterwölbling culture at Franzhausen. ${ }^{186}$

On the skull of the woman in grave 73 there was a $1 \mathrm{~cm}$ wide band of brownish-blackish discoloration, as pointed out by Zs. Zoffmann. This was perhaps the trace of a leather band, holding the headpiece, or part of a cap. ${ }^{187}$ In the heavily disturbed Gáta-Wieselburg cemetery in Hegyeshalom, there were several female burials, in which blackish organic materials were found around the place of the skulls, yet, the skulls themselves were missing from the graves, so it could not be clarified whether these individuals had headgears. ${ }^{188}$ The spectacular female headgears found in the Franzhausen I cemetery, representing the Early Bronze Age material culture of Central Europe, were also decorations of textile or leather caps, or of veils. ${ }^{189}$

In grave 55, traces of the wooden handle of a flanged axe were observed on the right side of the skeleton. Traces of dagger handlers and coffins were also found in the graves (as described above). ${ }^{190}$

\section{THE RELATIVE AND ABSOLUTE CHRONOLOGY OF THE EXCAVATED CEMETERY SECTION}

Based on the style of ceramic vessels, the cemetery was opened in the early phase of the Gáta-Wieselburg culture, in Phase 3 of the Hungarian Early Bronze Age (R Br A1b). Later burials date from the early phase of the Middle Bronze Age ( $\mathrm{R} \mathrm{Br}$ A2a-b). When determining relative chronology, it is important to consider that certain elements of ceramic styles characteristic of Phase 2 of the Hungarian Early Bronze Age live on. For example, the forms of the Somogyvár-Vinkovci, and Corded Ware-type cups, the decorations typical for the Late Corded Ware culture, or the forms of Oggau-Ragelsdorf type bowls can be found, which go back to traditions of the Bell Beaker people. However, forms characteristic for the early Gáta-Wieselburg culture - e.g. Type C cups, less articulated double handled jugs are dominant in the Nagycenk assemblage. Apart from the amphorae found in graves 54 and 56, and in the ceramic depot (feature 27), the use of sharply articulated profiles was untypical - except for two bowls. Since there has been only a small number of Gáta-Wieselburg assemblages published, in addition to scatter finds, the chronologies of large cemeteries with multiple phases are yet to be worked out. Based on the vessels found at Nagycenk and their parallels, probable datings (either to the early or the late phase of the cemetery) could be suggested in case of some graves. Among the more prestigious burials, grave 1 dates likely from the earlier phase, based on the curved profile of the double-handled jug, and the slightly spherical shape of the bowl. In case of grave 55, the elaborate style of the jug with base ring suggests a later date, yet, the absolute dating of the grave - 2030-1940 calBC (68.2\%) - is the earliest among the published radiocarbon dates in context of this culture. The forms of cups from graves 73 and 74 may indicate that these graves belong to the early core of the cemetery. Grave 66 was situated in the same area, however, the one bowl found there, which had an articulated profile, is of rather late date, similarly to the biconical jug in grave 62 , the bowl in grave 53, and the amphorae - with sharp carinations - in graves 54 and 56 (female burials). This western part of the excavated area (including graves $53,54,56,61,62$ ) may represent the later phase of the cemetery, and this was confirmed by a relatively late radiocarbon date from grave 61: 1880-1770 calBC (68.2\%) (Fig. 41).

\footnotetext{
${ }^{184}$ Based on the position of the hands in grave 77 one may suggest that there was a harp-like stringed instrument or lyre - made of wood and other organic material. Although harps were found as early as 2600 BC, in Sumerian royal burials, if there had been such an instrument in the Nagycenk grave, the soil mark would have indicated that, similar to the wooden handle of the axe in grave 55 . ${ }^{185}$ V. SZABó 1997, 64-69.
}

${ }^{186}$ NAGY 2013, 115-116, Taf. 41-42; GRÖMER et al. 2016,

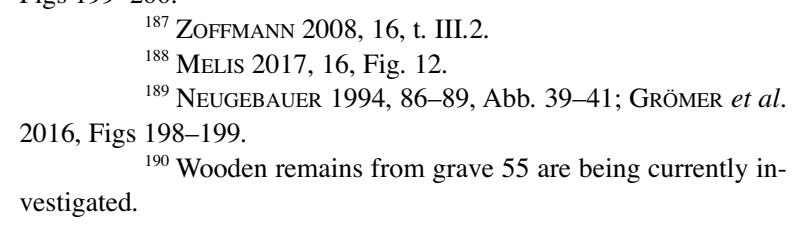




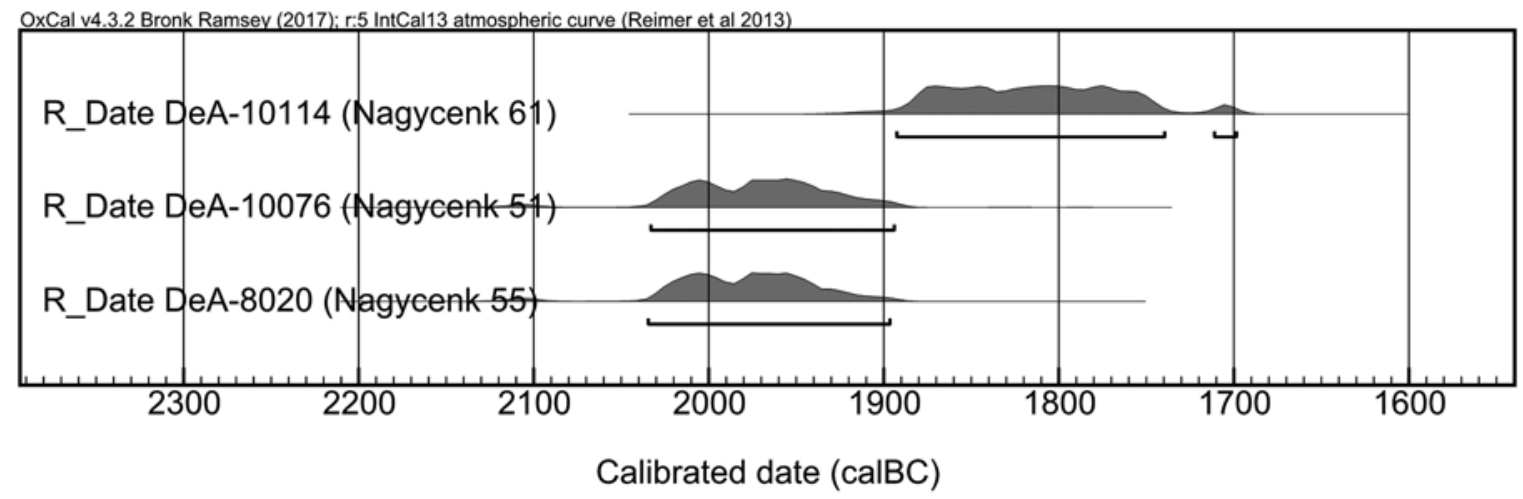

Fig. 41. Radiocarbon dates from at Nagycenk-Lapos-rét, graves 55, 51, 61 (calibrated with the program OxCal 4.3, and calibration curve IntCal 13; BRONK RAMSEY 2009; REIMER et al. 2013)

As for metal finds typical for Gáta-Wieselburg cemeteries later forms (e.g. pins with spherical heads, or with twisted stems) ${ }^{191}$ did not occur at Nagycenk. Among the youngest artefacts, there is a pin with rolled head (Rollenkopfnadel). Based on material composition analysis, bronze objects from graves 55, 62, 76, 77 (the daggers, arm rings, hair rings, as well as the axe and the diadem) also suggest later dating, while the copper objects in grave 1 belong to the earlier phase.

\section{SOCIAL ORGANIZATION AS REFLECTED BY THE EXCAVATED PART OF THE CEMETERY}

The Nagycenk cemetery is relatively richer than other Gáta-Wieselburg burial sites with its 30 copper and bronze and 5 gold artefacts: in Hegyeshalom, there were 42 bronze objects found in 58 graves, which is only a little higher number than in the excavated 27 burials of Nagycenk, and status symbolizing objects were not well represented (there were only one neck ring and one dagger found, and there was no diadem or axe). ${ }^{192}$ On the one hand, this could be perhaps explained by "grave robbings", i.e. the re-opening of graves, as this was typical for inhumation cemeteries of the Central European Early Bronze Age. ${ }^{193}$ Notably, none of the graves at Nagycenk was re-opened intentionally. On the other hand, the rich metal finds in both female and male burials, and occasionally in graves of children (e.g. grave 53) indicate the presence of high status families, where the wealth and status could be passed on the descendants. ${ }^{194}$ The social status of the 29 individuals was different and based on the grave inventories one may set up the following categories (Fig. 42-43). ${ }^{195}$

Category 1 a: Grave 55, where there was a man found, buried with a bronze dagger, an axe, an arm band, and four gold hair rings, as well as Grave 53, a child, ornated with a gold Noppenring, bronze hair rings and neck ring, a spiral bead, a bronze and Dentalium necklace and an armring, belong here too. The middle-aged warrior in grave 55 can be identified as a chief of the village community. His wealth is demonstrated not only by his weapons, but also by his gold hair rings. Similar gold hair rings and a flat bronze axe were found in burial assemblages of the Únětice culture in Central Germany, such as e.g. in the Fürstengrab at Osmünde (Saalkreis), dated to 1950-1650 BC. Compared to these large barrows, the Nagycenk grave (55) was certainly more modest, within the context of Gáta-Wieselburg culture cemeteries and the Nagycenk cemetery itself, however, this grave stands out clearly also with its larger size, so we can assume that this was the final resting place of a Bronze Age chief. The childe

${ }^{191}$ Neugebauer 1994, Abb. 28-29; Duberow et al. 2009, 338-340. Younger phase of the Gáta-Wieselburg culture can be dated between 1900 and $1600 \mathrm{BC}$, based on the four ${ }^{14} \mathrm{C}$ dates from the cemetery of Zsennye, spanning the entire Reinecke Br A2 period and the Hungarian Middle Bronze Age 1-2 phases. NAGY 2013, Abb. 3-6; MELIS 2017, Table 1.

${ }^{192}$ MeLis in print, $a$.
${ }^{193}$ KÜMMEL 2009, 170-173; KRENN-LeEB 2011a, 18-25; BenKovsky-PIVOVAROVÁ-CHROPOVSKÝ 2015, 96-97, Abb. 104; Melis 2017.

${ }^{194}$ SOSNA 2009, 131-132; KISS 2012, 254.

${ }^{195}$ SchWARZ 2014, 718-719, Abb. 1A-1B; MelLer 2017. The grave inventory of the small child and the woman's grave finds in grave 66 could not be separated. 


\section{1}

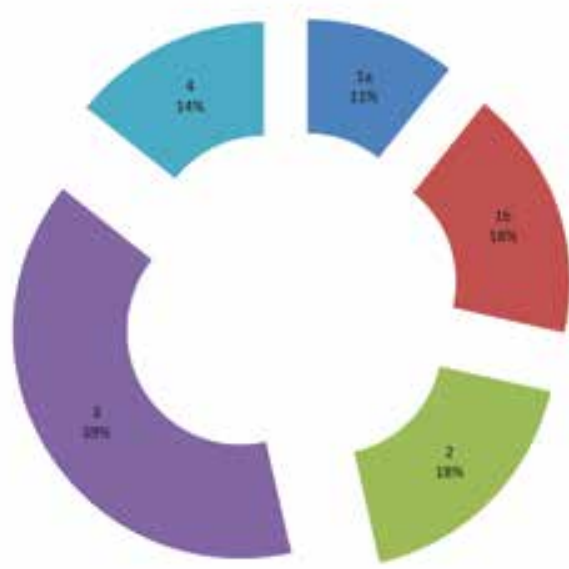

2

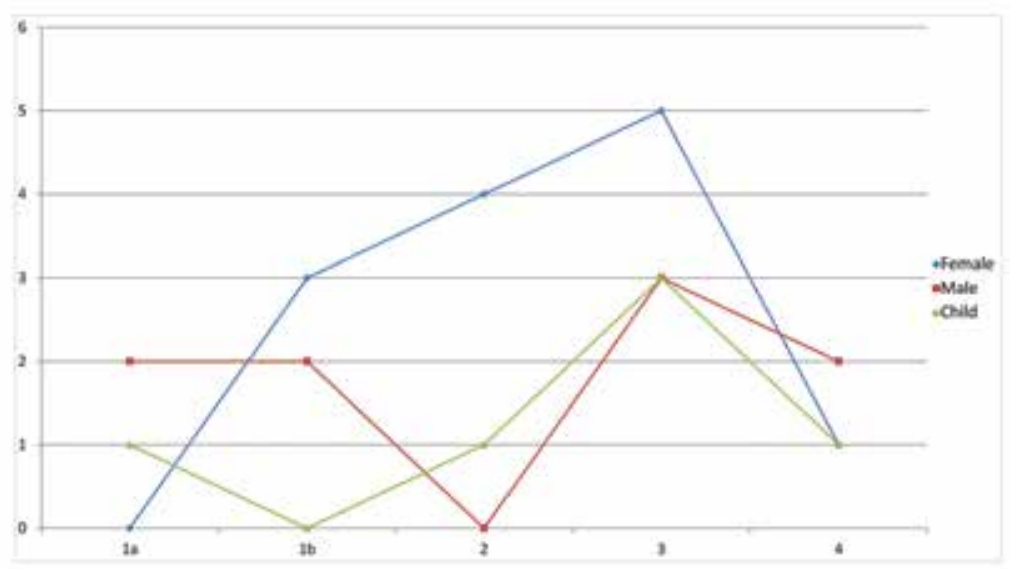

Fig. 42. 1: Distribution of social categories at Nagycenk-Lapos-rét based on grave goods; 2: Association of social categories with sex and age

(in grave 53) with a gold hair ring and copper neck ring was perhaps a member of this high status family, too. Grave 1 - with the wooden structure - also belongs here, in which a young man was laid, buried with multiple metal ${ }^{196}$ artefacts (two copper neck rings, two copper daggers, an arm ring, and a Cypriot pin).

Category $1 \mathrm{~b}$ consist of both male (graves 61, 62) and female burials (graves 54, 77, and perhaps 79). These individuals were of somewhat lesser status, buried with heavy copper or bronze objects, daggers, jewelries (neck rings, diadem, arm ring), but no gold jewelries. The young girl with the bronze diadem (grave 77) buried nearby were perhaps another member of the mentioned high status family.

Category 2 consists of graves $56,58,66,76,78$, where we find individuals buried only with small pieces of bronze jewelry (e.g. hair rings, bronze spirals).

Category 3 includes individuals, who were buried only with vessels in graves 51,57,65/B males, females in graves 64, 65/A, 68, 73, 74; children in graves 57, 59, 70 .

Category 4 consists of four graves without grave goods: graves 60, 69 (of men); 67 (a woman), and 71 (a child).

Based on the recently published analysis of 23 burials in the cemetery at Zsennye, there were similarly four hierarchical categories established by M. Nagy, from the lowest (I.) to the highest (IV.). ${ }^{197}$ There was only grave 15 in the highest category (IV), of a man, who was buried with two neck rings and gold hair rings. Burials categorized

196 The deposition of several, almost identical weapons 


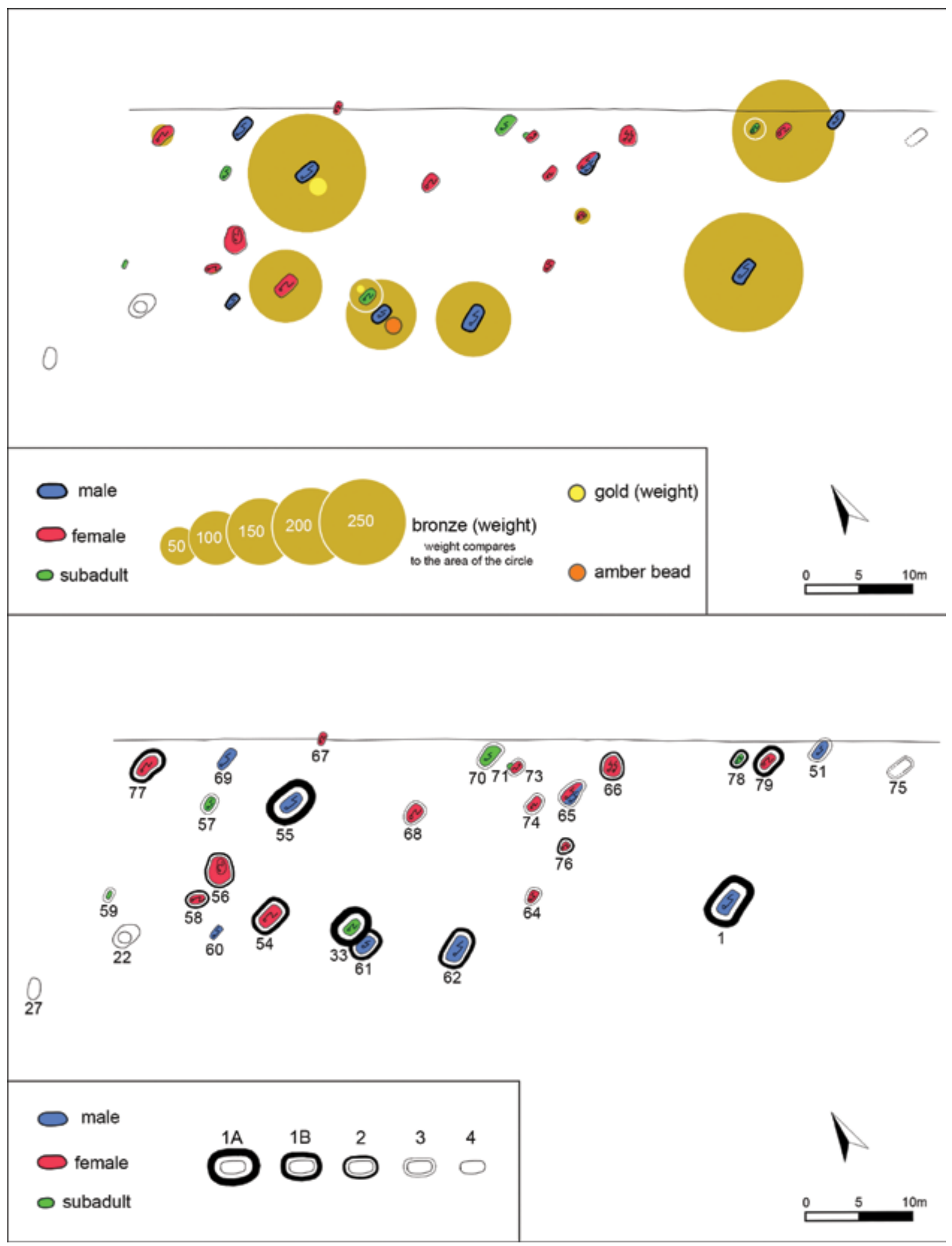

Fig. 43. 1: Map of Nagycenk-Lapos-rét cemetery with weight of the metal grave goods; 2: Map of Nagycenk-Lapos-rét cemetery with social categories based on grave assemblages 
as Category III at Zsennye, were the ones with bronze objects, i.e. individuals, who were buried with possible status symbols (one with a fragmented neck ring, the other with a dagger: graves 1 and 13). There were 9 burials in the (II) category, buried only with ceramic vessels, and another 9 in the lowest category (I) without grave goods. These data provide a picture on a social hierarchy similar to that in Nagycenk, however, in Zsennye the burials were heavily disturbed, and the proportion of deceased, buried only with ceramic or without grave goods, is much higher. The similar model of the social organization of the contemporary Únětice culture was established recently by $\mathrm{H}$. Meller, based on an analysis of grave inventories. ${ }^{198}$ According to this model the biruals from Nagycentk correspond to the lower five tiers of the Únětice culture's social pyramid.

The oval arrangement of burials around grave 55 and grave 1 suggests that each of these correspond to a household of high status men representing a few generations of people living in the settlement excavated close to the cemetery of Nagycenk.

\section{SUMMARY}

The 29 individuals found in 27 graves at Nagycenk were buried there in the time period between 2000$1700 \mathrm{BC}$, according to radiocarbon dates - i.e. at the end of the Early Bronze Age and the beginning of the Middle Bronze Age in Hungary. The cemetery is of unique importance, both because of the richness of the assemblages ( 30 bronze objects, 5 gold jewelries) and the scarcity of published Gáta-Wieselburg cemeteries. 15 percent of the ca. 180 burials in total, which relate to this culture in Hungary, are in this cemetery. Pottery style, typology and raw material of metal artefacts, as well as the absolute chronological data (with the earliest among the published radiocarbon dates in context of this culture) support the dating of the cemetery section to the early phase of the GátaWieselburg culture.

The 29 individuals were of different social status: based on their grave goods three of them were of the highest status (1a), and another five of them were of the second highest category (1b), buried with heavy bronze jewelries and weapons as status symbols. High status of the deceased ranked to category $1 \mathrm{a}-\mathrm{b}$, who may be equipped with a considerable amount of organic grave goods, is also suggested by the size and deepness of their grave pits. Five individuals were classified into a somewhat lower status category (with small bronze jewelries), 11 in the next one, only with ceramics, and four deceased without grave goods in the lowest category. Based on the excavated part of the cemetery few generations of the one or two high status households of the Bronze Age community at Nagycenk could have been studied.

\section{ACKNOWLEDGEMENTS}

Rescue excavations at Nagycenk were funded by the Györ-Sopron-Ebenfurt Railway Ltd. The evaluation and publication of the cemetery finds was financially supported by the Momentum Grant of the Hungarian Academy of Sciences. The conservation of the metal finds and of the amber bead found in the cemetery was carried out by Zsuzsa Heiserné. The conservation of burial vessels has been done by Veronika Harasztovics (Museum of Sopron) and Ágnes Hunyadi (Institute of Archaeology, Research Centre for the Humanities, Hungarian Academy of Sciences). Photographic documentation of the ceramic finds was done by Zoltán Bolodár (Museum of Sopron) and Péter Hámori (Institute of Achaeology, Research Centre for the Humanities, Hungarian Academy of Sciences). Evaluation and drawing of the chipped stone tools were made by Anna Priskin. The anthropological assessment was carried out by Zsuzsanna K. Zoffmann; the paleopathological analysis was done by Kitti Köhler. The material composition analysis of metal finds was conducted by Boglárka Maróti (Budapest Neutron Centre) and Ernst Pernicka (Curt-Engelhorn-Zentrums Archäometrie). The petrographic examination of ceramic finds was carried out by Attila Kreiter and Péter Skoda (Hungarian National Museum, Laboratory for Applied Research). Krisztina Balassa and Mihály Göbölyös (Museum of Sopron) took part in the excavations as archaeological technicians, responsible to help producing grave plans, drawing archaeological finds, digitizing the field records, and cataloguing

${ }^{198}$ SchWARZ 2014, 718-719, Abb. 1A-1B; MELLER 2017.

Acta Archaeologica Academiae Scientiarum Hungaricae 69, 2018 
the finds. Hereby, the authors thank for their contribution. The finds of the Bronze Age cemetery are curated by the Museum of Sopron (Inv. No. 2006.1.1.1-2006.1.79.1). We owe a special thank to László Gucsi, for his useful observations, drawing of the finds and editing the figures for this publication.

\section{REFERENCES}

AsPÖCK 2008

AsPÖCK 2013

ASPÖCK 2015

ASPÖCK-BANERJEA 2016

BARTíK et al. 2016

BAZOVSKÝ-ŠEFČÁKOVÁ 1999

BÁTORA 2000

BÁTORA 2009

BENINGER et al. 1930

BENKOVSKY-PIVOVAROVÁCHROPOVSKÝ 2015

BERTEMES 1989

BLESL 2005

BÓNA 1960

BÓNA 1975

BRONK RAMSEY 2009

BUTLER 1978

DANI et al. 2003

DANI-V. SZABÓ 2004
= E. AsPÖCK: What actually is a deviant burial? Comparing German-language and anglophone research. In: Deviant Burial in the Archaeological Record. Ed.: E. M. Murhy. Studies in funerary archaeology 2. Oxford 2008, 17-34.

= E. AsPöcK: Über die Variabilität von Totenpraktiken. Oder: Probleme einer dichotomen Auffassung von Toten- bzw. Bestattungsbrauchtum. In: „Irreguläre“ Bestattungen in der Urgeschichte: Norm, Ritual, Strafe ...? Akten der Internationalen Tagung in Frankfurt a. M. vom 3. bis 5. Februar 2012. Hrsg.: N. Müller-Scheeßel. Kolloquien zur Vor- und Frühgeschichte 19. Bonn 2013, 25-38.

= E. AsPÖCK: Cross-cultural interpretations and archaeological context. A reopened Early Bronze Age grave in Weiden am See, Austria. In: Kończyny, kości i wtórnie otwarte groby w dawnych kulturach - Limbs, Bones, and Reopened Graves in Past Societies. International Interdisciplinary Meetings: Motifs Through The Ages. 2. Red.: L. Gardeła, K. Kajkowski. Bytów 2015, 22-43.

= E. ASPÖCK - R. BANERJEA: Formation processes of a reopened early Bronze Age inhumation grave in Austria: The soil thin section analyses. Journal of Archaeological Science: Reports 2016, http:// dx.doi.org/10.1016/j.jasrep.2016.07.003. 1-19.

= J. BARTÍK-I. BAZOVSKÝ-P. JELÍNEK-A. ŠEFČÁKOVÁ: Osídlenie Bratislavy-Rusoviec v staršej dobe bronzovej (Besiedlung von Bratislava-Rusovce während der älteren Bronzezeit). In: Zborník na Pamiatku Magdy Pichlerovej. Red.: I. Bazovský. ZbSNM - Archeológia Supplementum 11. Štúdie. Bratislava 2016, 45-74.

= I. BAZOVSKÝ-A. ŠEFČÁKOVÁ: Die neuesten Grabfunde der Wieselburger kultur in Bratislava-Rusovce. In: Aktuelle Probleme der Erforschung der Frühbronzezeit in Böhmen und Mähren und in der Slowakei. Hrsg.: J. Bátora, J. Peška. Archaeologica Slovaca monographiae - Communicationes 1. Nitra 1999, 53-61.

= J. BÁTORA: Das Gräberfeld von Jelšovce/Slowakei: Ein Beitrag zur Frühbronzezeit im nordwestlichen Karpatenbecken. Prähistorische Archäologie in Südosteuropa 16. Kiel 2000.

= J. BÁTORA: Hroby s dýkami na pohrebisku zo staršej doby bronzovej v Ludaniciach-Mýtnej Novej Vsi (Gräber mit Dolchen auf dem frühbronzezeitlichen Gräberfeld in Ludanice-Mýtna Nová Ves). S1A 57 (2009) 221-260.

= E. BENINGER-F. MÜHLHOFER-E. GEYER: Das frühbronzezeitliche Reihengräberfeld bei HainburgTeichtal. MAGW 60 (1930) 65-140.

$=$ Z. Benkovsky-Pivovarová-B. CHROPOvskÝ: Grabfunde der frühen und der beginnenden mittleren Bronzezeit in der Westslowakei. 2. Archaeologica Slovaca monographiae 22. Nitra 2015.

= F. BERTEMES: Das frühbronzezeitliche Gräberfeld von Gemeinlebarn. Kulturhistorische und paläometallurgische Studien. Saarbrücker Beiträge zum Altertumskunde 45. Bonn 1989.

= C. BLESL: Das frühbronzezeitliche Gräberfeld von Pottenbrunn. FÖ Materialhefte A/15. St. Pölten 2005.

= I. BÓNA: Az oroszvári 4. női sír melldísze (Adatok a közép-dunamedencei bronzkori viselethez II.) (The pectoral ornament of the female grave 4 at Oroszvár. Data illustrating the costume of the Bronze Age in the Middle Danube Basin. II.). ArchÉrt 87 (1960) 198-203.

= I. BóNA: Die mittlere Bronzezeit Ungarns und ihre südöstlichen Beziehungen. ArchHung 49. Budapest 1975.

= C. BRONK RAMSEY: Bayesian analysis of radiocarbon dates. Radiocarbon 5 (2009) 337-360.

= J. J. ButleR: Rings and Ribs: The Copper Types of the »Ingot Hoards « of the Central European Early Bronze Age. In: The Origins of Metallurgy in Atlantic Europe. Proceedings of the Fifth Atlantic Colloquium Dublin. Ed.: M. Ryan. Dublin 1978, 345-362.

= J. DANI-M. Sz. MÁthÉ-G. V. Szabó: Ausgrabungen in der bronzezeitlichen Tell-Siedlung und im Gräberfeld von Polgár-Kenderföld (Vorbericht über die Freilegung des mittelbronzezeitlichen Gräberfeldes von Polgárkenderföld, Majoros-tanya). In: Bronzezeitliche Kulturerscheinungen im karpatischen Raum. Die Beziehung zu den benachbarten Gebieten. Ehrensymposium für Alexandru Vulpe zum 70. Geburtstag. Baia Mare, 10. -13. Oktober 2001. Ed.: C. Kacsó. Bibliotheca Marmatia 2. Baia Mare 2003, 93-118.

= J. DANI-G. V. SzABó: Temetkezési szokások a Polgár határában feltárt középső bronzkori temetőkben (Bestattungsgebräuche in der Friedhöfen aus der mittleren Bronzezeit freigelegt in der Feldmark 
DUBEROW et al. 2009

EGG-SPINDLER 2009

EHRGARTNER 1959

ERNÉE 2015

Field Guide 2005

FIGLER 1994

FIGLER 1996

FISCHL et al. 1999

FISCHL et al. 2013

FISCHL et al. 2015

FITZPATRICK 2011

FRANZ et al. 2014

FÜLÖP 2016

GÖMÖRI 2007

GÖMÖRI 2011

GÖMÖRI 2012

GÖMÖRI 2016

GRÖMER 2016

HAJDU et al. 2016

HANSEN 2002

HICKE 1987 von Polgár). In: M MO $\Sigma$ III. Halottkultusz és temetkezés. Öskoros kutatók III. összejövetelének konferenciakötete, Szombathely-Bozsok 2002. okt. 7-9. Ed.: G. Ilon. Szombathely 2004, 91-119. = E. Duberow-E. PernicKA-A. Krenn-Leeb: Eastern Alps or Western Carpathians: Early Bronze Age. Metal within the Wieselburg Culture. Eastern Alps or Western Carpathians: Early Bronze Age within the Wieselburg culture. In: Metals and Societies. Studies in honour of Barbara S. Ottaway. Eds: T. L. Kienlin-B. Roberts. UPA 169. Bonn 2009, 336-349.

= M. EGG-K. SpINDLER: Kleidung und Ausrüstung der Gletschermumie aus den Ötztaler Alpen. Monographien Razm 77. Mainz 2009.

= W. Ehrgartner: Die Schädel aus den frühbronzezeitlichen Gräbern von Hainburg, Niederösterreich. MAGW 88-89 (1959) 8-91.

= M. ERNÉE: Prag-Miškovice. Archäologische und naturwissenschaftliche Untersuchungen zu Grabbau, Bestattungssitten und Inventaren einer frühbronzezeitlichen Nekropole. RGF 72. Darmstadt 2015.

$=$ Field Guide to the Excavation of Inhumated Human Remains. BAJR Practical Guide Series OSSAFreelance. Guide 14. Dunbar 2005. http://www.bajr.org/BAJRGuides/14.\%20Field\%20 Guide $\% 20$ to $\% 20$ the $\% 20$ Excavation $\% 20$ of\%20Human\%20Inhumated\%20Remains/FieldGuidetotheExcavationofHumanInhumatedRemains.pdf [2018.03.23.]

= A. FIGLER: Die Fragen der Frühbronzezeit in Nordwest-Transdanubien. ZalaiMúz 5 (1994) 21-37.

= A. FIGLER: Adatok Győr környékének bronzkorához. Bronzkori kultúrák Győr környékén (Angaben zur Bronzezeit in der Umgebung von Győr. Bronzezeitliche Kulturen in der Umgebung von Győr) PápaMÉ 6 (1996) 7-29.

= K. P. FISCHL-V. KISS-G. KulCSÁR: Kora és középső bronzkori település Baks-Homokbánya (Csongrád megye) lelőhelyen (Früh- und mittelbronzezeitliche Siedlungen auf dem Fundort Baks-Homokbánya, Komitat Csongrád). MFMÉ-StudArch 5 (1999) 77-190.

= K. P. FISCHL-V. KISS-G. KULCSÁR-V. SZEVERÉNYI: Transformations in the Carpathian Basin around 1600 B. C. In: 1600 - Cultural Change in the Shadow of the Thera-Eruption? Eds: H. Meller, F. Bertemes, H-R. Borkund, R. Risch. Tagungen des Landesmuseums für Vorgeschichte Halle 9. Halle (Saale) 2013, 355-372.

= K. P. FISCHL-V. KISS-G. KULCSÁR-V. SZEVERÉNYI: Old and new narratives for the Carpathian Basin around 2200 BC. In: 2200 BC - A Climatic Breakdown as a Cause for the Collapse of the Old World? Eds: H. Meller, W. H. Arz, R. Jung, R. Risch. 7th Archaeological Conference of Central Germany. October 23-26, 2014 in Halle (Saale). Tagungen des Landesmuseums für Vorgeschichte Halle 12. Halle (Saale) 2015, 503-524.

= A. P. FitzPATRICK: The Amesbury Archer and the Boscombe Bowmen. Bell Beaker Burials at Boscombe Down, Amesbury, Wiltshire. Wessex archaeology report 27. Salisbury, 2011.

= N. FranZ-J. SchwarZäUgl-A. TögEL-W. TögEL: KG Weiden am See, MG Weiden am See. FÖ 53 (2014) 173-174.

= K. FÜLÖP: Különleges késő bronzkori gyermeksír és miniatür edénykészlete (A special Late Bronze Age child grave and its miniature vessel set). Tisicum 25 (2016) 121-132.

= J. GöMÖRI: Nagycenk, Köves-rét dűlő (Győr-Moson-Sopron megye). In: Százszorszépek. Emberábrázolás az őskori Nyugat-Magyarországon. Kiállítási katalógus (Wonderful Beauties. Human Representations in Prehistoric Western Hungary). Ed.: G. Ilon. Szombathely 2007, 114-117.

= J: GÖMÖRI: A nagycenki idolpár lelőkörülményei (Die Fundumstände des neolithischen Idolpaares von Nagycenk). In: „,..eleitől fogva”. A 75 éves Makkay János köszöntése. Eds: M. Fekete, A. Vitári Wéber. SpecN Supplementum 11. Vivarium fontium 6. Pécs 2011, 75-94.

= J. GöMÖRI: Fertő-Hanság Nemzeti Park, a Fertő D-i partszakaszának régészeti lelőhelyei (2012-ig) (Archäologische Fundstellen am Südufer der Neusiedler Sees, bis 2012). In: Fertő-Hanság - Neusiedler See-Seewinkel. Nemzeti Park - Monografikus tanulmányok a Fertő és a Hanság vidékéről. Eds: L. Kárpáti, J. Fally. Fertő-Hanság Nemzeti Park Igazgatóság, Budapest 2012, 258-270.

= J. GöMÖRI: Árpád-kori település Nagycenk határárában - Előzetes jelentés (Settlement from the Árpád Age in the victinity of Nagycenk). In: Beatus homo qui invenit sapientiam. Ünnepi kötet Tomka Péter 75. születésnapjára. Eds: T. Csécs, M. Takács. Győr 2016, 229-244.

= K. GRÖMER: The Art of Prehistoric Textile Making. The development of craft traditions and clothing in Central Europe. Wien 2016.

$=$ T. HAJdU-A. GYÖRGY-ToronYI-I. PAP-W. RosEndAHL-G. SZABÓ: The chronology and meaning of the Transdanubian encrusted pottery decoration. PZ 91 (2016) 353-368.

$=$ H. HANSEN: "Überausstattungen" in Gräbern und Horten der Frühbronzezeit. In: Vom Endneolithikum zur Frühbronzezeit: Muster sozialen Wandels? Tagung Bamberg14.-16. Juni 2001. Ed.: J. Müller. Bonn 2002, 151-173.

= W. HicKE: Hügel- und Flachgräber der Frühbronzezeit aus Jois und Oggau. Wissenschaftliche Arbeiten aus dem Burgenland 75. Eisenstadt 1987, 5-229. 
HORVÁTH-WILD 2017

ILON 1996

ILON 1999

ILON 2012

KALICZ-SCHREIBER 1991

KaLla et al. 2013

KÁROLYI 1971-72

KaUs 1993-94

KeMENCZEI 1988

KISS 2012

KNOLL-MELLER 2016

KovÁCS 1973

KovÁCs 1994

KŐSZEGI 1958

KRENN-LeEb 2010

KRENN-LEEB 2011a

KRENN-LEEB 2011b

KRENN-LeEB 2014

KRENN-LEEB-NEUGEBAUER 1999

KULCSÁR 2009

KULCSÁR-KISS 2016
= T. HorVÁth-E. M. WILD: Szombathely, 89. számú elkerülő út, 5. lelöhelyen (Reiszig-erdő alatti dülő) előkerült Boleráz és Kostolác kultúrák jelenségei és leletei.

A késő rézkor időszaka Szombathely városának területén és környékén [Finds and features of the Boleráz and Kostolác cultures at Road M89, Site 5, Reiszig-erdő alatti dülő. The Late Copper Age of the territory of Szombathely and its broader area]. Savaria 39 (2017) 103-148.

= G. ILON: Régészeti adatok Csepreg és vidéke őstörténetéhez [Archaeological data regarding prehistory of Csepreg and its region]. In: Tanulmányok Csepreg történetéből. Ed.: J. Dénes. Csepreg 1996, $6-43$.

= G. ILON: A bronzkori halomsíros kultúra temetkezései Nagydém-Középrépáspusztán és a hegykői edénydepot (Die Bestattungen der bronzezeitlichen Hügelgräberkultur in Nagydém-Középrépáspuszta und das Gefässdepot von Hegykő). Savaria 24/3 (1999) 239-276

= G. ILON: A halomsíros kultúra rituális „edénydepója” Veszprém határából (The ritual „,vessel hoard” of the Tumulus culture in the vicinity of Veszprém). In: Régészeti kutatások Magyarországon 2010. Ed.: J. Kisfaludi. Budapest 2012, 19-53.

= R. KALICZ-SCHREIBER: A Somogyvár-Vinkovci kultúra dél-északi irányú közvetítő szerepe a korabronzkorban (Die Vermittlungsrolle in Süd-Nord Richtung der Somogyvár-Vinkovci-Kultur in der Bronzezeit). BudRég 28 (1991) 9-43.

= G. KALlA-P. RACZKY-G. V. Szabó: Ünnep és lakoma a régészetben és az írásos forrásokban. Az őskori Európa és Mezopotámia példái alapján [Feast and feasting in the archaeological and written sources. Based on case studies from the prehistory of Europe and Mesopotamia]. In: Convivium Az Eötvös Loránd Tudományegyetem Bölcsészettudományi Karán 2012. november 6-7-én tartott vallástudományi konferencia előadásai \& Gaál Balázs Vegetarianizmus és nem-ártás az ókori Indiában-Keleti és nyugati perspektívák. Ed.: B. Déri. AГION könyvek 2. Budapest 2013, 11-46.

= M. KÁROLYI: Adatok a Nyugat-Dunántúl kora- és középső bronzkori történetéhez (Beiträge zur Geschichte der Früh- und Mittlerbronzezeit von Westtransdanubien). Savaria 5-6 (1971-1972) 167-194.

= M. KAUS: Ein mittelbronzezeitliches Hügelgrab mit Čaka-Nachbestattung von Neusedl-Hutweide, Bgld. MAGW 123-124, (1993-94) 89-104.

= T. KeMENCZEI: Die Schwerter in Ungarn. PBF IV/6. München 1988.

= V. KISS: Middle Bronze Age Encrusted Pottery in Western Hungary. VAH 27. Budapest 2012.

= F. KNOLL-H. MelleR: Die Ösenkopfnadel - Ein “Klassen"-verbindendes Trachtelement der Aunjetitzer Kultur. Ein Beitrag zu Kontext, Interpretation und Typochronologie der mitteldeutschen Exemplare. In: Arm und Reich - Zur Ressourcenverteilung in prähistorischen Gesellschaften: 8. Mitteldeutscher Archäologentag vom 22. bis 24. Oktober 2015 in Halle. Hrsg.: H. Meller, H. P. Hahn, R. Jung, R. Risch. Tagungen des Landesmuseums für Vorgeschichte Halle 14/ II. Halle/Saale 2016, 283-369.

= T. KovÁcs: Korai markolatlapos bronz tőrök a Kárpát-medencében (Frühe Bronzedolche mit Griffplatte im Karpatenbecken). ArchÉrt 100 (1973) 157-166.

= T. KovÁcs: Újabb adatok a mészbetétes kerámia kultúrájának fémmüvességéhez (Neuere Beiträge zur Metallkunst der Kultur der inkrustierten Keramik). VMMK 28 (1994) 119-132.

= F. KőszEgI: Az oroszvári bronzkori temető (The Bronze Age cemetery at Oroszvár [Rusovce]. FolArch 10 (1958) 43-59.

= A. KRENN-LeEb: Ressource versus Ritual - Deponierungsstrategien der Frühbronzezeit in Österreich. In: Der Griff nach den Sternen. Internationales Symposium in Halle (Saale) 16.-21. Februar 2005. Hrsg.: H. Meller, F. Bertemes. Tagungen des Landesmuseums für Vorgeschichte Halle 5. Halle/Saale 2010, 281-315.

= A. Krenn-LeEB: Zwischen Buckliger Welt und Kleinen Karpaten - Die Lebenswelt der WieselburgKultur. ArchÖ 22 (2011) 11-26.

= A. KrenN-LeEB: Grenzräume im Spannungsfeld Identität, Mobilität und Kommunikation: Frühbronzezeitliche Identitätengemeinschaften im mittleren Donauraum. In: Grenzen und Grenzräume? Beispiele aus Neolithikum und Bronzezeit. Fokus Jungsteinzeit. Hrsg.: T. Doppler, B. Ramminger, D. Schimmelpfennig. Berichte der AG Neolithikum 2. Kerpen-Loogh 2011, 257-276.

= A. KRENN-LEEB: Tabuisierung - Inszenierung - Transformierung. Bemerkungen zum Phänomen deponierter Gefäßensembles im Ritualkontext. ArchÖ 25 (2014) 25-31.

= A. Krenn-Leeb-J.-W. Neugebauer: Depotfunde der Bronzezeit im mittleren Donauraum. Vorwort der Herausgeber. In: Depotfunde der Bronzezeit im mittleren Donauraum. Hrsg.: A. Krenn-Leeb, J.-W. Neugebauer. Archäologie Österreichs Sonderausgabe 9/10 (1998/99) 4.

= G. KulcsÁR: The Beginnings of the Bronze Age in the Carpathian Basin. The Makó-Kosihy-Čaka and the Somogyvár-Vinkovci cultures in Hungary. VAH 23. Budapest 2009.

= G. KULCSÁR-V. KISS: Újra a balatonakali bronzkori sírról (The Bronze Age burial from Balatonakali - revisited). Tisicum 25 (2016) 73-80. 
KÜMMEL 2009

LAUERMANN 1995

LAUERMANN 2003

LEEB 1987

LEEB 1994

LENERZ DE WILDE 1995

MaLi 2014

MARKOVÁ 1999

MAYER 1977

MEIER-ARENDT 1992

MELLER 2014

MELLER 2017

MELIS 2013

MELIS 2017

MELIS in print, a

MeLIS in print, $b$

MELIS in print, $c$

MELIS in print, $d$

Mozsolics 1967

NAGY 2013

NAGY-FIGLER 2009
= C. KÜMMEL: Ur- und frühgeschitlicher Grabraub. Archäologische Interpretation und kulturanthropologische Erklärung. Tübinger Schriften zur Ur- und Frühgeschitlichen Archäologie 9. MünsterNew York-München 2009.

= E. LAUERMANN: Ein frühbronzezeitliches Gräberfeld aus Unterhautzenthal, NÖ. 1.: Archäologie. Österreichische Gesellschaft Ur- u Frühgeschichte Sektion Stockerau. Stockerau 1995.

= E. LAUERMANN: Studien zur Aunjetitz-Kultur im nördlichen Niederösterreich 1-2. UPA 99. Bonn 2003.

= A. LEEB: Überblick über die Chorologie, Typologie und Chronologie der Wieselburgerkultur. 100 Jahre Forschungsstand. In: HICKE 1987, 231-283.

= A. LEEB: Das frühbronzezeitliche Graberfeld von Melk/Spielberg-Flur Pielamünd, Niederösterreich (A Melk/Spielberg-Pielamünd-dülői korabronzkori temető [Alsó-Ausztria]). ZalaiMúz 5 (1994) 113-130.

= M. LENERZ DE WILDE: Prämonetäre Zahlungsmittel in der Kupfer- und Bronzezeit Mitteleuropas. FBBW 20 (1995) 229-327.

= P. MALI: Biatorbágy-Szarvasugrás középső bronzkori temetője (The Middle Bronze Age cemetery of Biatorbágy-Szarvasugrás). In: Múltunk a föld alatt. Újabb régészeti kutatások Pest megyében (Our Past under Earth. Recent Archaeological Investigations In Pest County). Ed. A. Rajna. Szentendre 2014, 23-49, 170, 185-201.

= K. Marková: Zu den Bernsteinfunden aus Nitriansky Hrádok. In: Aktuelle Probleme der Erforschung der Frühbronzezeit in Böhmen und Mähren und in der Slowakei. Hrsg.: J. Bátora,

J. Peška. Archaeologica Slovaca monographiae - Communicationes 1. Nitra 1999, 211-229.

= E. F. MAYER: Die Äxte und Beile in Österreich. PBF IX/9. München 1977.

=W. MEIER-ARENDT (Hrsg.): Bronzezeit in Ungarn. Forschungen in Tell Siedlungen an Donau und Theiss. Frankfurt am Main 1992.

$=$ H. MELLER: Die neolithischen und bronzezeitlichen Goldfunde Mitteldeutschlands - Eine Übersicht. In: Metalle der Macht_Frühes Gold und Silber. 6. Mitteldeutscher Archäologentag vom 17. bis 19. Oktober 2013 in Halle (Saale). Tagungen des Landesmuseums für Vorgeschichte Halle 11. Eds: H. Meller, R. Risch, E. Pernicka. Halle/Saale 2014, 611-716.

$=$ H. Meller: Armies in the Early Bronze Age? An alternative interpretation of Únětice culture axe hoards. Antiquity 91 (2017) 1529-1545.

= E. Melis: Data on Early Bronze Age Apparel on the Basis of a Cremation Grave Excavated at Ménfőcsanak-Széles-földek. HungArch, 2013 Autumn.

= E. MeLIS: Analysis of secondary mortuary practices in the Early Bronze Age inhumation burials from North-Western Hungary. Musaica Archaeologica 2017 (1) 7-22.

$=\mathrm{E}$. MELIS: On the border of inhumation burial rite in the Early Bronze Age Northwestern Carpathian Basin (2000-1600 B.C.)? In: Tipping Point in the Bronze Age. Modes of change - inhumation versus cremation in Bronze Age burial rites. Ed.: O. Nakoinz. Kiel, in print.

= E. Melis: A nemi identitás kifejezésének vizsgálata a Nyugat-Dunántúl kora- és középső bronzkori csontvázas temetkezései körében (Analysis of expressing gender identity in the Early Bronze Age inhumation burials from Western Transadanubia). In: M $\mathrm{MO} \Sigma$ IX. A rituálé régészete. Öskoros Kutatók IX. Összejövetele tanulmánykötete. Ed.: P. Csengeri. Miskolc in print.

= E. MELIS: Adatok a többes és több fázisú csontvázas temetkezésekhez a középső bronzkori NyugatDunántúlon (Some remarks on the multiple and multi-phase burials of the Hungarian Middle Bronze Age in Western Transdanubia). In: Mikroszkóppal, feltárásokkal, mintavételezéssel, kutatásokkal az archeometria, a geoarcheológia és a régészet szolgálatában. Tanulmányok Ilon Gábor régész 60 éves születésnapi köszöntésére. Eds: L. Bartosiewicz, K. T. Biró, P. Sümegi, T. Törőcsik. Szeged in print.

= E. MELIS: Kora bronzkori településnyomok Enese-Pippani-dülő lelőhelyen (Early Bronze Age Settlement Traces at Enese-Pippani-dülő site). In: Évkönyv és jelentés a Magyar Nemzeti Múzeum, Nemzeti Örökségvédelmi Központ 2010. évi feltárásairól (Hungarian National Museum, National Heritage Protection Centre 2010 Yearbook and Review of archaeological investigations). Ed.: J. Kvassay. Budapest in print

= A. Mozsolics: Bronzefunde des Karpatenbeckens. Depotfundhorizonte von Hajdúsámson und Kosziderpadlás, Budapest 1967.

= M. NAGY: Der südlichste Fundort der Gáta-Wieselburg-Kultur in Zsennye-Kavicsbánya/Schottergrube, Komitat Vas, Westungarn. Savaria 36 (2013) 75-173.

= M. NAGY-A. FIGLER: Dentáliumékszerek a Gáta-Wieselburg kultúra temetkezéseiben (Dentalium jewellery in the burials of the Gáta-Wieselburg culture). In: M $\Omega M O \Sigma$ VI. Nyersanyagok és kereskedelem. Őskoros Kutatók VI. Összejövetelének konferenciakötete - Köszeg, 2009. március 19-21. Ed.: G. Ilon. Szombathely 255-266. 
NEUGEBAUER 1991

NEUGEBAUER 1994

Neugebauer-Maresch-Neugebauer 1989

Neugebauer-Maresch-Neugebauer 1997

Neugebauer-Maresch-Neugebauer 2001

NOTROFF 2011

NovotnÁ 1970

NOVOTNÁ 1984

OLEXA-GAŠAJ 1996

O'SHEA 1996

PATAY 2009

PICHLEROVÁ 1980

PRIMAS 1977

REBAY-SALISBURY in print

REIMER et al. 2013

RUCKDESCHEL 1979

RUTTKAY 1989

RUTTKAY 2002

SAUER et al. 2012

SAUER et al. 2013

SCHAUb 2009

SCHUBERT 1973
= J.-W. Neugebauer: Die Nekropole F von Gemeinlebarn, Niederösterreich. Untersuchungen zu den Bestattungssitten und zum Grabraub in der ausgehenden Frühbronzezeit in Niederösterreich südlich der Donau zwischen Enns und Wienerwald. Mainz am Rhein 1991.

= J-W. Neugebauer: Bronzezeit in Ostösterreich. St. Pölten-Wien 1994.

= C. Neugebauer-Maresch-J.-W. Neugebauer: Goldobjekte aus den Frühbronzezeitnekropolen Franzenhausen I und II und Gemeinlebarn F. MAGW 118/119 (1989) 101-134.

= C. Neugebauer-Maresch-J.-W. Neugebauer: Franzhausen das frühbronzezeitliche Gräberfeld I. FÖ Materialhefte A/5/1-2. Wien 1997.

= C. Neugebauer-Maresch-J.-W. Neugebauer: Zu den Bestattungssitten der endneolitischen Becherkulturen und der Frühbronzezeit Ostösterreichs - zum Forschungsstand. In: Mensch und Umwelt während des Neolithikums und der Frühbronzezeit in Mitteleuropa. Hrsg.: A. Lippert et al. IntArch 2. Rahden/Westf. 2001, 231-244.

$=\mathrm{J}$. NotROFF: Menace from the afterlife? Some remarks about the archaeological evidence for fearing and banishing the dead and contribution to Otomani and Füzesabony sepulchral rite. In: Bronze Age Rites and Rituals in the Carpathian Basin. Proceedings of the International Colloquium from Târgu Mureş 8-10 October 2010. Eds: S. Berecki, E. R. Németh, B. Rezi. Bibliotheca Musei Marisiensis. Seria archaeologica 4. Târgu Mureș 2011, 143-153.

= M. Novotná: Die Äxte und Beile in der Slowakei. PBF IX/3. München 1970.

= M. NovotnÁ: Halsringe und Diademe in der Slowakei. PBF XI/4. München 1984.

= L. OleXA-D. GAŠAJ: Nižná Myšla v dobe bronzovej - in der Bronzezeit. Nižná Myšla Fundplatz Várhegy Siedlungen und Gräberfeld aus der Bronzezeit. Ergebnisse der archäologischen Ausgrabungen 1977-1995. Blick auf die Geschichte des Ortes Nižná Myšla. Teil I. Košice 1996.

= J. M. O'SHEA: Villagers of the Maros. A Portrait of an Early Bronze Age Society. Interdisciplinary contributions to archaeology. New York-London 1996.

= R. PATAY: A Nagyrév-kultúra korai időszakának sírjai Szigetszentmiklósról (Burials of the early Nagyrév culture from Szigetszentmiklós). Tisicum 19 (2009) 209-227.

= M. Pichlerová: Praveké osídlenie Bratislavy-Rusoviec (Zur urzeitlichen Besiedlung von Bratislava-Rusovce). ZbSNM 74. Historia 20 (1980) 5-24, 35-37.

$=$ M. Primas: Untersuchungen zu den Bestattungssitten der ausgehenden Kupfer- und frühen Bronzezeit. BRGK 58 (1977) 4-106.

$=$ K. ReBAY-Salisbury: Personal relationships between co-buried individuals in the Central European Early Bronze Age. In: Giving New Meaning to Cultural Heritage. The Old and the Young in Past Societies. Eds: E. Murphy, G. Lillehammer. Stavanger: Museum of Archaeology, University of Stavanger/Society for the Study of Childhood in the Past. Oxford in print.

= P. J. Reimer-E. BARD-A. Bayliss-J. W. Beck-P. G. Blackwell-C. Bronk RAMSEY-C. E. BuckH. Cheng-R. L. Edwards-M. Friedrich-P. M. Grootes- T. P. Guilderson-H. HaflidasonI. Hajdas-C. Hatté-T. J. Heaton-D. L. Hoffmann-A. G. HogG-K. A. Hughen-K. F. KaiserB. Kromer-S. W. Manning-M. Niu-R. W. Reimer-D. A. Richards-E. M. ScotT-J. R. SouthonR. A. StafF-C. S. M. TuRneY-J. van DER Plicht: IntCal13 and Marine13 Radiocarbon Age Calibration Curves 0-50,000 Years cal BP. Radiocarbon 55 (2013) 1869-1887.

= W. RuCKDESCHEL: Die frühbronzezeitlichen Gräber Südbayerns. Ein Beitrag zur Kenntnis der Straubinger Kultur. Bonn 1979.

= E. RUTTKAY: Zwei verzierte Goldplättchen aus dem frühbronzezeitlichen Gräberfeld von HainburgTeichtal. MAGW 118-119 (1989) 135-145

= E. RutTKAY: Das endneolithische Hügelgrab von Neusiedl am See, Burgenland: zweite Vorlage. 1. Die Fazies Neusiedl (Egy későneolitikus halomsír Nezsiderből /Neusiedl am See, Burgenland/). BudRég 36 - In memoriam Rózsa Kalicz-Schreiber (1929-2001) (2002) 145-170.

= F. SAUER-N. Franz-J. SchwarzäUGL-A. TöGEL: KG Weiden am See, MG Weiden am See. FÖ 51 (2012) 170.

= F. SAuer-N. Franz-J. Schwarzäugl-A. Tögel: Weiden am See, MG Weiden am See. FÖ 52 (2013) 176-177.

$=\mathrm{H}$ : ScHAUB: Knochen und Bestattungssitten. Die Bedeutung archaologischer Funde zum Wiederganger- bzw. Vampirglauben, Kakanien Revisited 12, 2009 [online], Available at: http://www.kakanien.ac.at/beitr/vamp/HSchaub1.pdf [Accessed on 2013. január 8 /08 Januar 2013]

= E. SchuberT: Studien zur frühen Bronzezeit an der mittleren Donau. BRGK 54/1 (1968 [1973]) $3-105$. 
SCHUMACHER-MATTHÄUS 1985

SCHWARZ 2014

ŠEBELA 1999

SEBŐK et al. 2013

SHERRATT 1997

SOFAER-BUDDEN 2015

SosnA 2009

SøRENSEN-REBAY 2009

STOCKHAMMER et al. 2015

STUCHLÍK-STUCHLIKOVÁ 1996

V. SZABÓ 1997

V. SzABó 2004

SZATHMÁRI 1988

SZATHMÁRI 1996

SZATHMÁRI et al. in print

TEATHER-ChamberLain 2016

TOPÁL 1971

TOPÁL 1973

TORMA 1978

TóTH 1999

VANDKILDE 2005

VLADÁR 1973

VLADÁR 1974

WAGNER 2005

WEIHERMANN 2001
= G. SCHUMACHER-MatTHÄUS: Studien zu Bronzezeitlichen Schmucktrachten im Karpatenbecken. Ein Beitrag zur Deutung der Hortfunde im Karpatenbecken. Marburger Studien zur Vor- und Frühgeschichte 6. Mainz 1985.

$=$ R. SCHWARZ: Goldene Schläfen- und Lockenringe - Herrschaftsinsignien in bronzezeitlichen Ranggesellschaften Mitteldeutschlands. Überlegungen zur Gesellschaft der Aunjetitzer Kultur. In: Metalle der Macht. Frühes Gold und Silber. 6. Mitteldeutscher Archäologentag vom 17. bis 19. Oktober 2013 in Halle (Saale). Hrsg.: H. Meller, R. Risch, E. Pernicka. Tagungen des Landesmuseums für Vorgeschichte Halle 11. Halle/Saale 2014, 717-742.

= L. ŠEBElA: The Corded Ware Culture in Moravia and in the Adjacent Part of Silesia. A catalogue. Archeologický Ústav AV ČR, Brno 1999.

= K. SebőK-N. FARAgÓ-Zs. HaJdÚ-A. Anders-P. RACZKY-J. KovÁCs: Egy különleges kút és leletei Polgár-Csőszhalom késő neolitikus településről (An unusual well and its finds from the Late Neolithic settlement at Polgár-Csőszhalom). ArchÉrt 138 (2013) 29-79.

= A. SHERRATT: Economy and Society in Prehistoric Europe: Changing Perspectives. Edinburgh 1997.

$=$ J. SofAER-S. BudDEn: Many hands make light work. In: Embodied Knowledge. Perspectives on belief and technology. Eds: M. L Stig Sørensen, K. Rebay-Salisbury. Oxford 2015.

= D. SosnA: Social Differentiation in the Late Copper Age and the Early Bronze Age in South Moravia (Czech Republic). BAR, IntSer 1994. Oxford 2009.

$=$ M. L. S. SøRENSEN-K. REBAY: Landscapes of the body: Burials of the Middle Bronze Age in Hungary. EJA 11 (2009) 49-74.

= P. W. STOCKHAMMER-K. MASSY-C. KNIPPER-R. FRIEDRICH-B. KNOMER-R. LindAUER-J. RAdOSAVLJEVICF. WitTERborN-J. Krause: Rewriting the Central European Early Bronze Age Chronology: Evidence from Large-Scale Radiocarbon Dating. PloS One 10 (2015): e0139705.

= S. STUChLíK-J. StuCHLIKovÁ: Aunjetitzer Gräberfeld in Velké Pavlovice, Südmähren. PZ 71 (1996) 125-169.

= G. V. SzABÓ: A Perjámos-kultúra leletei Hódmezővásárhely környékén (Adalékok a kora és középső bronzkori női viselethez) [Findings of Perjamos culture in the Hódmezővásárhely region (Contribution to female costumes in the early and middle Bronze Age)]. In: Látták Trója kapuit. Bronzkori leletek a Közép-Tisza vidékéről. Ed.: P. Havassy. Gyulai katalógusok 3. Gyula 1997, 57-84.

= G. V. SzABÓ: A tiszacsegei edénydepó. Újabb adatok a Tisza-vidéki késő bronzkori edénydeponálás szokásához (Das Gefäßdepot von Tiszacsege. Neue Angaben zur Sitte der spätbronzezeitlichen Gefäßdeponierung in der Theißgegend). MFMÉ-StudArch 10 (2004) 81-113.

= I. SZATHMÁRI: Korai tütipusok a bronzkorban a Dunántúlon (Frühe Nadeltypen aus der Bronzezeit Transdanubiens). FolArch 39 (1988) 59-80.

= I. SZATHMÁRI: Bronze and wire sheet ornaments of the Vatya culture. In: Studien zur Metallindustrie im Karpatenbecken und den benachbarten Regionen. Ed.: T. Kovács. Budapest 1996, 75-88.

= I. SZATHMÁRI-B. MARÓTI-J. G. TARBAY-V. KISS: Archaeological and archaeometallurgical analyses of Bronze Age gold hair rings from the collection of the Hungarian National Museum and British Museum. In: Searching for Gold. International conference held in Vienna 9-10 June 2018. Eds: R. Jung, H. Popov. in print.

= A. Teather-A. Chamberlain: Dying embers: Fire-lighting technology and mortuary practice in Early Bronze Age Britain. AJ 173 (2016) 188-205.

= J. TopÁL: Bronzkori lemezdiadém Ócsáról (Bronze Age plate diadem from Ócsa). StComit 2 (1971) $3-11$.

= J. TOPÁL: Bronzkori ékszerlelet Ócsáról (A Bronze Age jewel find at Ócsa). ArchÉrt 100 (1973) 3-18.

= I. ToRmA: A balatonakali bronzkori sír (Das bronzezeitliche Grab in Balatonakali). VMMK 13 (1978) 15-27.

= K. То́тн: Kora bronzkori edénylelet Kecskemét-Csukáséren (Ein frühbronzezeitliches Gefässdepot auf dem Fundort Kecskemét-Csukásér). MFMÉ-StudArch 5 (1999) 27-49.

$=$ H. VANKILDE: A Biographical Perspective on Ösenringe from the Early Bronze Age. In: Die Dinge als Zeichen: Kulturelles Wissen und materieller Kultur. Internationale Fachtagung an der Johann Wolfgang Goethe-Universität, Frankfurt am Main 3.-5. April 2003. Ed. T. Kienlin. Universitätsforschungen zur prähistorischen Archäologie 125. Bonn 2005, 263-281.

= J. VLADÁR: Pohrebiská zo staršej doby bronzovej v Branči (Gräberfelder aus der älteren Bronzezeit in Branč). ASF 12. Bratislava 1973.

= J. VladÁR: Die Dolche in der Slowakei. PBF VI/3. München 1974.

$=\mathrm{J}$. WAGNER: Muster sozialer Differenzierung im frühbronzezeitlichen Gräberfeld von Mokrin/Vojvodina. MBGAEU 26 (2005) 111-146.

= J. WeIHERMAnN: Die goldenen Lockenringe der Bronzezeit. Einblicke in das frühe Goldschmiedehandwerk im Karpatenbecken. MBAEU 22 (2001) 167-181. 
ZOFFMANN 1999

ZOFFMANN 2008
= Zs. ZoFFMANN: A bronzkori Gáta-Wieselburg kultúra embertani leletei Hegyeshalom-Újtelep lelőhelyről (Die anthropologischen Funde der bronzezeitlichen Gáta-Wieselburg-Kultur vom Fundort Hegyeshalom-Újtelep). Arrabona 37 (1999) 65-82.

= Zs. ZoFFMANN: A bronzkori Gáta-Wieselburg kultúra Nagycenk-Laposi rét lelőhelyen feltárt temetkezéseinek embertani vizsgálata (The anthropologic study of the burials unearthed at the NagycenkLaposi rét site of the Bronze Age Gáta-Wieselburg culture). Arrabona 46 (2008) 9-34. 
